\title{
Direitos Humanos Sociais: NeCESSIDAde de PositivaÇão das REgRas de INTERPRETAÇÃO?
}

Tese de Doutorado apresentada ao Programa de PósGraduação em Direito da Universidade de São Paulo como requisito para a obtenção do grau de doutora em Direito, na área de Filosofia e Teoria Geral do Direito, sob orientação do Professor Titular Celso Lafer.

FACULDADE DE DIREITO DA UNIVERSIDADE DE SÃO PAULO SÃO PAULO 


\section{BANCA EXAMINADORA}

Prof. Titular Celso Lafer

Faculdade de Direito da Universidade São Paulo

Resultado:

São Paulo, de de 2009 
Dedico esse trabalho aos meus pais, Domiraide e Joaquim. Dedico também aos meus queridos filhos, Eduardo, Daniela e Ariel. 


\section{AGRADECIMENTOS}

Agradeço ao professor Celso Lafer a valiosa oportunidade que me concedeu, acolhendo-me como sua orientanda no curso de pós-graduação, proporcionandome uma orientação sempre esclarecedora, bem como à professora Elza Antonia Pereira Cunha Boiteaux pela solicitude com que sempre me atendeu.

A elaboração de uma tese de doutorado, desenvolvida ao longo de tantos anos, não poderia chegar a termo sem a colaboração de pessoas com quem conversamos e dialogamos nesse período. A todas elas, registro minha gratidão.

Agradeço a todos os meus familiares, em especial meus queridos pais, Joaquim e Domiraide, minhas irmãs, Fernanda e Heloisa, e meus filhos, Eduardo, Daniela e Ariel, que souberam compreender os meus momentos de ausência.

Agradeço ao meu marido Charles pela disponibilidade de cuidar de nosso filho, Ariel, enquanto eu me dedicava aos estudos, bem como pela forma crítica, exigente e criativa de analisar este trabalho.

Agradeço, especialmente, e de coração, a Rafael Prince Carneiro, assistente de pesquisa e companheiro de todas as horas no desenvolvimento desta empreitada, pela ajuda, colaboração, apoio e solidariedade em todos os momentos de dificuldades e incertezas que ocorreram nos anos finais deste projeto. Pela energia utópica transmitida em todos esses anos, nossos eternos agradecimentos. 
O problema dos direitos do homem, hoje, não é tanto o de justificá-los, mas o de protegêe-los. Trata-se de um problema não filosófico, mas político.

Norberto BOBBIO (A era dos direitos, p. 43) 
BARONGENO, Maria Cristina de Luca. Direitos Humanos Sociais: necessidade de positivação das regras de interpretação? 2009. 154 f. Tese (Doutorado em Filosofia e Teoria Geral do Direito) - Faculdade de Direito da Universidade de São Paulo, São Paulo, 2009.

\section{RESUMO}

Apesar do reconhecimento formal do princípio da dignidade humana e da formulação evidente dos direitos humanos sociais na Constituição brasileira, observamos, pela análise de casos levados ao Judiciário, que muitos magistrados ainda apresentam dificuldade para aplicar os princípios constitucionais. Esses princípios representam valores e, como tais, nem sempre se encontram totalmente internalizados na cultura do juízes. Além disso, as mensagens enviadas pelo sistema normativo dos direitos humanos sociais são diversas e antagônicas.

Esta tese constitui uma reflexão sobre o conhecimento prático das normas de direitos humanos sociais e sua aplicação concreta aos casos que se apresentam ao juiz no seu cotidiano. É um "parar para pensar" sobre o que estamos fazendo, por meio de um método experimental e de observação. Buscamos identificar os paradigmas do raciocínio jurídico desenvolvido pelos magistrados e seu impacto nas questões concernentes aos direitos sociais, apresentando proposta de um pequeno ajuste.

Lastreado na experiência de mais de quinze anos de exercício da magistratura, este trabalho tem um viés essencialmente empírico e, para tanto, utilizamos, sobretudo, fontes primárias - sentenças e acórdãos. Os casos apresentados foram selecionados em função do tipo e repetição do raciocínio do magistrado, a fim de possibilitar a identificação de aspectos comuns ao discurso decisório do judiciário brasileiro contemporâneo, registrando os seus acertos e desacertos, bem como suas implicações na concretização dos direitos humanos sociais.

A burocratização do Poder Judiciário vem desumanizando os magistrados, transformando-os em engrenagens necessárias à produção de sentenças. Dessa forma, passam a perder o dom da prudência e da paciência para sentir e compreender o Direito, bem como o dom da criatividade e da improvisação para bem aplicá-lo.

Para maximizar a efetividade concreta dos direitos sociais, concluímos não ser preciso nem conveniente positivar normas para guiar a interpretação. A solução que se mostra mais segura e eficaz seria que os juízes aprendessem a utilizar o silogismo - não da 
maneira que o queriam os postivistas, mas fundamentado nos princípios -- como um instrumento adequado para melhor concretização dos Direitos Humanos sociais.

Esse pequeno ajuste aproveita o Direto que possuímos, os magistrados que temos e a técnica de raciocínio que eles já vêm utilizando, além de constituir uma escolha consciente de espiritualizar o mundo e não mundanizar o espírito. Teríamos, assim, a oportunidade de vivenciar a Constituição Federal, que contém imperfeições, mas apresenta o grande mérito de estar impregnada de valores e de direitos conquistados arduamente ao longo da História.

Palavras-chave: Direitos humanos, hermenêutica, silogismo, princípios constitucionais 


\begin{abstract}
Despite the principle of human dignity being formally recognized by Brazilian Constitution, cases that come to the Courts show that many judges still have difficulties to apply constitutional principles. These principles represent values and, as so, they have sometimes not been internalized in the judges' culture. To make things worse, messages sent by the social human rights normative system are diverse and antagonic.

This thesis presents a reflexion about the practical knowledge of social human rights norms, an analysis of their daily appliance by judges. It represents, through an experimental and observational method, a pause to think about what we have been doing. Our aim is to identify the judges' legal reasoning paradigms and its impact on the actions that concern about social rights. In the end, we also suggest them a little adjustment.

Based on my fifteen-year experience as a judge, this work has an essencially empirical approach, making use of primary sources: judges' and Courts' decisions. Analyzed cases have been chosen for the type and repetition of the magistrates' reasoning. This method enables to identify the common aspects of Brazilian judges verdicts, recording their merits and mistakes, as well as their implication on the social human rights realization.

Bureaucratization of the judicial power has been depriving judges of their human spirit, turning them into verdict-producing gears. Therefore, they waste the virtues of prudence and patience, making it impossible for them to feel and understand the Law, as they lose creativity and improvisation to well apply it.

In order to maximize social rights effectivity, it is neither necessary nor convenient to write positive rules of interpretation. The most secure solution would be to teach judges how to use the syllogism - not in the way positivists preached, but rather guided by principles - as an adequate tool in order to make social human rights concrete.

The little adjustment we propose takes advantage of the Law we have, the judges we have and the argumentation method they have been using. It also represents a conscious choice to spiritualize the world rather than secularizing the spirit. We shall have then the opportunity to fully experience our Federal Constitution - which has many imperfections, but also has the great quality of safeguarding values and rights hardly conquered throughout History.
\end{abstract}

Keywords: Human rights, hermeneutics, syllogism, constitutional principles 


\section{RÉSUMÉ}

Malgré la reconaissance formelle du principe de la dignité humaine et de la formulation évidente des droits humains sociaux dans la Constituition brésilienne, nous observons, par l'analyse des cas portés au Judiciaire, que plusiers magistrats ont des difficultés d'appliquer les principes constitutionnaux. Comme ces principes sont guidés par des valeurs, ils ne sont pas toujours intériorisés par la culture des juges. En plus, les messages envoyés par le système normatif des droits humains sociaux sont divers et antagonistes.

Cette thèse constitue une réflexion sur la connaissance pratique des normes de droits humains sociaux et de son application concrete dans les cas qui se présentent au juge dans son quotidien. C'est une réflexion sur ce que nous faisons à travers d'une méthode expérimentale et d'observation. Nous cherchons a identifier les paradigmes du raisonnement juridique developé par les magistrats et son impact dans les questions concernants les droits sociaux, en présentant de plus une proposition d'un simple réglage.

Basé sur l'expérience de plus de quinze ans de l'exercice de la magistrature, ce travail a un bias essentiellement empirique et, dans ce cas, nous utilisont, surtout, des sources primaires - sentences et verdicts. Les cas presentés ont été selectionés en fonction $\mathrm{du}$ type et de la répétition du raisonnement du magistrat, en rendant possible l'identification des aspects communs du discours de décision du judiciaire brésilien contemporain, en registrant les reussites et les échecs, ainsi comme ses implications dans la matérialisation des droits humains sociaux.

L'excess de bureaucratisation du pouvoir judiciaire est en train de déshumaniser les magistrats en les transformant en engrenages nécessaires à la production des sentences. De cette forme, ils sont en train de perdre le don de la prudence e de la patience nécessaire a bien sentir et comprendre le droit, ainsi comme le don de la créativité e de la improvisation pour mieux l'appliquer.

Pour augumenter l'effectivité concrète des droits sociaux, ce n'est pas nécessaire ni convenable de rendre efficace les règles pour guider l'interprétation. La solution qui se montre la plus sûre et efficace serait que les juges apprennent à utiliser le syllogisme - pas de la façon envisagée par les positivistes, mais plutôt par celle fondée sur les principes - comme un instrument adapté pour la meilleure matérialisation des droits humains sociaux. 
Ce simple ajustement tire profit du droit que nous possédons, des magistrats que nous avons, et de la technique de raisonnemente qu'ils utilisent dejá, et en plus il constitue un choix conscient de spiritualiser le monde et non pas tourner mondain l'esprit. Nous aurions, ainsi, l'opportunité d'être en contact avec la Constituition Fédérale qui contient des imperfections, mais présente le grand mérite d'être imprégné des valeurs et des droits conquis durement au cours de l'Histoire.

Mots-clés: Droits de l'homme, herméneutique, syllogisme, principes contitutionnels 


\section{LISTA DE SIGLAS E ABREVIATURAS}

AC: Apelação Criminal

ADI: Ação Direta de Inconstitucionalidade

ADPF: Arguição de Descumprimento de Preceito Fundamental

AgReg: Agravo Regimental

Art.: Artigo

CF: Constituição Federal

DJ: Diário da Justiça

HC: Habeas Corpus

IPC: Instituto de Previdência dos Congressistas

Min.: Ministro

ONU: Organização das Nações Unidas

Pet: Petição

RE: Recurso Extraordinário

REsp: Recurso Especial

Rel.: Relator

STJ: Superior Tribunal de Justiça

STF: Supremo Tribunal Federal

TRF: Tribunal Regional Federal 


\section{SUMÁRIO}

1. INTRODUÇÃO

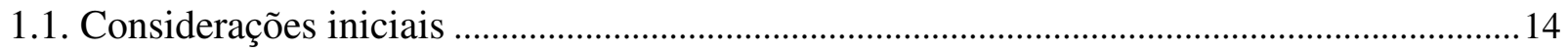

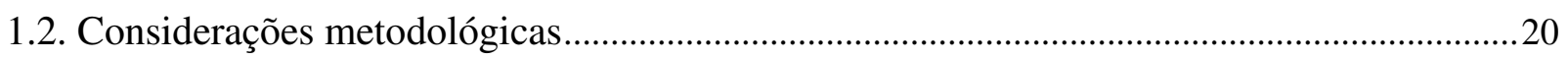

2. “A HISTÓRIA DE UM COMBATE” …...............................................................................22

2.1. Natureza histórica e conflituosa dos direitos humanos ............................................................22

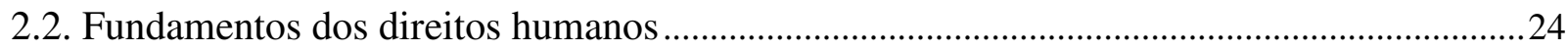

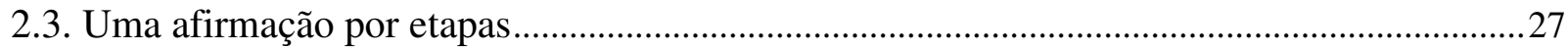

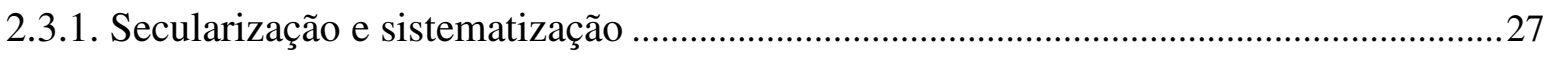

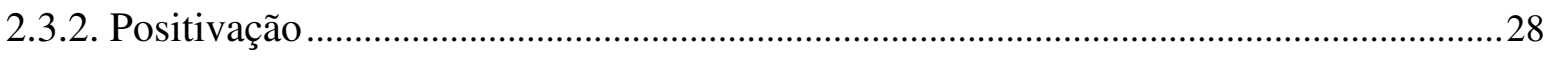

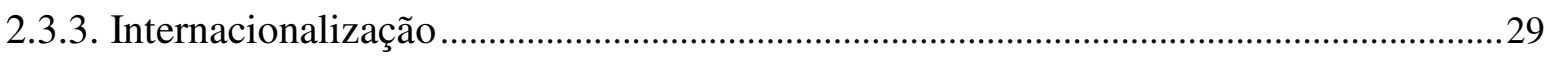

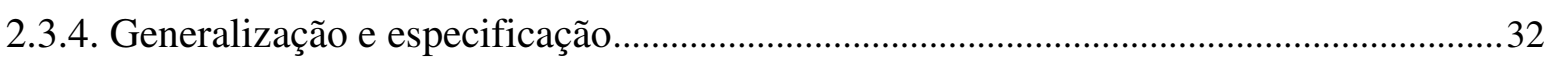

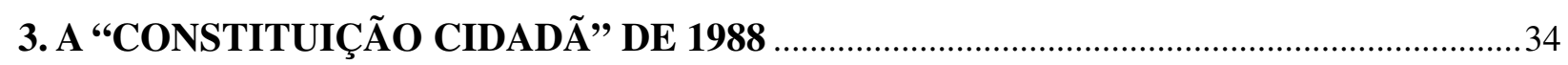

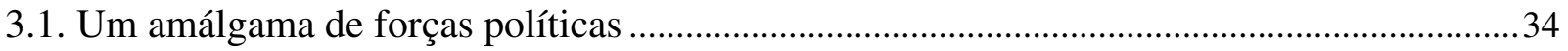

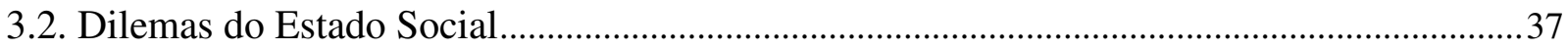

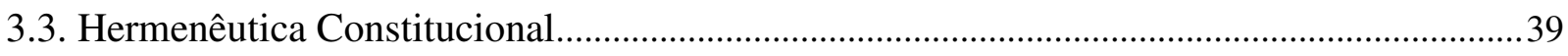

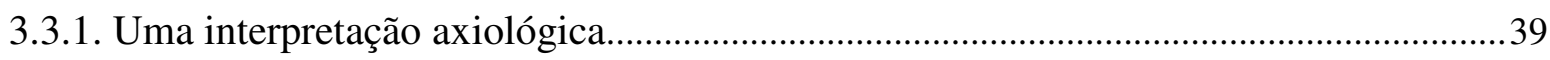

3.3.2. História dos métodos hermenêuticos: do Estado de Direito ao Estado Social ..............43

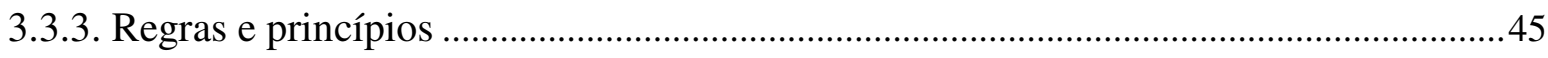

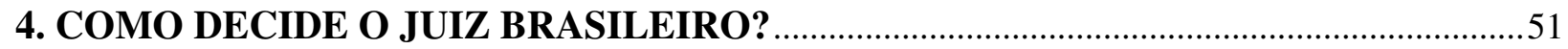

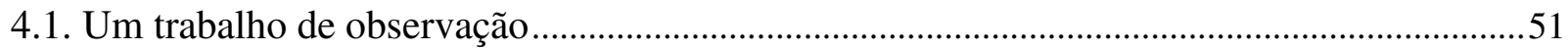

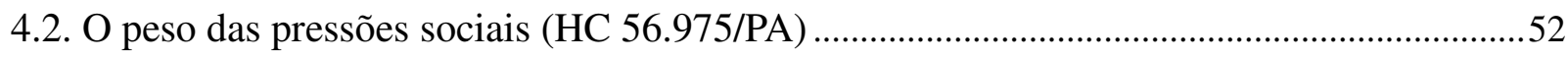

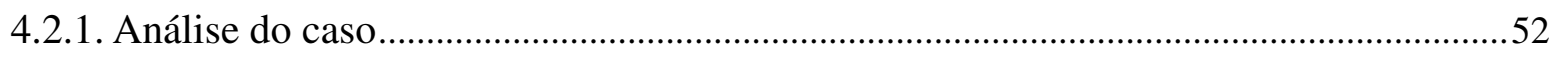

4.2.2. Silogismo revisitado: por um silogismo crítico e axiológico ..........................................57

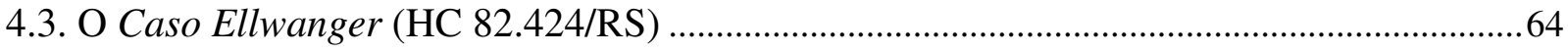

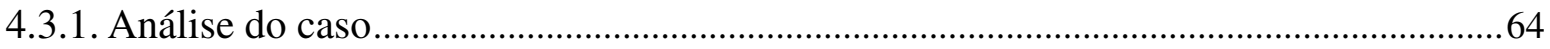

4.3.2. A correta assunção do princípio constitucional como premissa maior ...........................71

4.3.3. A busca dialética pela premissa menor (qualificação jurídica) ……................................73

4.4. O silogismo no jogo dialético (HC 34.987 - RJ) ..................................................................75 
4.5. Uma invariante axiológica inata (AC 19059 no TRF da $3^{\text {a }}$ Região) 78

4.5.1. Análise do caso. .78

4.5.2. A facilidade com que se aplica o princípio da legalidade............................................... 82

4.6. A supremacia da constituição: uma tecnologia em construção (HC 44.165/RS)...................84

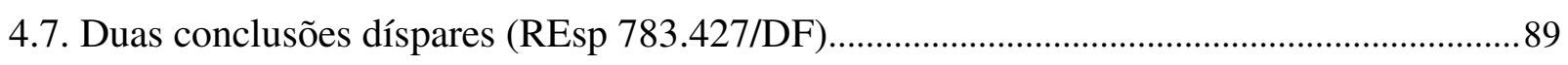

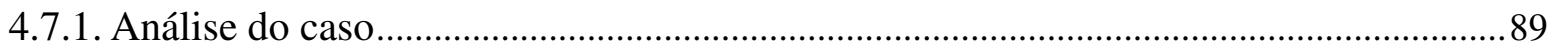

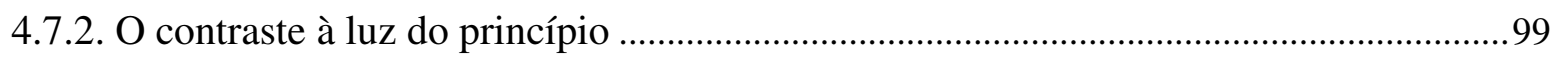

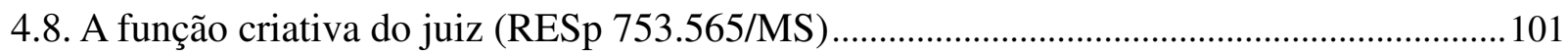

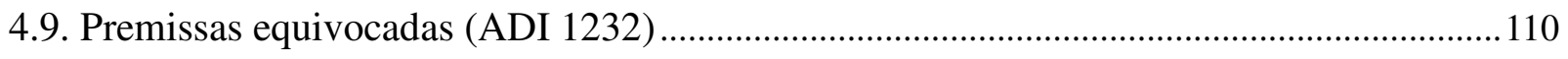

4.10. O Judiciário e o Direito à Saúde (Agravo de Instrumento no RE 393.175/RS e ADPF 45)

5. CONCLUSÕES 127

5.1. O direito brasileiro 127

5.2. Os juízes . 130

5.3. O ambiente 133

5.4. A compreensão do direito. 135

5.5. Análise dos casos concretos 136

5.6. $\mathrm{O}$ valor 138

5.7. Expectativas sociais 140

5.8. Um pequeno ajuste. 140 


\section{INTRODUÇÃO}

\subsection{Considerações iniciais}

É uma tarefa árdua trazer algo de novo a um tema tão em voga como o dos direitos sociais. Muito se tem escrito sobre sua aplicação, mesmo assim, grande parte das publicações nacionais em nada inovam, limitando-se a repetir os clássicos, os estrangeiros e seus conceitos.

Não nos atribuímos um grande espírito criador, tampouco somos portadores de ideias revolucionárias. A pequena contribuição que pretendemos tributar à doutrina jurídica brasileira se resume a um estudo empírico, à análise da aplicação dos direitos sociais em casos concretos e do pensamento paradigmático dos juízes. Temos, como propósito, analisar a forma de pensar dos juízes, para, assim, diagnosticar qual o problema que impede a plena realização dos direitos humanos sociais.

Esse é o tributo que está a nosso alcance, após mais de uma década de exercício da judicatura. Não nos aprofundaremos - à maneira do ouriço ${ }^{1}$ - nas questões teóricas relativas aos direitos humanos. Ao contrário - e à semelhança da raposa procuraremos uma abordagem mais plural, afeita à complexidade da vida e aos diversos fatores que moldam o raciocínio decisório do juiz.

Nossa tese tem, destarte, o intuito de contribuir para sanear o modus operandi do pensamento do magistrado e, assim, contribuir com a realização dos direitos humanos sociais e de uma sociedade livre, justa e solidária. Essa modesta colaboração é fruto de anos de observação e da crença de que algumas pequenas, sutis e precisas

\footnotetext{
1“Muitas coisas sabe a raposa, mas o ouriço uma grande é um verso do poeta grego Arquíloco a partir do qual Isaiah Berlin propôs um critério para classificar escritores e pensadores, diferenciando-os a partir de certos traços definidores de suas obras. Existem, observa ele, os que relacionam tudo a uma visão unitária e coerente, que funciona como um princípio organizador básico do que pensam e percebem. São os ouriços, que articulam uma visão centrípeta e monista da realidade. Outros, ao contrário, se interessam por várias coisas, perseguem vários fins e objetivos - por vezes não relacionados ou até mesmo contraditórios - cuja interconexão não é nem óbvia nem explícita. São as raposas, que dessa maneira exprimem uma perspectiva centrífuga e pluralista da realidade" (LAFER, Celso. A reconstrução dos direitos humanos: um diálogo com o pensamento de Hannah Arendt. 4. ed. São Paulo: Companhia das Letras, 2001. p. 13).
} 
intervenções $^{2}$ podem ajudar a organizar o raciocínio dos magistrados, que muitas vezes se perde nas brumas da confusão.

A dignidade da pessoa humana ${ }^{3}$ é considerada hoje um princípio geral de direito para todos os povos civilizados ${ }^{4}$, e o Estado brasileiro o encampa, tanto na esfera internacional quanto na esfera interna, fato que se depreende da simples leitura da própria Constituição da República ${ }^{5}$, dos tratados internacionais ratificados pelo Brasil ${ }^{6}$ e das leis específicas $^{7}$. Apesar do reconhecimento desse princípio e da formulação evidente das pretensões do Estado brasileiro a garantir e proteger os direitos humanos, observamos, pela análise de casos concretos, que essa proteção, muitas vezes, tem se resumido à edição de

${ }^{2} \mathrm{O}$ direito, tal qual o mito (quem conta um conto, aumenta um ponto), evolui mediante "mudanças conservadoras", lentas e graduais (GRÄZIN, Igor. Law is myth. International Journal for the Semiotics of Law, Holanda, v. 18, n. 1, p. 23-51, Mar. 2005). O direito, como discurso social, é recontado a cada vez que é aplicado - imperativo da segurança da sociedade, cujos membros desejam ter suas expectativas atendidas (FERRAZ JUNIOR, Tércio Sampaio. Introdução ao estudo do direito: técnica, decisão, dominação. 4. ed. São Paulo: Atlas, 2003. p. 102-103). Se não acompanhasse as mudanças da sociedade, poderia ser representado como uma circunferência que sempre se desenha em torno do mesmo ponto. Mas a cada vez que é recontado, o direito também é reinventado. A história de sua evolução contínua, lenta e gradual pode ser representada como uma espiral, na qual cada inovação afasta a curva do centro original.

${ }^{3}$ Em que pese a dificuldade e as controvérsias acerca de sua definição - terreno pantanoso no qual não ousamos nos aventurar -, a dignidade é passível de uma certa delimitação semântica em suas diversas dimensões. Sob o prisma ontológico, relaciona-se à própria condição inerente do ser humano, como valor absoluto. No âmbito inter-relacional, a dignidade está conectada ao reconhecimento pelo outro como um igual. Já uma perspectiva histórico-cultural não pode deixar de considerar que a dignidade, por ser uma categoria axiológica aberta, construída e não dada, é um conceito em permanente processo de construção e desenvolvimento. Cf. SARLET, Ingo Wolfgang. As dimensões da dignidade da pessoa humana: construindo uma compreensão jurídico-constitucional necessária e possível. Revista Brasileira de Direito Constitucional, São Paulo, n. 9, p. 361-388, jan./jul. 2007.

4"A dignidade humana constitui valor fundamental da ordem jurídica para a ordem constitucional que pretenda se apresentar como Estado democrático de direito" (SARLET, Ingo Wolfgang. Dignidade da pessoa humana e direitos fundamentais na Constituição Federal de 1988. Porto Alegre: Livraria do Advogado, 2001. p. 37).

${ }^{5}$ A dignidade da pessoa humana, logo no primeiro artigo da Constituição Federal (CF), figura entre os fundamentos da República Federativa do Brasil (CF, Art. $1^{\circ}$, inciso III).

${ }^{6}$ A Constituição Federal de 1988 busca privilegiar o importante papel da internacionalização dos direitos humanos, sobre a qual discorreremos a seguir. Cabe lembrar a redação do §2 $2^{\circ}$ do artigo $5^{\circ}$ : "Os direitos e garantias expressos nesta Constituição não excluem outros decorrentes do regime e dos princípios por ela adotados, ou dos tratados internacionais em que a República Federativa do Brasil seja parte”. O parágrafo seguinte $\left(\$ 3^{\circ}\right)$ prevê status de Emenda Constitucional aos tratados internacionais que se submeterem ao procedimento nele previsto (maioria qualificada de três quintos em cada casas do Congresso Nacional, em dois turnos de votação). Devemos, ainda, lembrar o recente entendimento do Supremo Tribunal Federal conforme o voto do ministro Gilmar Mendes no RE 466.343-SP) - acerca do status supralegal dos tratados que não se submeterem àquele processo.

${ }^{7}$ Embora, muitas vezes, a legislação infraconstitucional pretenda limitar o alcance das normas constitucionais. Esse é precisamente o caso da Lei de Organização da Assistência Social (Lei 8.742/93), a qual, no parágrafo terceiro de seu artigo 20, especifica que a condição de "subsistência" é atingida quando a família do idoso ou do deficiente tenha renda familiar per capita superior a 1/4 de salário mínimo. A fixação arbitrária de um limite tão baixo pelo legislador limita em muito o alcance da norma contida no inciso IV do artigo 203 da Constituição Federal. O julgamento da ADI 1.232-DF, que justamente questionava esse asssunto, será objeto de análise mais adiante. 
normas abstratas. Embora escritas com clareza, tais normas se tornam confusas e vagas no momento de passar da hipótese estabelecida no texto para sua aplicação concreta.

Sabemos que o reconhecimento formal dos direitos humanos sociais pelo ordenamento jurídico de nada vale se estes não se tornarem efetivos. Conhecemos também a crise do Estado social, fruto da hiperjuridificação ${ }^{8}$ da sociedade produzida pelo intervencionismo normativo ${ }^{9}$ e da "incapacidade do Estado e de seus instrumentos formais para dar conta do aumento incontrolável das demandas sociais." 10

Vivemos uma verdadeira inflação legislativa, fruto da crença de que todos os problemas da sociedade - dos mais graves aos mais singelos - podem se resolver com a criação de novas leis ou com a alteração das existentes. Dessa maneira, surgem diplomas legislativos ao sabor dos ventos, geralmente se apresentando incompletos, paradoxais ou confusos. Ao magistrado, cabe a tarefa hercúlea ${ }^{11}$ de costurar a enorme colcha de retalhos em que se transformou o sistema jurídico nacional.

No que diz respeito aos direitos humanos sociais, a realidade jurídica é a mesma, com um obstáculo adicional: são preceitos dirigidos a uma prestação positiva do Estado (ou seja, criam uma espécie de "crédito do indivíduo perante o a sociedade") ${ }^{12}$

\footnotetext{
${ }^{8}$ A hiperjuridificação é resultado do malabarismo que devem fazer os legisladores do Estado Social para atender os anseios, de um lado, das massas populares e, de outro, dos investidores privados, bem como da ilusão de segurança que os textos legais produzem em uma sociedade carente de energias utópicas. Cf. HABERMAS, Jürgen. A nova intransparência: a crise do estado do bem - estar social e o esgotamento das snergias utópicas. São Paulo: Centro Brasiliense de Análise e Planejamento, 1987. (Novos Estudos, n. 18).

9"Em matéria de legislação, por exemplo, vivencia-se verdadeira compulsão, motivadora do fenômeno denominado 'inflação legislativa', estruturada na falsa premissa de que todos os problemas, dos mais graves aos mais banais, se resolvem com uma simples mudança das leis, revelando-se esforço inútil e desnecessário, desprovidos de qualquer efeito concreto. Sucedem-se, pois, diplomas legislativos ao sabor dos ventos, incompletos, paradoxais, confusos, exigindo infinita confrontação com a legislação preexistente, pinçando-se aqui e ali o que foi revogado e o que ainda prevalece no ordenamento jurídico". (FANTONI JÚNIOR, Neyton. Segurança jurídica e interpretação constitucional. Genesis: revista de direito do trabalho, Curitiba, n. 84, p. 847, dez. 1999).

${ }^{10}$ MURICY, Marília. Racionalidade do direito, justiça e interpretação: diálogo entre a teoria pura e a concepção luhmanniana do direito como sistema autopoiético. In: BOUCAULT, Carlos E. de Abreu; RODRIGUEZ, José Rodrigo (Orgs.). Hermenêutica plural: possibilidades jusfilosóficas em contextos imperfeitos. São Paulo: Martins Fontes, 2002. p. 110.

${ }^{11}$ Não é à toa que Ronald Dworkin recorre à imagem do mítico herói grego para designar um juiz ideal, prudente, sábio e capaz de chegar à decisão correta de um caso difícil (cf. DWORKIN, Ronald. Law's empire. Harvard Cambridge, Massachussets: Harvard University Press, 1988). Não compartilhamos com o jurista americano o arquétipo de Hércules - o juiz ideal do Estado Social, tampouco sustentamos a figura de Júpiter, como queriam os ideólogos do Estado Liberal. Cremos em uma terceira figura, o juiz Hermes, ladino e criativo, pois só assim saberá lidar com as demandas contraditórias da contemporaneidade. Infelizmente, todos esses tipos ideais estão muito distantes da realidade dos tribunais brasileiros. Essa metáfora e esses arquétipos, aos quais retornaremos, são bem trabalhados por François Ost (OST, François. Júpiter, Hércules, Hermes: três modelos de juez. Trad. Isabel Lifante Vidal. Doxa: Cuadernos de filosofía del derecho, n. 14, p. 169-194, 1993).

${ }^{12}$ "É por essa razão que os assim chamados direitos de segunda geração, previstos pelo 'welfare state', são direitos de crédito do indivíduo em relação à coletividade. Tais direitos - como o direito ao trabalho, à saúde, à educação - têm como sujeito passivo o Estado porque, na interação entre governantes e governados, foi a coletividade que assumiu a responsabilidade de atendê-los." (LAFER, op. cit., p. 127).
} 
obrigando-o a criar condições objetivas que propiciem ao titular o exercício do direito não se fazem imediatamente realizáveis, embora desde logo exigíveis ${ }^{13}$. Ressalta-se, destarte, a importância do papel do Poder Judiciário na concretização e proteção desses direitos, bem como na materialização do princípio constitucional discutido no caso concreto $^{14}$.

Observamos que os direitos sociais constantes de todas as declarações nacionais e internacionais têm permanecido no papel. O problema fundamental em relação aos direitos humanos não é tanto o de justificá-los, mas o de aplicá-los ${ }^{15}$. De fato, os direitos humanos são valores positivados na ordem jurídica brasileira, necessitando que os magistrados criem o hábito ${ }^{16}$ de aplicá-los no cotidiano.

No exercício da judicatura, defrontamo-nos com diversas ações civis ajuizadas pelo Ministério Público para a salvaguarda dos direitos humanos denominados “de segunda geração" "17. Tivemos a oportunidade de perceber que a eficácia desses direitos não depende apenas da sua positivação em textos legais, mas exige do juiz, ao ser chamado a ampará-los e socorrê-los, que o faça com a mesma facilidade que garante, quando colocados em perigo, os direitos individuais (“direitos humanos de primeira geração”) -como o direito à intimidade, à propriedade, à liberdade, à vida privada, à saúde individual, ao sigilo bancário -- ou mesmo os direitos do consumidor, do trabalhador e do contribuinte.

\footnotetext{
${ }^{13}$ Está superada a concepção de noras constitucionais meramente programáticas (diretivas) ou de eficácia limitada. Canotilho proclama a "morte das normas progrmáticas", afirmando que qualquer norma constitucional deve considerar-se obrigatória perante quaisquer órgãos do poder político". (CANOTILHO, Joaquim José Gomes. Direito constitucional e teoria da Constituição. 2. ed. Coimbra: Almedina, 2001. p. 1102).

${ }^{14}$ Cada vez mais, o próprio Judiciário se faz ciente desse seu papel, conforme podemos observar na ementa do Agravo Regimental (AgReg) no Recurso Extraordinário (RE), do qual foi relator $\mathrm{n}^{\circ} 410715 / \mathrm{SP}$ o ministro Celso de Mello: "Embora resida, primariamente, nos Poderes Legislativo e Executivo, a prerrogativa de formular e executar políticas públicas, revela-se possível, no entanto, ao Poder Judiciário, determinar, ainda que em bases excepcionais, especialmente nas hipóteses de políticas públicas definidas pela própria Constituição, sejam estas implementadas pelos órgãos estatais inadimplentes, cuja omissão por importar em descumprimento dos encargos político-jurídicos que sobre eles incidem em caráter mandatório - mostra-se apta a comprometer a eficácia e a integridade de direitos sociais e culturais impregnados de estatura constitucional." (AgReg no RE n ${ }^{\circ}$ 410715/SP, $2^{\text {a }}$ Turma, Rel. Min. CELSO DE MELLO, DJ de 03/02/2006).

${ }^{15}$ BOBBIO, Norberto. A era dos direitos. Trad. Regina Lyra. Rio de Janeiro: Campus, 1992. p. 43.

${ }^{16}$ ARISTÓTELES. Ética a Nicômaco. Trad. de Edson Bini. São Paulo: Edipro, 2002. p. 62.

${ }^{17}$ “O elenco dos direitos humanos contemplados pelo Direito Positivo foi se alterando do século XVIII até os nossos dias. Assim caminhou-se historicamente dos direitos humanos de primeira geração - os direitos civis e políticos de garantia, de cunho individualista voltados para tutelar a diferença entre Estado e Sociedade e impedir a dissolução do indivíduo num todo coletivo - para os direitos de segunda geração os direitos econômicos, sociais e culturais concebidos como créditos dos indivíduos com relação à sociedade, a serem saldados pelo Estado em nome da comunidade nacional. O processo de asserção histórica das duas gerações de direitos humanos, que são direitos de titularidade individual, foi inspirado pelos legados cosmopolita e universalista do liberalismo e do socialismo." (LAFER, Celso. A reconstrução dos direitos humanos: a contribuição de Hannah Arendt. Estudos Avançados, São Paulo, v. 11, n. 30, p. 57, 1997. [Dossiê Direitos Humanos]).
} 
Não ignoramos que a eficácia dos direitos humanos de segunda geração é comprometida por diversas outras questões, além do papel desempenhado pelo Poder Judiciário: o caráter reducionista da legislação infraconstitucional que trata do assunto, atos administrativos de duvidosa legalidade, ou mesmo a falta de instituições, regras de procedimento e homens animados pela cultura de protegê-los ${ }^{18}$. Todavia, a abrangência de nossos estudos ficará restrita à análise crítica dos métodos de raciocínio e interpretação utilizados pelos magistrados na aplicação dessas normas, bem como ao questionamento de sua atuação como método adequado à proteção desses direitos.

O magistrado brasileiro, na tarefa de concretizar os direitos humanos sociais, deve aceitar a sua condição de prático e não de teórico do direito, seguindo sempre uma interpretação funcional, que sirva para implantar a paz entre os homens. O homem prático age guiado pelo resultado concreto, jamais pela especulação inquisitiva ${ }^{19}$. O juiz, não deve questionar os pontos de partida - no caso, as normas constitucionais sobre direitos sociais - mas aplicá-los da maneira mais prudente. De nada adianta que, ao ser chamado para aplicar o direito, o juiz redija um completíssimo tratado sobre a questão em pauta, ou que demonstre pleno conhecimento teórico dos direitos do homem ${ }^{20}$, se não é capaz de realizá-los.

"Entre os juízes brasileiros, via de regra, abusa-se das citações. Por dá cá
aquela palha, invocam-se profusamente autores e precedentes julgados,
daquém e além mar, com transcrições em sete línguas diferentes, e as
sentenças fogem inteiramente, por isso mesmo, à austera singeleza de que
devem revestir-se. Como adverte CALAMANDREI, no seu Elogio dos
Juízes, as sentenças judiciais não precisam de ser amostras de rebrilhante
cultura de vitrina. O que lhes convém é que, dentro das possibilidades
humanas, sejam justas, servindo ao fim prático de implantar a paz entre
os homens. Longe de mim afirmar que o juiz não deva ilustrar-se,
consultando a lição doutrinárias e pondo-se em dia com a evolução

${ }^{18}$ Cf. FARIA, José Eduardo. O Direito na Economia Globalizada. São Paulo: Malheiros, 2000.

19،[...] usando uma terminologia de Viehweg, temos um enfoque zetético e [...] um enfoque dogmático. Zetética vem de zeteinm que significa perquirir, dogmática vem de dokein, que significa ensinar, doutrinar. Embora entre ambas não haja uma linha divisória radical (toda investigação acentua mais um enfoque que o outro, mas sempre tem os dois), sua diferença é importante. O enfoque dogmático releva o ato de opinar e ressalva algumas das opiniões. O zetético, ao contrário, desintegra, dissolve as opiniões, pondo-as em dúvida. Questões zetéticas têm uma função especulativa explícita e são infinitas. Questões dogmáticas têm uma função diretiva explícita e são finitas. Nas primeiras, o problema tematizado é configurado como um ser (o que é algo?). Nas segundas, a situação nelas captada configura-se como um dever-ser (como deve ser algo?). Por isso, o enfoque zetético visa saber o que é uma coisa. Já o enfoque dogmático preocupa-se em possibilitar uma decisão e orientar a ação. (FERRAZ JUNIOR, Tércio Sampaio. op. cit., p. 41).

${ }^{20} \mathrm{~A}$ escolha de palavras jamais é neutra (LOCHAK, Danièle. Les droits de l'homme. Paris: La Découverte: 2005. p. 6) mas usaremos, ao longo deste trabalho, de maneira intercambiável, as expressões "direitos humanos" e "direitos do homem" - correspondente a primeira à tradição anglófona e a segunda à francófona - conforme o uso corrente na literatura especializada, nos tratados internacionais e na legislação brasileira. 
jurídica; mas se ele se deixa seduzir demasiadamente pelo teorismo, vai dar no carrascal das subtilitates juris e das abstrações inanes, distanciando-se do solo firma dos fatos, para aplicar, não a autêntica justiça, que é sentimento em face da vida, mas um direito cerebrino e inumano, não o direito como ciência da vida social, mas o direito como ciência de lógica pura, divorciado da realidade humana, não a verdadeira justiça, que é função da alma voltada para o mundo, mas um direito postiço, arrebicado, sabendo a palha seca e cheirando a naftalina de biblioteca. O juiz que, para a demonstração de ser a linha reta o caminho mais curto entre dois pontos, cita desde Euclides até os geômetras da quarta dimensão, acaba perdendo a crença em si mesmo e a coragem de pensar por conta própria. Dele jamais se poderá esperar uma solução cautamente preotiana, um milímetro de avanço na evolução do direito, o mais insignificante esforço de adaptação das leis."21

Poderíamos comparar o papel do juiz àquele desempenhado pelo mecânico de automóveis. O veículo de determinado cliente chega à sua oficina conduzido por um guincho, porque parou de funcionar, ou apresenta problema grave que ameaça seu funcionamento. Espera-se que o mecânico neutralize, de alguma forma, a paralisação efetiva ou potencial do veículo e devolva o carro em adequadas condições de uso. Se o carro é muito antigo, encontra-se em mal estado de conservação, se o cliente está com muita pressa, precisa do carro com urgência, ou mesmo não tem recursos para grandes reparos, o mecânico pode apostar em uma gambiarra, que ensejará reparos posteriores. Porém, em hipótese alguma, é-lhe facultado devolver o carro sem funcionar. Da mesma forma, no processo decisório e dogmático do direito, é vedado ao juiz pronunciar um non liquet, ou seja, deixar de decidir.

"O direito parece ser um fenômeno delimitado por duas exigências incontornáveis: a da inegabilidade dos pontos de partida e a da proibição do non liquet. Contudo, somente o caráter compulsório da decisão é realmente imprescindível ao direito. Os pontos de partida só não são geralmente negados em virtude da implacabilidade da obrigação de julgar, pois, caso não existisse uma primacial necessidade de decidir as demandas judiciais, poder-se-ia freqüentemente negá-los, sem maiores problemas. No processo de evolução do direito, muitos pontos de partida foram (e continuam sendo) negados e, ainda assim, o dever de decidir permanece intacto.

A atividade judiciária envolve o processo hermenêutico. Uma interpretação mantida em aberto, ou seja, desprovida da necessidade de encontrar elementos jurídicos capazes de solucionar os conflitos, advindos da convivência social e relevantes para o direito, converter-se-ia em interminável discussão. Depois de observado o devido trâmite judiciário, é indispensável a ocorrência de uma decisão jurídica definitiva, asseguradora de

\footnotetext{
${ }^{21}$ HUNGRIA, Nelson. Comentários ao Código Penal. Rio de Janeiro: Edições Revista Forense, 1955. v. 1, t. 1, p. 62 .
} 
que a interpretação terá fim, impedindo a indefinição em relação ao direito postulado em juízo.

A obrigação de julgar as demandas é intrínseca ao fenômeno jurídico, "ainda que nada tenha ficado provado; ainda que quem decida não saiba quem tem razão; ainda que não saiba qual das partes é a vítima e qual o algoz; ainda que ignore qual das partes o está enganando", persistirá o dever de resolver a contenda sob a responsabilidade judicial; embora não saiba claramente, deve julgar como se soubesse. A apresentação de uma solução para o litígio é indispensável para a realização do direito." 22

Ao decidir um caso levado à sua apreciação, espera-se do magistrado que pratique aquilo que Aristóteles designava por phronesis e a que os romanos chamaram de prudentia: a virtude que dispõe a razão prática a discernir em qualquer circunstância o nosso verdadeiro bem e escolher os justos meios para o atingir. Infelizmente, a realidade brasileira atual está longe desse ideal, mas buscaremos entender a forma de pensar do juiz para colaborar com o resgate da velha prudência romana.

\subsection{Considerações metodológicas}

Ao começarmos nossa pesquisa, trabalhávamos com a hipótese de que a ausência de regras positivas de interpretação - tal qual ocorre em outros ramos do direito (penal, trabalhista, consumerista, etc.) - seria a principal razão para a falta de efetividade dos direitos humanos sociais no Brasil. Contudo, a análise dos casos nos mostrou que o mais grave problema é, na verdade, a forma de raciocinar do magistrado brasileiro. Desta maneira, oportunamente, trocamos o tom afirmativo do título desta tese (Direitos Humanos Sociais: necessidade das regras de positivação), por um tom questionador (Direitos Humanos Sociais: necessidade das regras de positivação?).

Este trabalho traz, portanto, uma reflexão sobre o conhecimento prático das normas do direito positivo e sua aplicação concreta aos casos que se apresentam ao juiz no cotidiano. É um parar para pensar sobre o que estamos fazendo ${ }^{23}$, por meio de um método experimental e de observação, a fim de identificar os paradigmas do raciocínio jurídico

\footnotetext{
${ }^{22}$ CASTRO FILHO, Osvaldo Alves de. A obrigatoriedade da decisão no direito: subsídios para a elaboração de uma teoria da decisão jurídica. Dissertação (Mestrado em Filosofia e Teoria Geral do Direito) Faculdade de Direito, Universidade de São Paulo, São Paulo, 2007. p. 16.

${ }^{23}$ ARENDT, Hannah. A condição humana. 10. ed. Tradução de Roberto Raposo Rio de Janeiro: Forense, 2005. p. 13.
} 
desenvolvido pelos magistrados e seu impacto nas questões envolvendo direitos sociais. $\mathrm{Na}$ verdade, o espírito humano cultiva ciência e arte, pratica atos de moralidade e de religião, mas somente na filosofia podemos meditar sobre o sentido e alcance dessas atividades. Nas palavras de Aristóteles, experiência e pensamento constituem as fontes de todo o conhecer ${ }^{24}$.

Vamos nos sentar em posição meditativa e apreciar a "arte jurídica" - para lembrar a expressão de Clóvis Bevilaqua ${ }^{25}$ - da mesma forma como escutamos o vento nas árvores, o marulhar de um riacho e o canto de um pássaro. Ela despertará dentro do coração algo que sobrepassa qualquer conhecimento ${ }^{26}$, porque saber e sentir são duas formas bem diferentes de apreensão das coisas da vida. Longe de nós desmerecer o estudo, a ilustração e o cauteloso acompanhar da evolução jurídica, mas é fato que "ninguém jamais se embebedou apenas com o conhecimento intelectual da palavra vinho"27.

Como a paixão pelas teorias, divorciada da experiência, acaba por distanciar-se do solo firme dos fatos da vida como ela é, escolhemos a análise de casos concretos para ser a base sobre a qual a tese será demonstrada. Mediante a observação, tentaremos desvendar o processo de elaboração do discurso decisório, suas principais e as suas consequências na eficácia e concretização dos direitos humanos.

Antes de passar à análise dos casos jurisprudenciais, nossa reflexão retoma, inicialmente, a história dos direitos humanos, seu fundamento e inserção no ordenamento jurídico brasileiro, para compreender melhor as etapas de sua evolução. Analisaremos, a partir de então, a distância existente entre o ordenamento jurídico e a realidade fática brasileira, no que diz respeito à aplicação e preservação dos direitos humanos de segunda geração.

Somente então, com o devido preparo teórico, demonstraremos como as normas constitucionais de proteção dos direitos humanos, que são bastante claras no ordenamento jurídico brasileiro passam a apresentar caráter vago e confuso quando têm de ser aplicadas concretamente.

\footnotetext{
${ }^{24}$ HESSEN, Johannes. Filosofia dos valores. Tradução do Professor L. Cabral de Moncada (Universidade de Coimbra). 2. ed. corr. Coimbra: Coimbra Ed., 1953. p. 55-56.

${ }^{25}$ BEVILAQUA, Clovis. Criminologia e direito. Bahia: Fonseca Magalhães, 1896. p. 134-125 e 130.

${ }^{26}$ MELLO, Anthony. O canto do pássaro. Tradução de Hebert Salvador de Lima. São Paulo: Edições Loyola, 1982. p. 14.

27 “Perguntaram, um dia, a Uwais, o Sufi:' Que inspiração lhe trouxe a Graça?' E eis o que respondeu: 'Cada manhã, ao despertar, me sinto como alguém que não tem certeza alguma de chegar vivo à tarde'. Perguntaram-lhe, ainda:' Mas, afinal, não sabem disso todos?'. E ele, de novo:'Saber sabem-no todos, certamente, mas são poucos os que o sentem! Ninguém jamais se embebedou apenas do conhecimento intelectual da palavra VINHO.'” (Id. Ibid., p. 13).
} 


\section{2. "A HISTÓRIA DE UM COMBATE" (EVOLUÇÃO DOS DIREITOS HUMANOS)}

\subsection{Natureza histórica e conflituosa dos direitos humanos}

Nascidos no mundo das ideias, marcados de intensa carga filosófica, valorativa e ideológica, os direitos humanos fizeram-se estandarte de inúmeros conflitos políticos até se consagrarem finalmente no direito positivo ${ }^{28}$. Não constituem, pois, um dado da natureza, mas um construído histórico, uma invenção humana na convivência coletiva $^{29}$. Não são "eternos nem estanques, mas trabalhados por uma série de contradições e tensões, afetados por uma dinâmica que os impele a evoluir sem cessar. Os direitos humanos têm uma história - uma história que não terminou e que continua ainda hoje a se escrever" ${ }^{30}$ Sua história é a história de um combate. ${ }^{31}$

Fosse possível viajar no tempo, com algumas paradas, perceberíamos claramente os direitos humanos como um sistema de valores que foi se desenvolvendo, aprofundando-se e alterando-se no curso da história. Valores e ideais foram incorporados pela humanidade ao longo da história, aos poucos construídos, normatizados e afirmados com maior ou menor ênfase a depender do momento histórico no qual se encontravam inseridos. Houve, até mesmo, fases de total eclipse, como aconteceu durante o horror do Holocausto $^{32}$. Em resposta a essa tragédia, a Declaração Universal dos Direitos Humanos de 1948 - marco do consenso mundial acerca do tema - esses direitos foram se expandindo e, de acordo com a realidade de cada país, acabaram agregados às respectivas ordens jurídicas internas.

Os direitos humanos podem ser compreendidos como o consenso universal acerca de um sistema de valores inerentes à própria condição humana, que se expandiu e

\footnotetext{
${ }^{28}$ LOCHAK, Danièle. op. cit., p. 4.

${ }^{29}$ LAFER, Celso. A reconstrução dos direitos humanos: um diálogo com o pensamento de Hannah Arendt, cit., p. 134.

${ }^{30}$ LOCHAK, Danièle. op. cit., p. 6. Tradução livre. O texto original diz: "les droits de l'homme ne sont ni éternels ni immuables. Ils sont travaillés par une série de contradictions, de tensions, affectés par une dynamique qui les amène à évoluer sans cesse. Les droits de l'homme ont une histoire - une histoire qui n'est pas achevée et qui continue à s'écrire encore aujoud'hui."

${ }^{31}$ Id. Ibid., p. 116.

${ }^{32}$ ARENDT, Hannah. As origens do totalitarismo. Tradução de Roberto Raposo. São Paulo: Companhia das Letras, 2007. p. 488-189.
} 
foi aprofundado no curso da História. Ao longo dela, a humanidade desenvolveu o sentido ético de que todos nós, membros da família humana, somos iguais - apesar de nossas diferenças naturais ou sociais - e, assim, portadores de direitos inalienáveis, como a nossa intrínseca dignidade ${ }^{33}$.

A busca pelo fundamento absoluto dos direitos do homem, que outrora apontava para uma certa razão universal, hoje não mais encontra resposta alguma. Os direitos humanos consistem em uma categoria mal definível e variável no tempo e espaço, moldada conforme as concepções filosóficas, morais ou religiosas variáveis no tempo e no espaço $^{34}$. O que é hoje considerado fundamental não o era no século retrasado, e talvez não mais seja no próximo. Se, no século XVIII a propriedade era "natural e imprescritível", “sagrada e inviolável" (Declaração dos Direitos do Homem e do Cidadão da Revolução Francesa de 1789 , Art. $2^{\circ}$ e $17^{\circ}$ ), no século XX, prevaleceu a ideia de que "a propriedade atenderá sua função social" (Constituição da República Federativa do Brasil de 1988, Art. $5^{\circ}$, inciso XXIII), severa limitação a um direito outrora considerado absoluto.

As contradições que envolvem os direitos do homem se apresentam já na sua própria definição. Não há conceito unânime, senão aqueles que os definem de maneira tautológica, obscura ou vazia ${ }^{35}$. O aparente consenso atingido nessas fórmulas, no entanto, desfaz-se tão logo haja necessidade de passar o enunciado para a aplicação ${ }^{36}$.

\footnotetext{
${ }^{33}$ BOBBIO, Norberto. op. cit.

${ }^{34}$ Bobbio, de forma magistral, demonstra que o relativismo deriva da pluralidade de concepções religiosas e morais, todas elas mutáveis no curso da história, sendo precisamente o relativismo o mais forte argumento em favor de alguns direitos do homem, como a liberdade de religião e liberdade de pensamento. (BOBBIO, Norberto. op. cit., p. 38-39).

${ }^{35}$ Os direitos humanos são os direitos "homem enquanto homem", ou os direitos derivados da "dignidade humana” - eis algumas dessas formulações tautológicas cujo caráter de aparente neutralidade faz conciliar os interesses divergentes.

36، [...] direitos do homem é uma expressão muito vaga. Já tentamos alguma vez defini-los? E, se tentamos, qual foi o resultado? A maioria das definições são tautológicas: 'Direitos do homem são os que cabem ao homem enquanto homem'. Ou nos dizem algo apenas sobre o estatuto desejado ou proposto para esses direitos: 'Direitos do homem são aqueles que pertencem, ou deveriam pertencer, a todos os homens, ou dos quais nenhum homem deveria ser despojado'. Finalmente, quando se acrescenta alguma referência ao conteúdo, não se pode deixar de introduzir termos avaliativos: 'Direitos do homem são aqueles cujo reconhecimento é condição necessária para o aperfeiçoamento da pessoa humana, ou para o desenvolvimento da civilização, etc., etc.' . E aqui nasce uma nova dificuldade: os termos avaliativos são interpretados de modo diverso conforme a ideologia assumida pelo intérprete; com efeito, é objeto de muitas polêmicas apaixonantes, mas insolúveis, saber o que se entende por aperfeiçoamento da pessoa humana ou por desenvolvimento da civilização. O acordo é obtido, em geral, quando os polemistas depois de muitas concessões recíprocas - consentem em aceitar uma fórmula genérica, que oculta e não resolve a contradição: essa fórmula genérica conserva a definição no mesmo nível de generalidade em que aparece nas duas definições precedentes. Mas as contradições que são assim afastadas renascem quando se passa do momento de enunciação puramente verbal para o da aplicação” (BOBBIO, Norberto. op. cit., p. 37).
} 
Tal natureza conflitiva dos direitos humanos - especialmente dos direitos sociais - com frequência os leva à apreciação do Judiciário. A aplicação dos direitos humanos torna-se, assim, tarefa muito grave - por implicar uma escolha concreta e consciente entre os valores antinômicos latentes no texto da norma, opção que não se faz imune a orientações políticas, ideológicas e axiológicas. O magistrado, diante de um caso de aplicação dos direitos humanos, vê-se árbitro desse conflito de valores e interesses, tendo de buscar "a concordância prática das diversidades"37.

Para bem captar o modo de pensar do magistrado diante desse embate, fazse necessário esboçar um panorama da lenta e gradual afirmação dos direitos do homem e, em seguida, analisar com maior profundidade as conflitos inerentes aos direitos "de segunda geração" ${ }^{38}$. Somente a partir dessa compreensão, podem-se propor soluções práticas que assegurem atuação do juiz em prol da garantia dos direitos sociais.

\subsection{Fundamentos dos direitos humanos}

Se formos buscar as raízes da formulação da dignidade humana e, por conseguinte, dos direitos do homem, regressaremos às bases religiosas e filosóficas de nossa civilização ocidental: o legado do estoicismo, do judaísmo, do cristianismo e das formulações modernas do direito natural. Todas essas concepções trazem em comum o desenvolvimento da ideia de que a pessoa não se perde no todo do corpus social, mas é, individualmente, dotada de direitos - direitos subjetivos ${ }^{39}$. Rompe-se, assim, a tradição holística da Antiguidade em prol da visão individualista ${ }^{40}$ típica da modernidade.

\footnotetext{
37،El imperativo teórico de no contradicción - valido para la scientia juris - no deberá obstaculizar la labor, propria de la jurisprudencia, de intentar realizar positivamente la concordancia práctica de las diversidades [...]'ZAGREBELSKY, Gustavo. El derecho dúctil: ley, derechos, justicia. Trad. de Marina Gascón. 7. ed. Madrid: Trotta, 2007. p. 16.

${ }^{38}$ Esses direitos representam um direito de crédito do cidadão perante o Estado, conforme Celso LAFER, Celso. A reconstrução dos direitos humanos: um diálogo com o pensamento de Hannah Arendt, cit., p. 127). Contudo, no atual contexto brasileiro, o constituinte garantiu muito mais direitos do que a coletividade está realmente disposta a conceder. Essa contradição, inerente ao capitalismo e ao Estado Social, será mais bem explorada a seguir.

${ }^{39}$ LAFER, Celso. A internacionalização dos direitos humanos: o desafio do direito a ter direitos. Revista do Tribunal Regional Federal da $3^{a}$ Região, n. 75, p. 37, jan./fev. 2006.

${ }^{40}$ Não se faz aqui qualquer julgamento valorativo sobre o "individualismo", apenas se constata a prevalência da pessoa sobre o organismo social, em oposição ao "holismo" dos antigos, que dissolvia a individualidade na comunidade.
} 
O holismo da Antiguidade consubstanciava-se na ideia de que o homem era parte da natureza e pertencia à ordem do cosmos. A política e o direito serviam a essa ordem universal, de forma a garantir a harmonia e a reprodução dos modelos tradicionais, mantendo-se as desigualdades tidas por naturais ${ }^{41}$.

Ainda assim, houve espaço, especialmente entre os socráticos, para algumas concepções mais voltadas para o indivíduo, as quais atingiram seu ápice na escola estoica. $\mathrm{O}$ advento do estoicismo, paralelo à emergência dos grandes impérios, faz com que se deixe de identificar o homem como cidadão local da polis para concebê-lo como cidadão universal da cosmopolis.

O monoteísmo judeu rompeu com a percepção holística do mundo, ao alçar a criatura humana a um status superior ao restante da criação divina. Imagem e semelhança de Deus, o homem se reveste de uma nova e absoluta dignidade. ${ }^{42} \mathrm{O}$ cristianismo aperfeiçoou essa ideia ao lhe acrescer o elemento universal helênico ${ }^{43}$ e, assim, radicalizar o conceito de igualdade, expressa por São Paulo na epístola aos Gálatas: “Já não há nem judeu nem grego, nem escravo nem livre, nem homem nem mulher" ${ }^{\prime 4}$. No entanto, a igualdade cristã ficou, por muitos séculos, restrita ao plano espiritual - sem intenção de se imiscuir nos negócios temporais, ou seja, de exigir das autoridades políticas a positivação das normas que garantissem a dignidade.

Com a "descoberta" do Novo Mundo e o contato dos europeus com os ameríndios, surge intenso debate entre os teólogos espanhóis. De um lado, Juan Ginés de Sepúlveda (1490-1573) sustentava que os índios americanos eram "inferiores aos espanhóis assim como as crianças em relação aos adultos, as mulheres em relação aos homens e até mesmo, pode-se dizer, os macacos em relação aos seres humanos"45, no entanto, Francisco de Vitória (1483-1512) e Bartolomé de Las Casas (1474-1566) viam no indígena a inata dignidade da pessoa humana. Passava-se, portanto, de uma concepção de universalidade fundada na fé comum para um universalismo derivado da natureza comum da humanidade.

\footnotetext{
${ }^{41}$ LOCHAK, Danièle. op. cit., p. 8-9.

${ }^{42}$ Id. Ibid., p. 9.

${ }^{43}$ COMPARATO, Fabio Konder. A afirmação histórica dos direitos humanos. 3. ed. São Paulo: Brasiliense, 1989. p. 17-18.

${ }^{44} \mathrm{Gl} \mathrm{3,} 28$.

${ }^{45}$ Id. Ibid., p. 18.
} 
O holandês Hugo Grócio (1583-1645) e o alemão Samuel von Pudendorf (1632-1694) trataram de laicizar as concepções do direito natural, atribuindo-lhe não mais a religião, mas a razão humana como fundamento. Desenvolveu-se, assim, a noção do contrato social: os homens, em sua liberdade e em virtude de sua razão, acordam voluntariamente em organizar a sociedade da maneira mais racional ${ }^{46}$. Pela primeira vez, assume-se que a legitimidade do poder não vem de "cima para baixo", da própria autoridade divina ou do príncipe, mas de "baixo para cima", surgindo do consenso dos governados.

Os ingleses Thomas Hobbes (1588-1679) e John Locke (1632-1704), apoiando-se no conceito do contrato social, exploram as relações do indíviduo com o poder, ao enfatizarem a necessidade de limitação deste para a proteção daquele ${ }^{47}$. JeanJacques Rousseau (1712-1718), finalmente, vai aperfeiçoar essas ideias e identificar a própria liberdade com a obediência das leis ${ }^{48}$. Esse pensamento contratualista será amalgamado por outros filósofos iluministas, como Montesquieu - que insistirá no universalismo -, Immanuel Kant - que faz a separação ética entre pessoas e coisas ${ }^{49}-\mathrm{e}$ Voltaire - que conclama a passagem da teoria para a ação em defesa da liberdade, abrindo caminho para as revoluções liberais ${ }^{50}$ e a positivação dos direitos humanos, primeira etapa no gradual processo de sua afirmação.

\footnotetext{
${ }^{46}$ LOCHAK, Danièle. op. cit., p. 13.

${ }^{47}$ “O contratualismo inspirou a tutela dos direitos humanos pela constituição, pois um dos ingredientes da passagem do Estado absolutista para o Estado de direito foi a preocupação em estabelecer limites ao poder discricionário do soberano em relação às pessoas que integram a sociedade. Daí a ideia-força de combinar a divisão de poderes - na lição clássica de Montesquieu - com uma decaração de direitos, ambas expressas num texto escrito: a constiuição. É este o sentido do art. 16 da Declaração Francesa dos Direitos do Homem e do Cidadão, de 1789: "Toda sociedade na qual a garantia dos direitos não é assegurada nem a separação dos poderes determinada não tem constituição." (LAFER, Celso. Parecer. Caso Ellwanger: anti-semitismo como crime da prática do racismo. In: . A internacionalização dos direitos humanos: constituição, racismo e relações internacionais. Barueru, SP: Manole, 2005. p. 35).

${ }^{48}$ LOCHAK, Danièle. op. cit., p. 15-16.

49،"Daí decorre, como assinalou o filósofo [Kant] que todo homem tem dignidade, e não um preço, como as coisas. A humanidade, como espécie, e cada ser humano em sua individualidade, é propriamente insubstituível: não tem equivalente, não pode ser trocado por coisa alguma. Pela sua vontade racional, a pessoa, ao mesmo tempo que se submete às leis da razão prática, é a fonte dessas mesmas leis, de âmbito universal, segundo o imperativo categórico - 'age unicamente segundo a máxima, pela qual tu possas querer, ao mesmo tempo, que ela se transforme em lei geral"' (COMPARATO, Fabio Konder, op. cit., p. 21).

${ }^{50}$ LOCHAK, Danièle. op. cit., p. 13-16.
} 


\subsection{Uma afirmação por etapas}

\subsubsection{Secularização e sistematização}

Os direitos humanos são fruto de um combate, um combate centrado, no primeiro momento, nas limitações da discricionariedade do poder estatal. "A eclosão da consciência histórica dos direitos humanos só se deu após um longo trabalho preparatório centrado em torno da limitação do poder político". ${ }^{51}$ Uma necessidade de garantia mínima da dignidade individual é o que motivou as revoluções liberais, que ensejaram, em nossa civilização ocidental moderna, os primeiros documentos escritos reconhecendo os direitos do homem.

O primeiro movimento desse processo ${ }^{52}$, a partir do aparecimento do Estado moderno, foi a secularização do direito natural, promovida por Hugo Grócio. A partir dela, os contratualistas trataram de desenvolver uma visão racional e sistemática do direito natural. Essa sistematização, segundo passo da afirmação, "constituiu um aspecto fundamental da contribuição do Direito Natural à jurisprudência europeia, que deixou de limitar-se à exegese e à interpretação prudencial de textos singulares e passou a ter características de uma estrutura lógico-demonstrativa" ${ }^{, 53}$.

A sistematização acabou fazendo dos códigos e das constituições promulgados pelas revoluções liberais uma "ponte involuntária entre o jusnaturalismo e o positivismo jurídico" ${ }^{, 54}$. A terceira etapa, a positivação, veio como artifício das revoluções para garantir seus ideais, impondo-lhes, ainda, valor hierárquico ao deles fazer normas constitucionais ${ }^{55}$.

\footnotetext{
${ }^{51}$ COMPARATO, Fabio Konder, op. cit., p. 40.

${ }^{52}$ LAFER, Celso. A reconstrução dos direitos humanos: um diálogo com o pensamento de Hannah Arendt, cit., p. 38.

${ }^{53}$ Id. Ibid., p. 39.

${ }^{54}$ Id. Ibid., p. 38-39.

${ }^{55}$ Id. A internacionalização dos direitos humanos: o desafio do direito a ter direitos, cit., p. 38.
} 


\subsubsection{Positivação}

De fato, desde há muito, a positivação do direito é vista como uma forma de garantia contra a tirania. Já os antigos atenienses viam na lei escrita o "grande antídoto contra o arbítrio governamental", tal qual se depreende dos versos de Eurípedes: "uma vez escritas as leis, o fraco e o rico gozam de um direito igual; o fraco pode responder ao insulto do forte, e o pequeno, caso esteja com a razão, vencer o grande",56

Os primeiros direitos humanos a serem positivados - a chamada "primeira geração" - foram os direitos civis e políticos, fundados nos valores do contexto liberal e iluminista, entendendo "que o governo é para o indivíduo e não o indivíduo é para o governo e que a liberdade requer a distribuição de poder econômico, cultural e político entre os governados e exige limitações impostas pelo Direito à discricionariedade do poder dos governantes" 57

No compasso de sua positivação, houve importantes marcos como a Magna Carta (1215), a Declaração de Direitos inglesa (Bill of Rights de 1689), a Declaração de Independência dos Estados Unidos da América (1776) e a Declaração de Direitos do Homem e do Cidadão da Revolução Francesa (1789).

A segunda onda de positivação veio mais de um século depois, com o legado do socialismo e das lutas por justiça social que se seguiram à consolidação do capitalismo industrial, exigindo a "igualdade concreta como resposta à crítica ao formalismo jurídico por meio do reconhecimento do valor da pessoa humana tanto como 'pessoa moral' como 'pessoa social"" ${ }^{\circ 8}$. Afinal, se, por um lado, a moderna concepção individualista retirava a proteção do clã, da família e do estamento, oferecia em troca a segurança da legalidade, com a promessa de igualdade de todos perante a lei. No entanto, "essa isonomia cedo se revelou como uma pomposa inutilidade para a legião crescente de trabalhadores, compelidos a se empregarem nas empresas capitalistas",59.

O sujeito dos direitos de segunda geração, portanto, não é mais o "ser humano abstrato, com o qual o capitalismo sempre conviveu maravilhosamente. É o

\footnotetext{
${ }^{56}$ COMPARATO, Fabio Konder, op. cit., p. 12-13.

${ }^{57}$ LAFER, Celso. A internacionalização dos direitos humanos: o desafio do direito a ter direitos, cit., p. 39.

${ }^{58}$ Id. Ibid.

${ }^{59}$ COMPARATO, Fabio Konder, op. cit., p. 52.
} 
conjunto de grupos sociais esmagados pelo miséria, a doença, a fome, a marginalização"60. Os marcos inaugurais da positivação desses direitos foram a Constituição Mexicana de 1917 e a Constituição Alemã de 1919 (Constituição de Weimar).

Estamos cientes de que, na segunda metade do século passado, também floresceu a dita "terceira geração" dos direitos humanos, que corresponderia àqueles de titularidade difusa, como o direito ao meio ambiente preservado.

\subsubsection{Internacionalização}

Todas as construções e afirmações até então estabelecidas foram eclipsadas por completo na era de Hitler; época marcada pelo império da destruição e da descartabilidade da pessoa humana ${ }^{61}$, levando ao extermínio de milhões de pessoas ciganos, negros, homossexuais e, sobretudo, judeus.

No cenário do pós-guerra, a humanidade, desorientada e assombrada com a sua própria capacidade de destruição, esforçou-se na reconstrução dos direitos humanos. Esse assombro universal que marcava o pós-guerra ficou bem expresso na célebre formulação da Carta da Organização das Nações Unidas:

NÓS, OS POVOS DAS NAÇÕES UNIDAS, RESOLVIDOS a preservar as gerações vindouras do flagelo da guerra,que por duas vezes, no espaço da nossa vida, trouxe sofrimentos indizíveis à humanidade, e a reafirmar a fé nos direitos fundamentais do homem, na dignidade e no valor do ser humano, na igualdade de direito dos homens e das mulheres, assim como das nações grandes e pequenas, e a estabelecer condições sob as quais a justiça e o respeito às obrigações decorrentes de tratados e de outras fontes do direito internacional possam ser mantidos, e a promover o progresso social e melhores condições de vida dentro de uma liberdade ampla; E PARA TAIS FINS, praticar a tolerância e viver em paz, uns com os outros, como bons vizinhos, e unir as nossas forças para manter a paz e a segurança internacionais, e a garantir, pela aceitação de princípios e a instituição dos métodos, que a força armada não será usada a não ser no interesse comum, a empregar um mecanismo internacional para promover o progresso econômico e social de todos os povos; RESOLVEMOS CONJUGAR NOSSOS ESFORÇOS PARA A CONSECUÇÃO DESSES OBJETIVOS. $^{62}$

\footnotetext{
${ }^{60}$ COMPARATO, Fabio Konder, op. cit., p. 53.

${ }^{61}$ PIOVESAN, Flávia. Direitos humanos e justiça internacional. São Paulo: Saraiva, 2006. p. 92.

${ }^{62}$ Preâmbulo da Carta das Nações Unidas.
} 
Era o início da etapa da internacionalização dos direitos humanos ${ }^{63}$. Sob a ideia de que a condição de pessoa é requisito bastante para a dignidade e a titularidade de direitos, a Declaração Universal dos Direitos Humanos tornou-se marco do processo de sua reconstrução, servindo de referencial ético e orientador da ordem internacional contemporânea $^{64}$. Aprovada pela Assembléia Geral das Nações Unidas por quarenta e oito votos a favor, oito abstenções e nenhuma oposição, consagrou o consenso universal acerca da proteção de direitos civis e políticos - chamados "de primeira geração" (artigos 3 a 21) - bem como dos direitos sociais, econômicos e culturais - chamados "de segunda geração" (artigos 22 a 28).

Essa Declaração, posteriormente reiterada pela Declaração e Programa de Ação da II Conferência Mundial de Direitos Humanos, realizada sob os auspícios da Organização das Nações Unidas (ONU) na cidade de Viena em 1993, implicou o reconhecimento da interdependência ${ }^{65}$ entre as gerações de direitos humanos e da existência de uma interpenetração funcional entre eles ${ }^{66}$.

${ }^{63} \mathrm{Cf}$. BOBBIO, Norberto. op. cit.

64"A Declaração Universal dos Direitos Humanos foi adotada em 10 de dezembro de 1948, pela aprovação unânime de 48 Estados, com 8 abstenções. A inexistência de qualquer questionamento ou reserva feita pelos Estados aos princípios da Declaração e a inexistência de qualquer voto contrário às suas disposições conferem à Declaração Universal o significado de um Código e plataforma comum de ação. A Declaração consolida a afirmação de uma ética universal, ao consagrar um consenso sobre valores de cunho universal a serem seguidos pelos Estados" (PIOVESAN, Flávia. op. cit., p. 33).

65،Daí a complementaridade, na perspectiva 'ex parte populi', entre os direitos de primeira e de segunda geração, pois estes últimos buscam assegurar as condições para o pleno exercício dos primeiros, eliminando ou atenuando os impedimentos ao pleno uso das capacidades humanas. Por isso, os direitos de crédito, denominados direitos econômico-sociais e culturais, podem ser encarados como direitos que tornam reais direitos formais: procuraram garantir a todos o acesso aos meios de vida e de trabalho num sentido amplo" (LAFER, Celso. A reconstrução dos direitos humanos: um diálogo com o pensamento de Hannah Arendt, cit., p. 127).

${ }^{66 " S e}$ passarmos agora a examinar mais acuradamente essas classes ou gerações de direitos humanos, não demonstraremos a perceber como as fronteiras entre umas e outras se esbatem e tendem a dar lugar a uma interpretação funcional entre todos eles. Tem sido largamente aceita, por exemplo, a idéia de que a primeira geração é composta de direitos individuais, cuja pretensão se exerce contra o Estado. É esse um dogma acreditado na pregação liberal, que sustenta ser o indivíduo tanto mais livre quanto mais direitos tenha contra a interferência estatal em sua vida privada. Mas de que forma é exercida essa pretensão, no esquema constitucional clássico? Obviamente, pelos consagrados remédios judiciários do tipo mandamental, os writs de habeas corpus e de mandado de segurança. . Então, não é que o indivíduo manifesta suas liberdades fundamentais, pois a proteção destas é buscada junto a um órgão estatal, o Judiciário. Seria preciso afinar a fórmula tradicional e dizer que as liberdades individuais são protegidas pela autoridade do Estado-árbitro contra os abusos do Estado-poder". [...] "Pretender, portanto, que a defesa da liberdade individual possa realizar-se sem o esforço e a adequada organização do Poder Público constitui um grave erro público; e os erros políticos, como já se advertiu, costumam produzir consequências mais funestas que os crimes políticos. Se a interpretação da primeira geração dos direitos humanos como dirigida contra o Estado merece retificação, há de ser também corrigida a idéia de que tais direitos são individuais, senão personalíssimos. Inegavelmente, cada pessoa, desde a realidade biológica da composição do código genético, é uma individualidade única. Mas no plano da vida social, os interesses sociais a serem protegidos costumam se reproduzir nos componentes da mesma raça, da mesma classe ou do mesmo estrato social." (COMPARATO, Fabio Konder. Para viver a democracia. São Paulo: Brasiliense, 1989. p. 47-49). 
A subscrição da Declaração de Viena por cento e setenta e um Estados demonstrou a existência de consenso acerca da extensão universal dos direitos humanos, bem como de sua interdependência e indivisibilidade. Seu artigo $5^{\circ}$ reconhece que "os direitos humanos são universais, indivisíveis, interdependentes e inter-relacionados. A comunidade internacional deve tratar os direitos humanos globalmente de forma justa e eqüitativa, em pé de igualdade e com a mesma ênfase".

Desde 1948, além dessas declarações globais, vêm se desenhando instrumentos regionais de proteção dos direitos humanos, cada qual com um aparato jurídico próprio. Consolidou-se, assim, a coexistência de um sistema global de proteção (integrado pelos instrumentos das Nações Unidas) com instrumentos dos sistemas regionais, como o sistema americano, cujo principal instrumento é a Convenção Americana sobre Direitos Humanos de 1969, que estabelece a Comissão Interamericana de Direitos Humanos e a Corte Interamericana; o sistema europeu com a Convenção Europeia de Direitos Humanos de 1950, a qual estabelece a Corte Europeia de Direitos Humanos e, por fim, o sistema africano com a Carta Africana de 1981, que, por sua vez, estabelece a Comissão Africana de Direitos Humanos.

A Convenção Americana sobre Direitos Humanos foi assinada em San José, Costa Rica, em 1969, entrando em vigor em 1978. É a base do sistema interamericano, no qual o Brasil se insere. Dentro do universo dos direitos por ela assegurados, destacam-se os direitos à personalidade jurídica, à vida, a não ser submetido à escravidão, à liberdade, a um julgamento justo, a compensação em caso de erro judiciário, à privacidade, à liberdade de consciência e religião, à liberdade de pensamento e expressão, à resposta, à liberdade de associação, ao nome, à nacionalidade, à liberdade de movimento e residência, a participar do governo, à igualdade perante a lei e à proteção judicial. Não se enuncia, de forma específica, qualquer direito social, cultural ou econômico, os quais acabaram sendo objeto de um Protocolo Adicional à Convenção, em 1988 (Protocolo de San Salvador).

O Brasil foi um dos Estados Membros que mais tardiamente aderiu à Convenção, fazendo-o apenas em 25 de setembro de 1992, já na vigência da nova ordem constitucional democrática instaurada em 1988. 


\subsubsection{Generalização e especificação}

O século passado também assistiu a dois movimentos a princípio contraditórios, porém complementares: a generalização e a especificação dos direitos humanos ${ }^{67}$. No primeiro momento, buscava-se albergar todos os seres humanos sob a tutela dos mesmos direitos, para, em seguida, aprofundá-la do homem abstrato para os grupos que precisavam de proteção específica: mulheres, crianças, idosos, minorias étnicas e religiosas, entre outros.

A generalização é um movimento expansivo e diastólico, que remonta às primeiras declarações de direitos, as quais os expandiam para todos os homens, sem distinção de estamento, cidadania ou nacionalidade. Eclodindo na efervecência dos levantes liberais do final dos séculos XVIII e XIX, atingiu seu ápice no século XX com a conquista do voto feminino e a queda dos regimes de discriminação étnica institucionalizada (dos quais são exemplo o apartheid vigente até há poucas décadas na África do Sul e outras formas de segregação, como as vigentes até meados do século passado nos Estados Unidos da América, as quais motivaram a luta de Martin Luther King Jr. pelos direitos civis dos negros).

Percebe-se, claramente, que o movimento de generalização, fundado na ideia de isonomia, é paralelo à positivação daqueles direitos políticos ("primeira geração"). Quando estes já não se fazem bastantes para atender os anseios despertos pelo socialismo e começam-se a exigir os direitos sociais, econômicos e culturais ("segunda geração"), igualmente se nota o advento de um novo movimento: a especificação.

Este segundo momento tem caráter de sístole e aprofundamento: já não basta apenas tutelar o "ser humano" abstrato, mas é preciso dar de comer, de morar e de vestir ao homem e à mulher reais, explorado pela voraz expansão do capitalismo industrial. Tímido no início, o movimento de especificação atinge seu ápice nas décadas finais do século $\mathrm{XX}$, quando surgem as regras específicas de tutela dos direitos das mulheres, das crianças e adolescentes, das minorias étnicas e religiosas, dos idosos e das pessoas portadoras de deficiência.

No âmbito internacional, assistimos ao advento da Convenção sobre a Eliminação de Todas as Formas de Discriminação Racial, em 21 de dezembro de 1965, da

\footnotetext{
${ }^{67}$ BOBBIO, Norberto. op. cit., p. 79.
} 
Convenção sobre a Eliminação de Todas as Formas de Discriminação contra a Mulher, em 18 de dezembro de 1979 e da Convenção das Nações Unidas sobre os Direitos da Criança de 20 de novembro de 1989 - marcos desse fenômeno de especificação.

Paralelamente, no Brasil, embora mais lentamente, o mesmo processo se desenhava, como, por exemplo, no Estatuto da Mulher Casada (Lei 4.121 de 1962), mas seu marco fundamental foi a própria Constituição da República de 1988 - que restabeleceu a ordem democrática e tratou de assegurar, no mais alto patamar do nosso ordenamento jurídico, os direitos humanos específicos das mulheres, das crianças, dos idosos, dos deficientes e de outros grupos sensíveis, ampliando sua proteção.

O processo continuou a se aperfeiçoar após 1988, com o advento de importante legislação infraconstitucional como o Estatuto da Criança e do Adolescente (Lei 8.069 de 1990), o Estatuto da Pessoa com Deficiência (Decreto no 3.298 de 1999, que regulamenta a Lei 7.853 de 1989), o Estatuto do Idoso (Lei 10.741 de 2003), a Lei Maria da Penha (Lei 11.340 de 2006).

Visualizam-se assim, na prática, as palavras de Danièle Lochak: o combate pelos direitos humanos não cessa ${ }^{68}$, e a marcha por sua conquista sempre continua ao passo da História.

${ }^{68}$ LOCHAK, Danièle. op. cit. 


\title{
3. A “CONSTITUIÇÃO CIDADÃ" DE 1988
}

\subsection{Um amálgama de forças políticas}

A Constituição da República Federativa do Brasil, promulgada em 5 de outubro de 1988 pelos representantes do povo reunidos em Assembleia Constituinte, ficou conhecida como Constituição Cidadã. Foi o alvorecer da democracia após as trevas autoritárias do regime militar e fez consolidar todas as etapas da afirmação dos direitos humanos. Cristalização dos anseios da sociedade brasileira de seu tempo, a Constituição foi pródiga ao reconhecer um amplo espectro de direitos humanos individuais e sociais.

\begin{abstract}
"Repito: essa será a Constituição cidadã, porque recuperará como cidadãos milhões de brasileiros, vítimas da pior das discriminações: a miséria. Cidadão é o usuário de bens e serviços do desenvolvimento. Isso hoje não acontece com milhões de brasileiros, segregados nos guetos da perseguição social. Esta Constituição, o povo brasileiro me autoriza a proclamá-la, não ficará como bela estátua inacabada, mutilada ou profanada. O povo nos mandou aqui para fazê-la, não para ter medo. Viva a Constituição de 1988 ! Viva a vida que ela vai defender e semear!" 69
\end{abstract}

Espelho das confrontações políticas do momento histórico em que surgiu, a Constituição de 1988 leva esses direitos ao ápice da ordem normativa e vinculante dos poderes estatais $^{70}$. Todavia, ao pararmos para pensar, percebemos que, após quase vinte anos da promulgação da nossa Constituição, esses direitos, expressos de forma tão clara, não vêm sendo respeitados. Aqui e ali se depara com o portador de deficiência sem escola e sem acesso a lugares públicos, idosos sem amparo assistencial, presos sem garantias, doentes sem atendimento - são apenas alguns exemplos da falta de eficácia ${ }^{71}$ daqueles direitos tão evidentes no texto constitucional.

\footnotetext{
${ }^{69}$ Discurso proferido por Ulysses Guimarães, presidente da Assembléia Nacional Constituinte, na sessão de 27 de julho de 1988.

${ }^{70}$ CANOTILHO, Joaquim José Gomes. op. cit., p. 150.

${ }^{71}$ A importância crescente do Estado Social no seio do constitucionalismo forçou o recrudescimento da questão da eficácia, posto que a atribuição ao Estado de responsabilidades impôs o crescimento de normas programáticas e, em conseqüência, a reflexão sobre a chamada eficácia técnica." (FERRAZ JUNIOR, Tércio Sampaio. Interpretação e estudos da Constituição de 1988. São Paulo: Atlas, 1990. p. 15).
} 
O fundamento dos direitos humanos no Brasil é, portanto, encontrado dentro do próprio ordenamento jurídico ${ }^{72}$, já que há normas que os reconhecem positivadas na própria carta constitucional. A Constituição Cidadã instituiu um Estado Democrático, destinado a assegurar o exercício dos direitos individuais e sociais, a liberdade, a segurança, o bem-estar, o desenvolvimento, a igualdade e a justiça como valores supremos de uma sociedade fraterna, pluralista e sem preconceitos - fundada na harmonia social e comprometida, na ordem interna e internacional, com a solução pacífica das controvérsias.

A dignidade da pessoa humana foi eleita como um dos fundamentos do Estado brasileiro $^{73}$, cujos objetivos fundamentais são a construção de uma sociedade livre, justa e solidária $^{74}$, a garantia de desenvolvimento nacional ${ }^{75}$, a erradicação da pobreza e da marginalização ${ }^{76}$, a redução das desigualdades sociais e regionais, a promoção do bem de todos - sem preconceitos de origem, raça, sexo, cor, idade e quaisquer outras formas de discriminação $^{77}$. O repúdio à discriminação - reflexo do movimento de generalização dos direitos humanos - é especialmente favorecido ao ser incluído no rol dos princípios que devem guiar a ação do Brasil na esfera internacional ${ }^{78}$, e pela tipificação do racismo como crime imprescritível ${ }^{79}$.

No capítulo destinado aos direitos e deveres individuais e coletivos, foi assegurada a inviolabilidade do direito à vida, à liberdade, à igualdade, à segurança e à propriedade $^{80}$ além dos direitos à saúde, ao trabalho, à moradia, ao lazer, à educação e à cultura, bem como a previdência social, a proteção à maternidade e a assistência aos desamparados ${ }^{81}$.

\footnotetext{
${ }^{72 "} \mathrm{O}$ problema do fundamento de um direito apresenta-se diferentemente conforme se trate de buscar o fundamento de um direito que se tem ou de um direito que se gostaria de ter. No primeiro caso, investigo no ordenamento jurídico positivo, do qual faço parte como titular de direitos e de deveres, se há uma norma válida que o reconheça e qual é essa norma; no segundo caso, tentarei buscar boas razões para defender a legitimidade do direito em questão e para convencer o maior número possível de pessoas (sobretudo as que detêm o poder direto ou indireto de produzir normas válidas naquele ordenamento) a reconhecê-la". BOBBIO, Norberto. op. cit., p. 35.

${ }^{73} \mathrm{CF}$, Art. $1^{\circ}$, III.

${ }^{74} \mathrm{CF}$, Art. $3^{\circ}, \mathrm{I}$.

${ }^{75} \mathrm{CF}$, Art. $3^{\circ}$, II.

${ }^{76} \mathrm{CF}$, Art. $3^{\circ}$, III.

${ }^{77} \mathrm{CF}$, Art. $3^{\circ}$, IV.

${ }^{78} \mathrm{CF}$, Art. $4^{\circ}$, VII.

${ }^{79} \mathrm{CF}$, Art. $5^{\circ}$, XLII.

${ }^{80} \mathrm{CF}$, Art. $5^{\circ}$, caput.

${ }^{81} \mathrm{CF}$, Art. $6^{\circ}$, caput.
} 
Indo mais além, também garantiu o direito à assistência social ${ }^{82}$, a ser prestada a quem dela necessitar, independentemente de contribuição, tendo por objetivos, dentre outros, a habilitação e reabilitação das pessoas portadoras de deficiência e a promoção de sua integração à vida comunitária, bem como a garantia de um salário mínimo de beneficio mensal à pessoa portadora de deficiência e ao idoso que comprovem não possuir meios de prover a própria manutenção ou tê-la provida por sua família.

Entretanto, não obstante o aparato jurídico existente para salvaguarda desses direitos, verificamos que os valores neles consagrados existem apenas no plano teórico. Embora escritas com clareza, o caráter vago, confuso e impreciso dessas normas aparece tão logo tenham de ser aplicadas no caso concreto ${ }^{83}$.

A sociedade brasileira, cujos anseios foram cristalizados em 1988, aguardou, em vão, que o poder Legislativo complementasse as normas constitucionais, dando a elas a eficácia necessária para se tornarem exigíveis. O Executivo, na mesma linha, manteve-se impassível - insistindo na ideia de que a Constituição, dado o seu caráter "programático",84, não delineia obrigações, apenas traçando algumas esperanças e apresenta meros vetores de orientação. Verifica-se, assim, que a ordem jurídica suprema ficou no plano das ideias, seguindo um caminho paralelo ao mundo dos fatos, sem ponto de encontro.

Nesse contexto, surge a pergunta: será que os "direitos humanos" são mesmo "direitos" ou servem apenas de bálsamo para uma sociedade carente de valores ${ }^{85}$ ? Será que as regras contidas no texto constitucional são meros conselhos a serem ou não seguidos de acordo com o arbítrio e a conveniência?

A resposta não é simples e nem pode ser dada de pronto, mas é certo que, enquanto se discute a natureza dessas normas ou desses princípios, o Estado não se obriga e o cidadão nada recebe. A Constituição, então, fica relegada ao descrédito, e o Estado de Direito passa a ser meramente formal.

Ante a inércia e o fala de confiança da sociedade nas classes políticas ${ }^{86}$ que formam o Legislativo e do Executivo, a aplicação dos direitos humanos passa a depender

\footnotetext{
${ }^{82} \mathrm{CF}$, Art. 203, caput.

${ }^{83} \mathrm{~V}$. nota 35.

${ }^{84} \mathrm{~V}$. nota 13.

${ }^{85}$ Cf. NEVES, Marcelo. A constitucionalização simbólica. São Paulo: Acadêmica, 1994.

${ }^{86}$ CAMPILONGO, Celso Fernandes. Os desafios do Judiciário: um enquadramento teórico. In: FARIA, José Eduardo (Org.). Direitos humanos, direitos sociais e justiça. São Paulo: Malheiros Ed., 2005. p. 32.
} 
do papel desempenhado pelo Judiciário ${ }^{87}$. Este, a quem incumbe aplicar a lei nos casos contenciosos, garantindo os direitos humanos vindicados, apresenta-se, por sua vez, tímido, medroso, cheio de dificuldades para reconhecer as pretensões apresentadas. Porém, é necessário que os juízes rompam definitivamente com esse acanhado comportamento, para que possam assumir o papel que lhes cabe, qual seja, a "concordância prática das diversidades" $" 88$ inerentes ao Estado social.

"Para os segundos [direitos humanos de segunda geração], por seu turno, o problema está em harmonizar os diferentes tipos de direitos legalmente garantidos para suprir vazios de efetividade e alargar sua intensidade a amplos setores das classes trabalhadoras. Os desafios redistributivos impostos ao sistema político e cobrados ao sistema Judicial são muito mais fortes.

Os grupos sociais têm percebido o Judiciário como um locus de afirmação desses direitos e superação desse déficit. Trata-se, evidentemente, de uma sinalização do cidadão no sentido da legitimação da magistratura ${ }^{89}$

\subsection{Dilemas do Estado Social}

A ordem constitucional brasileira, ao virtualizar um Estado de bem-estar social, engendrou as normas que agasalham os direitos humanos sociais por meio de barganhas e negociações, formando uma legislação ao estilo "colcha de retalhos", capaz de atender interesses antagônicos: sistema capitalista e Estado Social, que precisam coexistir.

O sistema econômico do capitalismo contemporâneo não pode existir sem o

Estado bem-estar social, mas também não pode tolerar a sua expansão contínua ${ }^{90}$. $\mathrm{O}$ governo, nessa perspectiva, tem de se esforçar para obter simultaneamente o apoio das

\footnotetext{
87،Num tempo de grande descrédito da política (e sobretudo dos políticos), as esperanças tendem a depositarse noutros protagonistas do poder, ou da soberania. Não havendo reis que oiçam os clamores do povo, quem fica investido hodiernamente nessa função, que aliás lhe fica bem, é o pode judicial.

Se nas vésperas da Revolução Francesa era quase proverbial a ideia de que os tribunais eram arbitários (dizia-se algo como 'Deus nos livre dos Parlements'), parece que esse tempo foi dando lugar a outro. Os juízes parecem ser a última esperança de uma sociedade que perdeu os seus freios e contrapesos naturais: que não acredita mais na autoridade e na sabedoria familiares, nem dos mais velhos, nem dos notáveis ou mesmo dos homens bons, nem crê na composição amigável dos conflitos por mediação ou discussão, que quer decisões liminares, e com força jurídica que já não há religião as mais das vezes e quando a diz ainda ter, a adapta muito criativamente aos interesses pessoais, que já não tem moral, ou, se afirma possuí-la, faz o mesmo, e que não tem modos, maneiras nem trato. Numa sociedade assim apenas o juiz é garante de alguma pacificação social - mas com que custos!" CUNHA, Paulo Ferreira da. Anti-Leviatã: direito, política e sagrado. Porto Alegre: Sergio Fabris, 2005. p. 22-23.

${ }^{88}$ ZAGREBELSKY, Gustavo. op. cit., p. 16, v. nota 36.

${ }^{89}$ CAMPILONGO, Celso Fernandes. op. cit., p. 31-32.

${ }^{90} \mathrm{Cf}$. HABERMAS, Jürgen. op. cit.
} 
massas e dos investidores privados. Nesse contexto, a administração não só estrutura o processo de legislação como também o controla. Por outro lado, nenhum Estado intervencionista possui poder bastante para domesticar o programa do sistema capitalista e nem o Estado de bem-estar social pode dele prescindir.

Frise-se que o Poder Legislativo, no contexto do Estado de bem-estar social, cria a legislação que agasalha esse sistema mediante barganhas e negociações, formando uma legislação estilo "colcha de retalhos" capaz de atender interesses antagônicos: sistema capitalista e Estado de bem-estar social, já que nenhum Estado intervencionista possui poder bastante para domesticar o sistema capitalista no sentido de seu programa e nem o sistema capitalista pode viver sem o Estado social.

A legislação que compõe o Estado de bem- estar social tenta apaziguar antagonismos permanentes, uma dos motivos pelos quais os temas recorrentes do Estado social, em especial aqueles relativos à efetividade dos direitos humanos de segunda geração, serão sempre conflituosos -- razão da importância do Judiciário como único poder capaz de harmonizar esses conflitos. No Estado social, o Judiciário deixa de apresentar um papel de mera adjudicação para assumir uma função conciliatória, ao passo em que se deixa de concentrar tanto no Estado de Direito para focar no Direito como instrumento de mudança $^{91}$

"O Estado social atua com base numa dupla racionalidade: uma, presidida pelo campo da legalidade; outra, orientada pelo cirtério da eficiência. Grande parte da incoerência normativa decorre da estratégia adotada para o equilíbrio dessas racionalidades. Tanto Offe quanto Luhmann, para citar dois exemplos notórios, mencionam a diminuição do grau de precisão das normas (Offe) e o rebaixamento da pretensão de coerência do ordenamento (Luhmann), como a fórmula de superação do conflito entre legalidade e eficiência. As cláusulas gerais, os conceitos jurídicos indeterminados e as normas programáticas, mantendo um formalismo jurídico de fachada, possibilitam uma discricionariedade administrativa e uma politização das reivindicações jurídicas que estão a exigir do magistrado uma versatilidade e uma formação profissional incompatíveis com o que lhe é ensinado nas faculdades de Direito." ${ }^{92}$

De fato, "a partir da transição do regime burocrático-autoritário pós-64 para o regime democrático, ocorrida em 1985, o Judiciário abandona seu comportamento algo

\footnotetext{
${ }^{91}$ CAMPILONGO, Celso Fernandes. op. cit., p. 43 e 50.

${ }^{92}$ Id. Ibid., p. 44.
} 
tímido das décadas anteriores, passando a decidir de modo cada vez mais contundente" ${ }^{\text {. }}$. Suas decisões, fundadas na nova ordem constitucional, têm o impacto de obrigar o Estado a "assumir funções inéditas e por vezes incompatíveis com a estrutura jurídico-política do Estado liberal",94.

Na verdade, a ordem constitucional democrática de 1988 representou uma mudança de paradigma, ao afastar o Estado brasileiro do modelo liberal clássico e moldar as formas de um Estado social. As estruturas normativas do Estado social são teleológicas e hierarquizadas funcionalmente, segundo considerações de caráter axiológico ${ }^{95}$.

A constituição do Estado social faz positivar valores inerentes ao próprio sistema, que devem guiar a atuação de todos os agentes públicos, inclusive - e de maneira especial - a dos juízes. Essa é a única luz que o magistrado tem para guiar sua árdua tarefa de conciliar as contradições inerentes do sistema por meio de um processo hermenêutico.

\subsection{Hermenêutica Constitucional}

\subsubsection{Uma interpretação axiológica}

Nos vinte anos de vigência da Constituição Federal de 1988, assistimos à ascensão do poder judiciário como garantidor dos direitos fundamentais, em especial dos direitos sociais $^{96}$, mas não sem enfrentar inúmeras dificuldades em seu caminho. "Raramente na vida política brasileira, tal como hoje, tem sido tão necessário e urgente entender, em seu pleno sentido axiológico e funcional, a independência da magistratura" ${ }^{\text {"97. }}$.

\footnotetext{
${ }^{93}$ FARIA, José Eduardo. As transformações do Judiciário em face de suas responsabilidades sociais. In: ${ }^{94} \overline{\text { Id. Ibid. }}$ (Org.) Direitos humanos, direitos sociais e justiça, cit., p. 54-55.

${ }^{95}$ CAMPILONGO, Celso Fernandes. op. cit., p. 46.

96،O poder do juiz não está na facilidade da decisão do arbítrio que põe fím ao conflito, o que um computador faz com menor margem de erro e sem o risco da parcialidade nas ao joeirar o direito debatido e exposto na matéria do processo, pacientemente, para resolver o conflito com a realização do valor polar do direito: o justo. A magistratura brasileira, em grande parte, tem perdido a memória dessa dignidade, ora por excesso de trabalho burocrático e fetichismo processual, ora por descuramento do saber jurídico ou por outros motivos. A nova Constituição tem o mérito de convocá-la a exercer o seu papel de poder na atividade de aplicar o direito." SALGADO, Joaquim Carlos. Princípios hermenêuticos dos direitos fundamentais. In: MOREIRA, Luiz; MERLE, Jean-Cristophe (Orgs.). Direito e legitimidade. São Paulo: Landy, 2003. p. 210.

${ }^{97}$ COMPARATO, Fabio Konder. Juízes independentes ou funcionários públicos. Revista da Associação dos Magistrados Brasileiros, v. 2, n. 4, p. 89-93, jan./jun. 1998.
} 
Pressões externas - ou mesmo internas, por parte dos tribunais superiores que se consideram superiores hierárquicos dos juízes de primeira instância - ameaçam a todo momento a independência da atividade jurisdicional ${ }^{98}$.

O Judiciário, de fato, corre o risco de se tornar mero apêndice administrativo do governo $^{99}$, pois, cedendo à burocracia, acabará se desumanizando ${ }^{100}$. E, para que isso não aconteça, faz-se necessário retornar à essência de sua função, qual seja, a de "dizer o direito", isto é, de interpretar o direito posto. É uma atividade essencialmente hermenêutica, portanto, e apenas a correta compreensão dessa dimensão primordial da judicatura é que pode sustentá-la perante os constantes ataques que vem sofrendo.

Hermeneuta do direito por excelência, o juiz tem diante de si dois possíveis caminhos ${ }^{101}$ para a atividade interpretativa: o primeiro, de ordem lógica, resume-se em buscar o sentido adequado do texto normativo de acordo com as regras da sintaxe, e o segundo, de ordem filosófica, orienta essa busca segundo um princípio superior ${ }^{102}$ que lhe aponta os fins.

O primeiro caminho, pretensamente neutro, é mais próprio do cientista do direito que do prático. Mas vale lembrar que "ciência jurídica e experiência jurídica não correm paralelamente, aquela impondo a esta arbitrariamente suas categorias lógicas abstratas"103.

Já o segundo aspecto, o caminho filosófico, marcadamente axiológico ${ }^{104}$, é aquele escolhido pelo operador do direito, que não pode se limitar a uma visão reducionista do fenômeno da vida com o qual trabalha ${ }^{105}$.

${ }^{98}$ COMPARATO, Fabio Konder. Juízes independentes ou funcionário públicos, cit.

${ }^{99}$ Id. Ibid. E, também, SALGADO, Joaquim Carlos. op. cit., p. 210-211.

${ }^{100}$ Cf. ARENDT, Hannah. Eichmann em Jerusalém: um relato sobre a banalidade do mal. São Paulo: Companhia das Letras, 2000.

${ }^{101}$ Cf. KALINOWSKI, Georges. Philosophie et logique d'interprétation en droit. Archives de Philosophie du Droit, Paris, v. 17, p. 39-49, 1972. E também REALE, Miguel. A teoria da interpretação segundo Túlio Ascarelli. Revista de Direito Mercantil, Industrial, Econômico e Financeiro, São Paulo, v. 19, n. 30, p. 7585, abr./jun. 1980.

${ }^{102}$ Quanto aos princípios superiores de interpretação, Salgado os percebe como dois vetores de interpretação: um cultural (axiológico), constituído pelos valores expostos na declaração de direitos, em um Estado de Direito democrático e social; e outro político (ideológico), composto pela lógica de organização econômica do sistema. (SALGADO, Joaquim Carlos. op. cit., p. 206-207).

${ }^{103}$ REALE, Miguel. op. cit., p. 75.

${ }^{104}$ Curiosamente, a percepção do importância do aspecto axiológico do processo interpretativo apenas surgiu em resposta ao aparecimento de um conceito rigoroso, sistêmico e normativo de ordenamento jurídico, a qual permitiu a compreensão de que a Ciência do direito formada por modelos jurídicos prescritivos e hermenêuticos.

${ }^{105}$ “' $U m$ dos objectivos da teoria tridimensional do direito é demonstrar que, sob pena de incidir-se em diversas formas de reducionismo, o jurista, no momento hermenêutica da compreensão das regras jurídicas, não pode fazer abstraç̧ão de como elas se constiruíram, a que razões de facto e a que motivos de valor visaram a atender." (REALE, Miguel. Teoria tridimensional do direito, teoria da justiça, fontes e modelos do direito. Lisboa: Imprensa Nacional Casa da Moeda, 2003. p. 280. (Estudos Gerais, Série Universitária). 
Eis aí, justamente, o "o problema metodológico da interpretação jurídica”, que "deixou-se de conceber-se tão-só e estritamente como interepretação da lei, para se pensar como actus da realização do direito"

Se o direito não mais se identifica meramente com a lei ${ }^{107}$, também o juiz, em sua a atividade interpretativa, deve se lembrar que a "hermenêutica jurídica tem de inserir-se nos princípios superiores do direito. Nesse caso, todas as suas regras e princípios subalternos convergem para a realização do fim supremo do direito: realizar a liberdade." 108

A preponderância do aspecto axiológico no processo de interpretação judicial é evidente, ao percebermos que "uma norma, e notadamente um modelo jurídico, não conserva sempre inalterado o significado ou o sentido com os quais começou a ter vigência, mas pode sofrer alterações semânticas, que a Hermenêutica jurídica atribui à supremacia de mudanças operadas no plano dos factos, dos valores ou de outros processos normativos" $" 109$.

O ordenamento jurídico não é homogêneo e guarda incontáveis conflitos e contradições - de fatos, interesses ou ideias - os quais devem ser resolvidos e superados para a manutenção da ordem. Assim, "prevalece um imperativo axiológico de coerência do ordenamento como um postulado da convivência social" ${ }^{\prime 10}$. De fato, a afirmação de que a lei deve ser interpretada "segundo o seu espírito" equivale a dizer que "o significado real dos modelos jurídicos é o resultado de um processo hermenêutico, consubstanciado em proposições e modelos capazes de revelar-nos o valor ou a razão axiológica do que é preceituado."111

O juiz, ao exercer sua função, não deve ter medo de aplicar esses princípios subjacentes ao texto legal, por julgá-los incompatíveis com a realidade, como pregam aqueles de visão reducionista dos direitos humanos (que a todo momento bradam a "reserva do possível”) e das normas constitucionais (com o mesmo engodo das "normas programáticas"). Os valores eleitos pelo ordenamento devem ser confrontados com a

\footnotetext{
${ }^{106}$ NEVES, António Castanheira. O actual problema metodológico da interpretação jurídica. Coimbra: Coimbra Ed., 2003. v. 1, p. 11.

${ }^{107}$ Id. Ibid., p. 12.

${ }^{108}$ SALGADO, Joaquim Carlos. op. cit., p. 205.

${ }^{109}$ REALE, Miguel. Teoria tridimensional do direito, teoria da justiça, fontes e modelos do direito, cit.

${ }^{110}$ Id. Ibid.

${ }^{111}$ Id. Ibid.
} 
realidade, por meio de uma efetiva realização judicial, pois apenas ela colocará à prova a legitimidade desses valores, ou seja, sua real possibilidade de aplicação.

"Quem procura compreender está sujeito a errar por causa das opiniões prévias, que não se confirmam nas coisas mesmas. Dessa forma, a constante tarefa do compreender consiste em elaborar projetos corretos, adequados às coisas, isto é, ousar hipóteses que só devem ser confirmadas 'nas coisas elas mesmas'. Aqui não há outra 'objetividade' além da elaboração da opinião prévia a ser confirmada. Faz sentido afirmar que o intérprete não vai diretamente ao 'texto', a partir da opinião prévia pronta e instalada nele. Ao contrário, põe à prova, de maneira expressa, a opinião prévia instalada nele a fim de comprovar sua legitimidade, o que significa, sua origem e sua validade" 112

A atividade hermêutica do juiz, eminentemente axiológica, deve, portanto, zelar pela "compatibilidade lógica e ética" do ordenamento jurídico. REALE desenvolve, para tanto, dez modelos hermenêuticos do Direito de caráter metodológico ${ }^{113}$ :

“a) A interpretação das normas jurídicas tem sempre caráter unitário, devendo suas diversas formas ser consideradas momentos necessários de uma unidade de compreensão (Unidade do processo hermenêutico).

b) Toda interpretação jurídica é de natureza axiológica, isto é, pressupõe a valoração objectivada nas proposições normativas (natureza axiológica do acto interpretativo).

c) Toda interpretação jurídica dá-se necessariamente num contexto, isto é, em função da estrutura global do ordenamento (natureza integrada do acto interpretativo).

d) Nenhuma interpretação jurídica pode extrapolar a estrutura objectiva resultante da significação unitária e congruente dos modelos jurídicos positivos (limites objectivos do processo hermenêutico) ${ }^{114}$

e) Toda interpretação é condicionada pelas mutações históricas do sistema, implicando tanto a intencionalidade originária do legislador quanto as exigências fácticas e axiológicas supervenientes, numa compreensão global, ao mesmo tempo retrospectiva e prospectiva(natureza histórico-concreta do acto interpretativo).

f) A interpretação jurídica tem como pressuposto a recepção dos modelos jurídicos como entidades lógicas e axiológicas, isto é, válidos segundo exigências racionais, ainda que a sua gênese possa revelar a presença de fatores alógicos (natureza racional do acto interpretativo).

${ }^{112}$ GADAMER, Hans-Georg. Verdade e método. Petrópolis: Vozes, 2002. v. 2, p. 75.

${ }^{113}$ REALE, Miguel. Teoria tridimensional do direito, teoria da justiça, fontes e modelos do direito, cit., $\mathrm{p}$. 306-307.

114“ $O$ direito a aplicar forma, em todas essas hipóteses [de intederminação], uma moldura dentro da qual existem diversas possibilidades de aplicação, pelo que é conforme ao Direito todo ato que se mantenha dentro deste quadro ou moldura, que preencha esta moldura em qualquer sentido possível. Se por interpretação se entende a fixação da via cognoscitiva do sentido do objeto a interpretar e, consequentemente, o conhecimento das várias que dentro dessa moldura existem". KELSEN, Hans. Teoria pura do direito. Tradução João Batista Machado. São Paulo: Martins Fontes, 2003. p. 390-391. 
g) A interpretação dos modelos jurídicos não pode obedecer a puros critérios da Lógica formal, nem se reduz a uma análise lingüística, devendo desenvolver-se segundo exigências da razão histórica entendida como razão problemática ou conjectural (Problematicismo e razoabilidade do processo hermenêutico).

h) Sempre que for possível conciliá-lo com as normas superiores do ordenamento, deve preservar-se a existência do modelo jurídico (Natureza econômica do processo hermenêutico).

i) Entre as várias interpretações possíveis, optar por aquela que mais corresponde aos valores éticos da pessoa e da convivência social (destinação ética do processo interpretativo).

j) Compreensão da interpretação como elemento constitutivo da visão global do mundo e da vida, em cujas coordenadas se situa o quadro normativo objecto da exegese (Globalidade de sentido do processo hermenêutico)."

\subsubsection{História dos métodos hermenêuticos: do Estado de Direito ao Estado Social}

Um dos traços fundamentais do Estado de Direito liberal clássico foi a fixação de uma ordem estatal, na forma de normas positivas, sujeitas às formalidades que garantiam certeza e segurança - correspondente, como vimos, à primeira fase da etapa da positivação dos direitos humanos. Exigiu-se uma certa formalidade constitucional e as constituições puderam se submeter às regras usuais de interpretação.

Na tradição do século XIX, conforme as lições de Savigny e outros autores clássicos, as regras de interpretação correspondiam à fixação do método vocabular (gramatical), proposicional (método lógico), genético (método histórico) e global (método sistemático). A interpretação, voltada para o Estado de Direito concebido como um estado mínimo, reduzido em suas funções, "a interpretação tinha uma função de bloqueio" conforme princípios de legalidade e da estrita legalidade como peças fundantes da constitucionalidade $^{115}$.

Todavia, a norma constitucional contém elementos jurídicos que a diferenciam das demais normas, características da qual um normativismo rigorosamente positivista, supostamente neutro e acrítico, não chega a dar conta.

No atual statu quo, verificamos a desformalização da constituição (da hermenêutica tradicional - procedimentos interpretativos de bloqueio - e procedimentos

\footnotetext{
${ }^{115}$ FERRAZ JUNIOR, Tércio Sampaio. op. cit., p. 11.
} 
interpretativos de legitimação de aspirações sociais à luz da constituição). Se a constituição apresenta, no seu corpo normativo, um sistema de valores, aplicação das normas, por via interpretativa, se torna uma realização de valores. Com isso, o procedimento hermenêutico de captação do sentido do conteúdo das normas transforma-se em um entendimento de compreensão valorativa conforme procedimentos próprios da análise e ponderação de valores.

Quando se opõem procedimentos interpretativos de bloqueio e procedimentos de legitimação, o que entra em pauta não é a crítica ao positivismo ou a defesa de que o direito é um fenômeno cultural, mas de como captar o sentido das constituições no momento em que, concebidas estas como um sistema de valores, a hermenêutica se transforma num instrumento de realização política, com base na qual a legislação procurará concretizar princípios e programas agasalhados pelo texto constitucional. A hermenêutica deixa de ser um problema de correta subsunção do fato à norma - com sua carga histórica, lógica, sistemática, teleológica e valorativa, para se tornar um problema de conformação política dos fatos, isto é, de sua transformação consoante um projeto ideológico. ${ }^{116}$

Essa transformação corresponde à superação do Estado de Direito burguês, que as constituições abandonam ou alteram. Tal forma pressupunha uma distinção entre Estado e Sociedade como entidades autônomas, o que obrigava as constituições a circunscreverem-se a regras gerais e limitativas da atividade do Estado. Agora, as tarefas do Estado se multiplicaram e modificaram, exigindo do Estado a conformação social adequada da sociedade; são colocadas para ele outras funções que não se casam plenamente com os tradicionais limites do Estado de Direito. ${ }^{117}$

As exigências postas ao Estado Social pressupõem que o intérprete esteja autorizado a articular e a qualificar o interesse público, coletivo, individual, posto como um objetivo pelo preceito constitucional, o que implica, uma certa "discricionariedade hermenêutica". 118

\footnotetext{
${ }^{116}$ FERRAZ JUNIOR, Tércio Sampaio. op. cit., p. 13.

${ }^{117}$ Id. Ibid.

${ }^{118}$ Id. Ibid.
} 
Os preceitos dirigidos à prestação positiva do Estado Social são leges imperfectae, "não imediatamente realizáveis sem a atuação do próprio hermeneuta, que deve promover uma identificação dos meios possíveis à consecução de finalidades"119.

Os reguladores dogmáticos de uma interpretação de legitimação são, portanto, um pouco abertos e flexíveis, como ocorre na regra da proporcionalidade. $\mathrm{Na}$ linguagem jurídica aplicar a norma significa colocá-la em contato com um referente objetivo (atos e fatos). A aplicabilidade exige, assim, interpretação.

A importância crescente do Estado Social no seio do constitucionalismo forçou o recrudescimento da questão da eficácia, posto que a atribuição ao Estado de responsabilidades impôs o crescimento de normas programáticas e, em conseqüência, a reflexão sobre a chamada eficácia técnica.

Eficácia é um termo jurídico que permite ao jurista um controle sobre os efeitos do Direito. O crescimento da forma típica do Estado Social no seio da forma típica do Estado de Direito fez surgir, ao lado da interpretação de bloqueio, a "interpretação de legitimação". ${ }^{120}$

Com a passagem do Estado liberal para o Estado social, surge a técnica jurídica que faz distinção entre regras e princípios, os quais passam a ter renovado valor nas constituições de caráter social da atualidade.

\subsubsection{Regras e princípios}

O conceito de princípio - do latim principius, que quer dizer "começo" e que guarda relação etimológica com primus "primeiro" - implica a negação de anterioridade. Isso não quer dizer que nada exista antes do princípio. O ponto, enquanto ponto, é o princípio absoluto da linha. Isso não quer dizer que não existam pontos anteriores, mas que esses são princípios de outros seguimentos ou outras linhas e não daquela que estamos tratando. Portanto, princípio é aquilo que não está depois de outro,

\footnotetext{
${ }^{119}$ FERRAZ JUNIOR, Tércio Sampaio. op. cit., p. 14.

${ }^{120}$ Id. Ibid.
} 
como expressa o Evangelho de São João "No princípio era o Logos e o Logos estava em Deus". ${ }^{121}$

Na teoria jurídica contemporânea os princípios são considerados normas jurídicas de impositividade e abstração. A norma é gênero do qual a regra e o princípio são espécies, que se distinguem entre si pelo grau de densidade normativa. Quando adentram as Constituições os princípios ganham patamar constitucional, o que os torna fundamento do sistema jurídico. ${ }^{122}$

A Constituição brasileira é um documento legal que reflete tanto o que nós somos enquanto sociedade, como o que nós queremos ser $^{123}$. Desde o seu Preâmbulo, projeta a construção de um Estado Democrático de Direito, "destinado a assegurar o exercício dos direitos sociais e individuais, a liberdade, a segurança, o bem-estar, o desenvolvimento, a igualdade e a justiça como valores supremos de uma sociedade fraterna, pluralista e sem preconceitos (...)".

Nossa Constituição apresenta princípios que assinalam os objetivos e fundamentos do nosso Estado, constituindo a viga mestre da fundação normativa e, portanto, a fonte primária de toda tarefa interpretativa ${ }^{124}$. Princípios, como ensina Alexy, são regras que ordenam que alguma coisa seja realizada na maior medida possível; são mandados de otimização, caracterizados pelo fato de que podem ser cumpridos em vários graus e que a medida apropriada de seu cumprimento depende não só do que é factualmente possível, mas também do que é juridicamente possível. ${ }^{125}$

Os direitos humanos não são um dado, mas um construído, uma invenção humana, em constante processo de construção e reconstrução ${ }^{126}$, compondo- de uma unidade indivisível, interdependente e inter-relacionada, capaz de conjugar o catálogo de direitos civis e políticos as catálogo de direitos sociais, econômicos e culturais, porque só o reconhecimento integral de todos esses direitos pode assegurar a existência real de cada um

\footnotetext{
${ }^{121}$ SANTOS, Mario Ferreira dos. Métodos lógicos e dialéticos. 3. ed. São Paulo: Logos, 1959. v. 1, p. 20.

${ }^{122}$ ESPÍNDOLA, Ruy Samuel. Conceito de princípios constitucionais. 2. ed. São Paulo: Ed. Revista dos Tribunais, 2002. p. 33-35.

${ }^{123}$ PIOVESAN, Flávia. Direitos humanos e o princípio da dignidade da pessoa humana, dos princípios constitucionais considerações em torno das normas principiológicas da Constituição. São Paulo: Malheiros Ed., 2003. p. 181-197.

${ }^{124}$ Id. Ibid.

${ }^{125}$ ALEXY, Robert. A theory of constitucional rights. Translated by Julian Rivers. Oxford: Oxford University Press, 2004. p. 47-48.

${ }^{126} \mathrm{Cf}$. ARENDT, Hannah. As origens do totalitarismo, cit.
} 
deles. Nesse contexto, exsurge o princípio da dignidade humana como o verdadeiro princípio "inicial”, a norma maior da orientação interpretativa. ${ }^{127}$

Realmente, é preciso transpor a fronteira da reflexão filosófica, ingressar na prática jurisprudencial e produzir efeitos positivos sobre a realidade, concretizando os princípios constitucionais. $^{128}$

No caso dos direitos humanos sociais, podemos dizer que as normas constitucionais, por seu conteúdo aberto, principiológico e extremamente dependente da realidade subjacente, não possuem um sentido único e objetivo. O relato dessa norma demarca uma moldura dentro da qual se desenham diferentes possibilidades interpretativas, cujo sentido será determinado à vista dos elementos do caso concreto e dos princípios a serem preservados, bem como dos fins a serem realizados. ${ }^{129}$

Podemos dizer que a juridicidade ou normatividade dos princípios passou por três distintas fases: a jusnaturalista, a positivista e a pós-positivista.

O jusnaturalismo moderno começa a formar-se a partir do século XVI, procurando superar o Dogmatismo medieval e distanciar-se do ambiente teológico em que se desenvolveu. Aproximando a lei da razão e dando substrato jurídico às duas grandes conquistas do mundo moderno: a tolerância religiosa e a limitação do poder do Estado, o direito natural é embasado na crença da existência de valores e de pretensões humanas legítimas que não decorrem de uma norma emanada do Estado. Essa crença foi fruto dos trunfos ideológicos da burguesia e o combustível das revoluções liberais. ${ }^{130}$

O advento do Estado Liberal, a consolidação dos ideais constitucionais em textos escritos e o êxito da codificação simbolizaram a vitória do direito natural. No início

\footnotetext{
${ }^{127}$ Neste sentido, ARENDT, Hannah. As origens do totalitarismo, cit., p. 332 "Os crimes contra os direitos humanos, especialmente dos regimes totalitários, podem sempre justificar-se pela desculpa de que o direito equivale ao que é bom ou útil para um todo, em contraste com as suas partes. (O lema de Hitler, de que "o direito é aquilo que é bom para o povo alemão", é apenas uma forma vulgar de uma concepção da lei que pode ser encontrada em toda parte e que, na prática, só não permanecerá eficaz se as tradições mais antigas, ainda em vigor nas constituições, o evitarem.). Uma concepção de lei que identifica o direito com a noção do que é bom - para o indivíduo, ou para família, ou para o povo, ou para a maioria- torna-se inevitável quando as medidas absolutas e transcedentais da religião ou da lei da natureza perdem a sua autoridade. $\mathrm{E}$ essa situação de forma alguma se resolverá pelo fato de ser a humanidade a unidade à qual se aplica o que é "bom". Pois é perfeitamente concebível, e mesmo diante das possibilidades políticas práticas, que, um belo dia, uma humanidade altamente organizada e mecanizada chegue, de maneira democrática, - isto é, por decisão da maioria- à conclusão de que, para a humanidade como um todo, convém liquidar certas partes de si mesma".

${ }^{128}$ BARROSO, Luis Roberto; BARCELLOS, Ana Paula. A nova interpretação constitucional: ponderação, argumentação e papel dos princípios. In: LEITE, George Salomão (Org.). Dos princípios constitucionais: considerações em torno das normas principiológicas da Constituição. São Paulo: Malheiros Ed., 2003.

${ }^{129}$ Id. Ibid.

${ }^{130}$ Id. Ibid.
} 
do século XIX, os direitos naturais, haviam se incorporado de forma generalizada aos ordenamentos positivos e já não traziam mais a revolução, mas a conservação. A fase jusnaturalista posiciona os princípios jurídicos em esfera abstrata e metafísica. Reconheceos como inspiradores de um ideal de justiça, cuja eficácia se cinge a uma dimensão éticovalorativa do Direito, com normatividade quase nula. ${ }^{131}$

Considerado metafísico e acientífico, o jusnaturalismo foi empurrado para margem da História pelo positivismo do século XIX, fruto de uma grande crença no poder do conhecimento científico.Sua importação para o Direito resultou na busca de objetividade científica, com ênfase na realidade observável e não na especulação filosófica e na separação de Direito da Moral: surgiu, assim, o Positivismo Jurídico.

A Ciência do Direito, como as demais, deveria fundar-se em juízos de fato, que visam ao conhecimento da realidade e não em juízos de valor, que representam uma tomada de posição diante da realidade. Nessa fase juspositivista, os princípios entram nos Códigos como fonte subsidiária da inteireza dos textos legais. São encaradas como "válvulas de segurança que garantem o reinado absoluto da lei", no dizer de Gordillo Cañas. Não são encarados como superiores às leis, mas delas deduzidos, para suprirem os vazios normativos que elas não puderam prever. $\mathrm{O}$ valor dos princípios está no fato de derivarem das leis, e não de um ideal de justiça. ${ }^{132}$

O positivismo, pretendendo ser uma Teoria do Direito, resultou em uma ideologia do Direito, tornando-se não só o modo de entender o Direito, mas de querer o Direito.Podemos dizer que o fetiche da lei e do positivismo acrítico serviu de disfarce para autoritarismos de matizes variados.

Sem embargo da resistência filosófica e de outros movimentos influentes nas primeiras metades do século XX, a decadência do positivismo é emblematicamente associada à derrota do Fascismo na Itália e do Nazismo na Alemanha.

Nesse contexto, a superação histórica do jusnaturalismo e o fracasso do positivismo abriram caminho para um conjunto amplo e inacabado de reflexões acerca do Direito, sua função social e sua interpretação: o Pós-Positivismo.

Com efeito, o Pós- Positivismo é um ideário difuso, no qual se incluem a definição das relações entre valores, princípios e regras, aspectos da chamada Nova

\footnotetext{
${ }^{131}$ ESPÍNDOLA, Ruy Samuel. op. cit.

${ }^{132}$ Id. Ibid.
} 
Hermenêutica Constitucional, e a teoria dos direitos fundamentais, edificada sobre o fundamento da dignidade da pessoa humana. A valorização dos princípios, sua incorporação, explícita e implícita, pelos textos constitucionais e o reconhecimento pela ordem jurídica de sua normatividade fazem parte desse ambiente de reaproximação de Ética e Direito. ${ }^{133}$

Nessa fase, os princípios, que passam a ser positivados nos textos constitucionais conquistam a dignidade de normas jurídicas vinculantes, vigentes e eficazes e passam a assentar os principais padrões pelos quais se investiga a compatibilidade da ordem jurídica aos princípios fundamentais de estalão constitucional, aos princípios que dão fundamento axiológico e normativo ao ordenamento jurídico. ${ }^{134}$

A Dogmática moderna avaliza o entendimento de que as normas em geral, e as normas constitucionais em particular, enquadram-se em duas categorias diversas: os princípios e as regras. Normalmente as regras contêm relato mais objetivo, com incidência restrita às situações específicas às quais se dirigem. Já os princípios têm maior teor de abstração e incidem sobre uma pluralidade de situações. ${ }^{135}$

Para o positivismo legalista, as normas se cingiam à regras jurídicas. Todavia, a mudança de paradigma nessa matéria deve especial tributo às concepções de Ronald Dworkin e as desenvolvimentos a ela dados por Robert Alexy, no sentido de formular uma distinção qualitativa entre regra e princípio. ${ }^{136}$

Regras são normalmente relatos objetivos, descritivos de determinadas condutas aplicáveis a um conjunto limitado de situações. Ocorrendo a hipótese prevista no seu relato, a regra deve incidir, pelo mecanismo da subsunção: enquadram-se os fatos na previsão abstrata e produz-se uma conclusão. A aplicação de uma regra se opera na modalidade tudo ou nada: ou ela regula a matéria em sua inteireza ou é descumprida. $\mathrm{Na}$ hipótese de conflito entre duas regras só uma delas irá prevalecer. Princípios contêm relatos com maior grau de abstração, não especificam a conduta a ser seguida e se aplicam a um conjunto amplo, por vezes indeterminados, de situações. Em uma ordem democrática os princípios entram em tensão dialética, apontando direções diversas. Por essa razão, sua aplicação deverá se dar mediante ponderação. Sua aplicação não será tudo-ou nada, mas graduada à vista das circunstâncias representadas por outras normas ou situações de fato.

\footnotetext{
${ }^{133}$ BARROSO, Luis Roberto; BARCELLOS, Ana Paula. op. cit.

${ }^{134}$ ESPÍNDOLA, Ruy Samuel. op. cit.

${ }^{135}$ BARROSO, Luis Roberto; BARCELLOS, Ana Paula. op. cit.

${ }^{136}$ Id. Ibid.
} 
Sem embargo da multiplicidade de concepções na matéria, há pelo menos um consenso sobre o qual trabalha a doutrina em geral: princípios e regras desfrutam igualmente do status de norma jurídica e integram, sem hierarquia, o sistema referencial do intérprete. Dos múltiplos critérios distintivos possíveis, três deles são aqui destacados: (1) o conteúdo; (2) a estrutura normativa; (3) as particularidades da aplicação.

Quanto ao conteúdo, destacam-se os princípios como normas que identificam valores a serem preservados ou fins a serem alcançados. Trazem em si, normalmente, um conteúdo axiológico ou uma decisão política.

As regras limitam-se a traçar uma conduta. A questão relativa a valores ou a fins públicos não vem explicitada na norma porque já foi decidida pelo legislador, e não transferida ao intérprete.

Com relação à estrutura normativa, tem-se que o relato de uma regra especifica os atos a serem praticados para seu cumprimento adequado. A aplicação de uma regra não envolve um processo de racionalização mais sofisticado. Se ocorre o fato previsto em abstrato, produz-se o efeito concreto prescrito. Já os princípios indicam fins, estados ideais a serem alcançados. Como a norma não detalha a conduta a ser seguida para a sua realização, a atividade do intérprete será mais complexa, pois a ele caberá definir a ação a tomar.

Quanto ao modo ou particularidades de sua aplicação, a doutrina que se desenvolveu sobre as premissas teóricas de Dworkin e Alexy traça a distinção entre princípios e regras. Regras são proposição normativas aplicáveis sob a forma de tudo ou nada (all-or-nothing). Sua aplicação se dá, predominantemente, mediante subsunção.

Princípios contêm, normalmente, uma maior carga valorativa, um fundamento ético, uma decisão política relevante, e indicam uma determinada direção a seguir. Por isso sua incidência não pode ser posta em termos de tudo-ou-nada, de validade ou invalidade. A aplicação dos princípios se dá, predominantemente, mediante ponderação.

A nova interpretação constitucional assenta-se em um modelo de princípios, aplicáveis mediante ponderação, cabendo ao intérprete proceder à interação entre fato e norma e realizar escolhas fundamentadas, dentro das possibilidades e limites oferecidos pelo sistema jurídico, visando à solução justa para o caso concreto. Nessa perspectiva póspositivista do Direito, são ideias essenciais a normatividade dos princípios, a ponderação de valores e a teoria da argumentação. 


\section{COMO DECIDE O JUIZ BRASILEIRO?}

\subsection{Um trabalho de observação}

Nosso trabalho busca analisar o modus operandi do magistrado brasileiro diante dos casos que lhes são submetidos e sua repercussão sobre a eficácia dos direitos humanos sociais. É um parar para pensar sobre o que estamos fazendo, por meio de um método experimental e de observação.

Feita uma breve incursão teórica sobre o fascinante campo da hermenêutica dos direitos fundamentais, passamos agora da teoria para a prática, para que possamos perceber o descompasso entre os mundos do dever-ser e do ser, para, por fim, sempre com os pés pregados ao chão, podermos propor soluções concretas para os juízes que temos.

Nossa pesquisa, lastreada na experiência de mais de quinze anos de exercício da magistratura, tem um viés essencialmente empírico e, para tanto, utilizamos, sobretudo, fontes primárias - sentenças e acórdãos - consultados a partir do banco de dados eletrônicos do Conselho da Justiça Federal, que, em setembro de 2007, contava com uma seleção de 1.252.654 acórdãos. Os casos apresentados foram selecionados em função do tipo e repetição do raciocínio do magistrado, possibilitando a identificação de aspectos comuns ao discurso decisório do judiciário brasileiro contemporâneo, registrando acertos e desacertos, bem como suas implicações na concretização dos direitos humanos sociais.

Percebemos também que os juízes brasileiros, soterrados sob montanhas de autos de processos, sempre que possível, esquivam-se por formalidades processuais. Essa característica é ainda mais grave nos tribunais superiores. Não foi, portanto, tarefa simples encontrar acórdãos relevantes para nossa pesquisa, nos quais os magistrados se alongassem e permitissem detalhada análise de sua forma de raciocinar. Releva notar que os casos selecionados não versam, todos eles, sobre direitos humanos sociais, porque o objetivo de nossos estudos é visualizar, tanto quanto possível, os paradigmas expressos e ocultos do raciocínio do magistrado na hora de sua decisão, razão da seleção em função da repetição do tipo de raciocínio e não do tema de direito discutido. 
Contamos com a paciência do leitor, que se deparará com longos trechos extraídos dos acórdãos em exame - excertos necessários, por exigência da natureza empírica e analítica deste trabalho.

Deixemos portanto, de mais prolegômenos, e passemos à análise jurisprudencial.

\subsection{O peso das pressões sociais $\left(\mathrm{HC} \mathrm{n}^{0} 56.975 / \mathrm{PA}\right)$}

\subsubsection{Análise do caso}

Analisaremos o habeas corpus impetrado por Jorge Luiz de Moura Andrade em favor de Dirceu Milani, Cleudimar Soares Milani, Luís Fernando Bertol e Ricardo Breier contra as Câmaras Criminais Reunidas do Tribunal de Justiça do Pará, que confirmou a prisão preventiva decretada pelo magistrado de primeira instância. A Turma do STJ, por unanimidade, conheceu parcialmente o habeas corpus e concedeu a ordem, nos termos do voto da Sra. Ministra Relatora. Os Srs. Ministros Hamilton Carvalhido, Paulo Gallotti e Paulo Medina votaram com a Relatora.

O caso pode ser assim resumido: os pacientes foram denunciados por suposta infração aos artigos 171, caput, 299 e 288, do Código Penal; 67 c/c 76, incisos II, III e IV, alíneas "a" e "v", da Lei 8.07890; 7º, inciso VII, da Lei n. 8.137/90. Decretada a prisão preventiva, arrimada no resguardo da ordem pública e da instrução criminal, demandou-se junto ao juízo monocrático a revogação da constrição, pedido que foi indeferido.

Narra a impetração que os pacientes não apresentam qualquer periculosidade ou oferecem ameaça à paz social e à segurança pública, restando, portanto, carente de motivação a segregação imposta. Afirma, ainda, que os pacientes são Diretores e representantes de diversas instituições educacionais, as quais se encontram em perfeito funcionamento, além de regularmente instaladas em sedes próprias e inscritas nos órgãos estaduais e federais competentes. Aduz, finalmente, que serviu de embasamento para o oferecimento da denúncia procedimento interno do Ministério Público, no qual não foi 
dada aos pacientes oportunidade de defesa; o que teria, como consequência, acarretado a nulidade de tal feito, bem como do processo penal.

O Juiz de primeira instância decretou a prisão preventiva justificando-a nos seguintes termos (grifos nossos):

"Ao que tudo indica, o crime em estudo tem sido praticado ao longo de vários anos, em vários Estados, sem que jamais tenha tido qualquer reprimenda. Ora, o estelionato é um crime covarde, pois o agente se vale da confiança ou inocência da vítima para obter o que almeja, subtraindolhe não apenas bens materiais, mas também infundindo-lhe a crença de que qualquer desconhecimento é, antes de tudo, um inimigo.

Num momento em que toda sociedade clama por paz e justiça, o que menos se precisa é que casos como o que ora se estuda ocorram, por isso uma resposta rígida e imediata do judiciário é necessária não apenas para abrandar a amargura que fatalmente encherá os corações daqueles que foram ludibriados, mas também para que a comunidade saiba que se o crime é, por vezes, inevitável, a impunidade nunca o é. Assim, a segregação provisória dos representados apresenta-se necessária para a garantia da ordem pública.

Quanto ao risco de que a liberdade dos representados crie risco para a instrução do processo penal e para a futura aplicação da lei penal, faço minhas as ponderações do Ministério Público quando afirma que 'pela facilidade de deslocamento territorial dos chefes da organização, viabilizada pela diversidade espacial de atuação e poder econômico do grupo, é certo que seus líderes evadir-se-ão do distrito da culpa, prejudicando a apuração, processamento e punição das condutas ilícitas; finalmente, deve ser lembrado que os crimes, em tese, praticados pelos representados são apenas com reclusão, havendo, portanto, extrema necessidade da medida a acauteladora para garantia da ordem pública, por conveniência da instrução criminal e aplicação da lei penal".

E mais adiante:

"Portanto, sendo relevantes estas razões fundamentadas para se decretar a prisão preventiva, daí, logicamente que nenhuma ilegalidade decorre do ato, sobretudo em face da prova inequívoca produzida da existência do crime, em tese, assim como há indícios suficientes da autoria.

(...) Assim, vislumbro a ocorrência das hipóteses ensejadoras da prisão preventiva, uma vez que existe ameaça à ordem pública, restando demonstrado que os pacientes irão dificultar o desenrolar da instrução processual, obstaculizando, em conseqüência, a aplicação da lei penal."

O impetrante pediu, liminarmente, a concessão de "salvo-conduto" em favor dos pacientes. No mérito, pleiteou a confirmação da liminar e o trancamento da ação penal. Ao analisar o habeas corpus, o STJ proferiu a seguinte decisão: 
PROCESSO PENAL. HABEAS CORPUS. PEDIDOS NÃO FORMULADOS EM INSTÂNCIA INFERIOR. CONHECIMENTO. IMPOSSIBILIDADE. PRISÃO PREVENTIVA. FUNDAMENTAÇÃO. AUSENNCIA.

1. Pedidos não formulados em instância inferior não podem ser apreciados nesta Corte, sob pena de indevida supressão de instância.

2. A prisão processual cumpre função instrumental, não podendo servir como antecipação de pena.

3. Ordem conhecida em parte e, nesta extensão, concedida.

Muito bem. O tema principal a ser analisado nesse caso é a legalidade da prisão preventiva decretada pelo magistrado de primeiro grau e confirmada pelo Tribunal de Justiça do Pará, bem como o raciocínio por ele desenvolvido. Vejamos:

"Num momento em que toda sociedade clama por paz e justiça, o que menos se precisa é que casos como o que ora se estuda ocorram, por isso uma resposta rígida e imediata do judiciário é necessária não apenas para abrandar a amargura que fatalmente encherá os corações daqueles que foram ludibriados, mas também para que a comunidade saiba que se o crime é, por vezes, inevitável, a impunidade nunca o é. Assim, a segregação provisória dos representados apresenta-se necessária para a garantia da ordem pública.

Quanto ao risco de que a liberdade dos representados crie risco para a instrução do processo penal e para a futura aplicação da lei penal, faço minhas as ponderações do Ministério Público quando afirma que "pela facilidade de deslocamento territorial dos chefes da organização, viabilizada pela diversidade espacial de atuação e poder econômico do grupo, é certo que seus líderes evadir-se-ão do distrito da culpa, prejudicando a apuração, processamento e punição das condutas ilícitas".

Finalmente, deve ser lembrado que os crimes, em tese, praticados pelos representados são apenados com reclusão, havendo, portanto, extrema necessidade da medida acauteladora para garantia da ordem pública, por conveniência da instrução criminal e aplicação da lei penal.".

Analisando o referido discurso decisório, a Sra. Ministra Maria Thereza de

Assis Moura redirecionou o raciocínio delineado pelo juiz, citando inúmeros precedentes do STJ, nos seguintes termos:

"Em primeiro lugar, independentemente da repercussão do caso, o julgador deve respeitar o devido processo legal, não podendo atropelar o procedimento legalmente estatuído. Para que o provimento jurisdicional seja justo, devemos atentar para as garantias constitucionais que funcionam como refúgio último de dignidade da pessoa, como adverte EROS ROBERTO GRAU (O Direito posto e o direito pressuposto, São Paulo, Malheiros, 2005, pp. 168-169). 
A prisão processual não pode se prestar ao papel de antecipação de pena, sob a roupagem de guarida da ordem pública, como se depreende da estrutura do discurso judicial de primeiro grau. (grifo nosso)

Ordem pública é fundamento geralmente invocável, sob diversos pretextos, para se decretar a preventiva, fazendo-se total abstração de que esta é uma coação cautelar e, sem cautelaridade, não se admite, à luz da Constituição, prisão provisória.

Comoção social, perigosidade do réu, crime perverso, insensibilidade moral, os espalhafatos da mídia, reiteradas divulgações pela rádio e pela televisão, credibilidade da Justiça, idiossincrasia do Juiz por este ou aquele crime, tudo, absolutamente tudo, ajusta-se à expressão genérica ordem pública. E como sabe o Juiz que a ordem pública está perturbada, a não ser pelo noticiário?

Os jornais, sempre que ocorre um crime, o noticiam. E não é pelo fato de a notícia ser mais ou menos extensa que pode caracterizar a perturbação da ordem pública sob pena de essa circunstância ficar a critério da mídia. $\mathrm{Na}$ maior parte das vezes, é o próprio Juiz ou o órgão do Ministério Público que, como verdadeiros sismógrafos mensuram e valoram a conduta criminosa proclamando a necessidade de garantir a ordem pública, sem nenhum, absolutamente nenhum, elemento de fato, tudo ao sabor de preconceitos e da maior ou menor sensibilidade desses operadores da Justiça. E a prisão preventiva, nesses casos, não passará de uma execução sumária. Decisão dessa natureza é eminentemente bastarda, malferindo a Constituição da República. O réu é condenado antes de ser julgado. E se for absolvido? Ainda que haja alguma indenização, o anátema cruel da prisão injusta ficará indelével para ele, sua família e o círculo da sua amizade (TOURINHO FILHO, Fernando da Costa, Manual de processo penal, São Paulo, Saraiva, 2006, pp. 614615).

A facilidade de deslocamento dos pacientes também não seria fundamento para a prisão preventiva. Ao contrário, pondera a Ministra Relatora, todos aqueles que tivessem uma ocupação que envolvesse viajar, teriam, automaticamente, militando contra si a presunção de que estariam, se investigados, a colocar em risco a aplicação da lei penal. Ademais, não se verificou um dado concreto a evidenciar que os pacientes estariam para se evadir, como venda de bens de raiz, renovação de passaporte ou compra de passagens para localidades de fronteira. E, se agora, encontram-se em local incerto, tal não pode militar em seu desfavor, pois, pesa contra eles mandado de prisão desligado de concretas referências ao constante no art. 312 do Código de Processo Penal”.

Analisemos o discurso decisório do juiz de primeiro grau, confirmado pelo Tribunal de Justiça do Pará, e o da relatora do habeas corpus no STJ, para identificarmos o raciocínio articulado por um e pelo outro e as suas consequiências no campo do direito.

O primeiro magistrado iniciou o raciocínio fixando uma determinada premissa maior: os anseios da sociedade e a impunidade. "Ao que tudo indica, o crime em 
estudo tem sido praticado ao longo de vários anos, em vários Estados, sem que jamais tenha tido qualquer reprimenda.[...]". E, mais adiante, "Num momento em que toda sociedade clama por paz e justiça, o que
menos se precisa é que casos como o que ora se estuda ocorram, por isso
uma resposta rígida e imediata do judiciário é necessária não apenas para
abrandar a amargura que fatalmente encherá os corações daqueles que
foram ludibriados, mas também para que a comunidade saiba que se o
crime é, por vezes, inevitável, a impunidade nunca o é. [...]".

A Ministra relatora, por sua vez, iniciou o discurso decisório fixando os princípios constitucionais como premissa maior:

\begin{abstract}
"Em primeiro lugar, independentemente da repercussão do caso, o julgador deve respeitar o devido processo legal, não podendo atropelar o procedimento legalmente estatuído. Para que o provimento jurisdicional seja justo, devemos atentar para as garantias constitucionais que funcionam como refúgio último de dignidade da pessoa, como adverte EROS ROBERTO GRAU (O Direito posto e o direito pressuposto, São Paulo, Malheiros, 2005, pp. 168-169). A prisão processual não pode se prestar ao papel de antecipação de pena, sob a roupagem de guarida da ordem pública, como se depreende da estrutura do discurso judicial de primeiro grau[...]"
\end{abstract}

Verificamos, nesse caso, que a decisão do juiz de primeiro grau, confirmada pelo Tribunal de Justiça do Pará, não surgiu após um procedimento silogístico. Em primeiro lugar houve a decisão. Depois, tentou justificá-la com um certo discurso jurídico. Também observamos que ele não usou um silogismo de fachada para camuflar os reais motivos da sua decisão; a motivação é clara: os réus são culpados e precisam ser punidos. Nesse contexto, a resposta do judiciário deve ser rígida e rápida.

Os reais motivos que o levaram a decidir assim - pressão institucional decorrente da opinião de outros magistrados, possibilidade de recurso ou mesmo pressões externas da imprensa nunca serão revelados. Inferimos, contudo, que ele apenas racionalizou a posteriori uma decisão já tomada. Se ele tivesse raciocinado silogisticamente, fazendo figurar o princípio constitucional da presunção de inocência como premissa maior, a conclusão, no caso, seria outra.

A conclusão também seria outra se ele houvesse tomado a decisão culpabilidade dos réus- mas tivesse seguido o raciocínio silogístico somente para justificála por imposição constitucional e processual, porque, nesta hipótese, teria que afastar o princípio da presunção de inocência e do devido processo legal, que servem como válvula 
de segurança para o acusado. Precisamos impedir que certos apriorismos ou certos preconceitos possam modelar a realidade mais ao nosso sabor do que demonstrar a realidade independente de nós. Distinguir quando a realidade é a projeção da nossa mente ou quando a realidade é testemunho de si própria é a tarefa mais difícil de ser realizada pelo juiz. $^{137}$

\subsubsection{Silogismo revisitado: por um silogismo crítico e axiológico}

No que diz respeito à redução do processo decisório a um silogismo, Tercio Sampaio Ferraz Junior entende que essa construção o empobrece e não revela sua maior complexidade. ${ }^{138}$ Katharina Sabota também defende um ceticismo forte com relação a toda sustentação teórica de cunho lógico-dedutivo. Para ela, o uso estratégico derivado de formas silogísticas atribuída às regras jurídicas seria apenas uma forma de camuflar a verdadeira rede de regularidades que são produzidas pelas ações que elas próprias regulam. ${ }^{139}$ Para Gadamer, a interpretação da lei é simplesmente uma tarefa criativa ${ }^{140}$, ou seja, o conhecimento da norma passa pela compreensão da mesma, não como um exercício de mera apreensão da dogmática jurídica, mas da interpretação criativa, crítica, na qual o sujeito, determinado por sua cultura, será capaz de dar conta da interpretação como processo de compreensão do Direito ${ }^{141}$. Para ele, a relação sujeito-objeto na interpretação jurídica não é meramente contemplativa, em que a dogmática jurídica se apresenta como verdade absoluta, quase como verdade revelada, mas uma atividade subjetiva na qual o sujeito tem papel ativo, mesmo considerando que grande parte da interpretação só pode ser realizada mediante conceitos previamente estabelecidos na cultura e na tradição na qual se encontra inserido $^{142}$. Neil MacCormick defende o silogismo enquanto método dedutivo, concluindo que, institucional e psicologicamente, o juiz estaria adstrito aos argumentos lógicos obtidos de maneira dedutiva, a partir das normas e dos fatos. No entanto, mesmo

\footnotetext{
${ }^{137}$ Cf. SANTOS, Mario Ferreira dos. op. cit.

${ }^{138}$ FERRAZ JUNIOR, Tércio Sampaio. op. cit., p. 316.

${ }^{139}$ SOBOTA, Katharina. Não mencione a norma! Tradução João Maurício Adeodato. Anuário dos Cursos de Pós-Graduação em Direito, Recife, n. 7, p. 251-273, 1995.

${ }^{140}$ GADAMER, Hans-Georg. op. cit.

${ }^{141}$ PARINI, Pedro. O raciocínio dedutivo como possível estrutura lógica da argumentação judicial: silogismo versus entimema a partir da contraposição entre as teorias de Neil MacCormick e Katharina Sobota. In: CONGRESSO DO CONSELHO NACIONAL DE PESQUISA E PÓS-GRADUAÇÃO EM DIREITO, 14. 2006, Fortaleza. Anais... Florianópolis: Fundação Boiteux, 2006.

${ }^{142}$ GADAMER, Hans-Georg. Gadamer in conversation: reflections and commentary. Translated by Richard Palmer. New Haven: Yale University Press, 2001. p. 41.
} 
reforçando que a lógica dedutiva é de extrema relevância para justificação, MacCormick admite que é possível que o juiz decida contra a inferência lógica, não se justificando em normas jurídicas, mas em normas morais. E, mais gravemente, em determinados casos em que a conclusão lhe seja inconveniente, o juiz, por seu profundo conhecimento das regras processuais, pode simplesmente não aceitar a validade das premissas menores, considerando que não há prova suficiente dos fatos ${ }^{143}$.

Essas concepções que apreendem uma parte da realidade e vêem apenas um dos fenômenos da decisão judicial e não a sua completude, de forma que todas elas estão igualmente corretas. ${ }^{144}$ Realmente, o processo decisório do magistrado é complexo. A relação magistrado-norma, na interpretação jurídica, não é meramente contemplativa, como uma verdade revelada, mas sim uma atividade subjetiva, na qual o juiz intérprete apresenta um papel ativo e, na execução desse papel, ganha relevância a emoção e a personalidade do juiz, sobre a qual influem a educação geral, a educação jurídica, os valores, os vínculos familiares e pessoais, a posição econômica e social, a experiência política e jurídica, a opinião política, os traços intelectuais e temperamentais ${ }^{145}$ e a cultura na qual se encontra inserido, mas isso não quer dizer que ele não possa decidir com base em um raciocínio lógico.

Realmente, o processo hermenêutico envolve não apenas o momento da compreensão e da interpretação, mas também o da aplicação, e, em todos eles, é preciso racicínio. A definição clássica de raciocínio é dada por Aristóteles. O raciocínio é um argumento em que, estabelecidas certas coisas, outras coisas diferentes se deduzem necessariamente das primeiras. O raciocínio é uma demonstração quando as premissas das quais parte são verdadeiras e primeiras, ou quando o conhecimento que delas temos provém originariamente de premissas primeiras e verdadeiras: e, por outro lado, o raciocínio é dialético quando parte de opiniões geralmente aceitas. São verdadeiras e primeiras aquelas coisas nas quais acreditamos em virtude de nenhuma outra coisa que não seja elas próprias; pois, no tocante aos primeiros princípios da ciência, é descabido buscar mais além o porquê e as razões dos mesmos; cada um dos primeiros princípios deve impor a convicção da sua verdade um si mesmo e por si mesmo. São, por outro lado, opiniões

\footnotetext{
${ }^{143}$ MACCORMICK, Neil. Legal reasoning and legal theory. Oxford: Claredon Press, 1997. p. 35-36.

${ }^{144}$ GADAMER, Hans-Georg. Gadamer in conversation: reflections and commentary, cit., p. 10.

${ }^{145}$ PRADO, Lídia Reis de Almeida. O juiz e a emoção: aspectos da lógica da decisão judicial. Campinas: Millenium, 2003. p. 14-15.
} 
geralmente aceitas aquelas que todo mundo admite, ou a maioria das pessoas, ou os filósofos - em outras palavras: todos, a maioria ou os mais notáveis e eminentes. ${ }^{146}$

A importância da aplicação do silogismo ao Direito surge apenas com a modernidade e o sucesso do positivismo científico, havendo sido o seu uso defendido pelos iluministas do século XVIII, em face da preocupação com a justa e segura aplicação das normas $^{147}$. Na atualidade, apresenta-se necessário não só em face da preservação do valor segurança, como também de outros já positivados na Constituição Federal.

Se o silogismo não é a forma natural do nosso raciocinar e não compreende toda complexidade do processo decisório, não deve ser desprezado por isso, porque ainda é um modo seguro de evitar erros. Se o magistrado raciocinar silogisticamente, facilmente verificará seus erros e suas virtudes. Raciocinar dessa maneira exige paciência, devoção, esmero e disciplina.

É inegável que, no proceder do raciocínio, surgem inúmeras ocasiões em que o pensamento não só vacila como claudica, a ponto de erros se apresentarem como verdades definitivas. $O$ aspecto subjetivo da evidência, que se firma na convicção, na adesão firme de nosso espírito sem vacilação, termina, em face do suceder dos fatos ou do próprio raciocínio, revelando que aquela verdade ocultava um grande erro. Dessa forma, embora o silogismo não compreenda toda a complexidade do processo decisório, é um bom instrumento para ser utilizado como método de raciocínio. ${ }^{148}$

O silogismo é um raciocínio lógico. A Lógica é uma reunião coordenada das regras e normas alcançadas, justificadas pela experiência. Os estudos de lógica promovidos por Aristóteles tiveram grande poder de influência durante toda a Idade Média, cujo maior expoente é a Escolástica de Tomás de Aquino, que elegeu o direito como um dos objetos mais importantes de suas reflexões. A doutrina aristotélica dos silogismos foi, durante quase dois mil anos, a única fonte informadora da lógica formal. Tudo isso a justificar e valorizar o imenso trabalho que tiveram os grandes filósofos, através dos séculos, para encontrar regras seguras que permitissem um raciocínio isento, tanto quanto possível, de erros. $^{149}$

\footnotetext{
${ }^{146}$ ARISTÓTELES. Tópicos. São Paulo: Abril Cultural, 1978. Livro 1, p. 5. (Os pensadores).

${ }^{147}$ PARINI, Pedro. op. cit.

${ }^{148}$ SANTOS, Mario Ferreira dos. op. cit.

${ }^{149}$ Id. Ibid.
} 
Bertrand Russell, lógico moderno, considera todas as teorias lógicas de Aristóteles falsas, sendo a única exceção a teoria dos silogismos. Para ele, o que poderia parecer um indício de consistência da lógica aristotélica diante de seu sucesso por quase dois mil anos, é uma prova de que o momento em que surgem essas teorias era o declínio da criatividade grega e, consequentemente, uma vitória do argumento de autoridade durante a Idade Média, o que traduziria um período de estagnação no desenvolvimento da lógica. $^{150}$

Ao princípio fundamental do silogismo, princípio da não contradição, também poderia ser oposto o argumento de física quântica conhecido como o gato de Schrödinger, segundo o qual uma entidade poderia ser e não ser ao mesmo tempo. Trata-se de um experimento mental, frequentemente descrito como um paradoxo, desenvolvido pelo físico austríaco Erwin Schröndinger, ilustrado na figura de um gato que poderia estar vivo ou morto ao mesmo tempo, dependendo de um evento aleatório precedente. Todavia, esse experimento só se verifica no mundo quântico e não no mundo quotidiano, macroscópico ${ }^{151}$, onde o Direito se aplica.

Realmente, o silogismo é um raciocínio dedutivo, no qual se comparam dois extremos com um terceiro. Pode em parte ser reduzido ao axioma de que "duas coisas idênticas a uma terceira são idênticas entre si”. Funda-se no princípio da não contradição: “é impossível que uma coisa seja e não seja ao mesmo tempo".

Aristóteles definia-o como "o enunciado no qual, tendo-se proposto algumas coisas, decorre delas, necessariamente, outra coisa, pelo só fato de serem dadas". O

\footnotetext{
${ }^{150}$ RUSSELL, Bertrand. History of western philosophy. London: Routledge, 1996. p. 188-194.

${ }^{151} \mathrm{O}$ Gato de Schrödinger é um experimento mental, freqüentemente descrito como um paradoxo, desenvolvido pelo físico austríaco Erwin Schrödinger em 1935. Isso ilustra o que ele observou como o problema da interpretação de Copenhague da mecânica quântica sendo aplicado a objetos do dia-a-dia, no exemplo de um gato que pode estar vivo ou morto, dependendo de um evento aleatório precedente. $\mathrm{O}$ gato de Schrödinger foi pensado como exemplo para mostrar claramente as diferenças existentes entre o mundo quotidiano e o mundo quântico. O gato que dá o título é um animal inventado por Schrödinger que escreveu: Qualquer um pode mesmo montar casos bem ridículos. Um gato é preso em uma câmara de aço, enquanto com o dispositivo seguinte (o qual deve estar seguro contra interferência direta do gato): em um contador Geiger tem uma pequena quantidade de substância radioativa, tão pequena, que talvez durante o período de uma hora, um dos átomos decaia, mas também, com a mesma probabilidade, talvez nenhum; se isso acontecer, o tubo do contador descarrega e através de um relé libera um martelo que quebra um pequeno frasco de Cianeto hídrico. Se algum deles tiver saído do seu sistema natural por uma hora, alguém pode concluir que o gato permanece vivo enquanto o átomo não tiver decaído. A função-psi do sistema poderia ser expresso por ter dentro dele o gato morto-vivo (com o perdão da palavra) misturada ou dividido em partes iguais. É típico desses casos que uma indeterminação originalmente restrita ao domínio atômico tenha sido transformada em uma indeterminação macroscópica, o qual pode então ser resolvido por observação direta. Isso nos previne de aceitar tão inocentemente como válido um "modelo confuso" para representar a realidade. Por si mesmo, ele não explicaria qualquer coisa imprecisa ou contraditória:existe uma diferença entre uma fotografia tremida ou desfocada e uma foto de nuvens e neblina.
} 
silogismo não diz nada mais do que já foi dito, do que está contido numa das premissas. O silogismo é um raciocínio que vai do geral ao particular; portanto, o que está contido na conclusão já está na premissa. Não oferece nenhum valor inventivo, mas apenas expositivo.

No raciocínio silogístico, se as premissas são verdadeiras, então o será a conclusão, mas a lógica por si não pode estabelecer ou garantir a verdade das premissas a serem escolhidas pelo magistrado. Como dizia Kant, não há regras para se aprender a aplicar as regras corretamente. ${ }^{152}$

O silogismo é um bom instrumento para o juiz utilizar em seu ofício, porque o Direito não é uma entidade pré-fabricada e precisa de ser construído passo a passo pelo julgador, a quem cabe encontrar, em relação ao caso concreto, uma combinação ordenada entre fatores diversos.

Embora o direito a aplicar, nos casos de indeterminação, forme uma moldura dentro da qual existem várias possibilidades de escolha ${ }^{153}$, o que observamos, no caso analisado, não foi a formação de várias possibilidades de interpretação do direito posto, mas sim um equívoco de qual seria a premissa maior possível.

O ponto de partida ou a premissa maior do raciocínio a ser desenvolvido pelo magistrado é dogmático, e sua ordem decorre de nosso sistema escalonado de normas jurídicas, com início nos princípios constitucionais gerais, passando pelos princípios específicos, terminando nas normas infraconstitucionais.

Como se vê, o magistrado se esqueceu de que a premissa maior de seu raciocínio é o ordenamento jurídico, encontrando-se a o princípio constitucional (no caso, a presunção de inocência) na camada jurídico-positiva mais alta. Pelo contrário, partiu seu raciocínio da premissa de que "Num momento em que toda sociedade clama por paz e justiça, o que menos se precisa é que casos como o que ora se estuda ocorram, por isso uma resposta rígida e imediata do judiciário é necessária”

A moldura dentro da qual poderia formatar a sua decisão já se encontra delineada na Constituição Federal, que positiva princípios de aplicação obrigatória para o

\footnotetext{
${ }^{152}$ GADAMER, Hans-Georg. Gadamer in conversation: reflections and commentary, cit., p. 42.

${ }^{153}$ Nesse sentido, KELSEN, Hans. op. cit., p. 297: "Em todos os casos de indeterminação oferecem-se várias possibilidades de aplicação jurídica. O Direito a aplicar forma, então, uma moldura dentro da qual existem várias possibilidades de aplicação, sendo conforme ao Direito todo ato que se mantenha dentro desse quadro ou moldura, que preencha essa moldura em qualquer sentido possível".
} 
juiz, impondo a interpretação restritiva das leis que limitam o livre exercício da liberdade dos cidadãos. Nesse sentido, quanto mais intensa se revelar a intervenção em um dado direito fundamental, maiores hão de se revelar os fundamentos justificadores dessa intervenção. $^{154}$

Logo, verificamos que a forma desorganizada do raciocínio desenvolvido pelo magistrado e confirmado pelo Tribunal de Justiça do Pará, afetou a decisão do caso concreto.

Haverá quem diga que o ato de interpretação não é somente ato de razão, mas também ato de vontade e que a interpretação jurídico-científica, como advertia Kelsen ${ }^{155}$ "tem de evitar, com o máximo cuidado, a ficção de que uma norma jurídica apenas permite, sempre e em todos os casos, uma só interpretação: a interpretação "correta".

Contra ela, no caso concreto, milita a clareza dos enunciados dos princípios constitucionais de bloqueio já mencionados. E não é tudo, porque admitir a alternativa de uma multiplicidade infinita de leituras dos princípios constitucionais seria transformar os aplicadores da lei em árbitros da alteração contínua da legalidade no país.

"[...] e melhor seria abolir de uma vez, totalmente, com tôdas as leis ordinárias ou constitucionais; porque se teria diante dos olhos a responsabilidade nua de uma situação de arbítrio formal e ilimitadamente consagrada... Porque é pelas palavras que o homem se exprime, que o homem contrata, é pelas palavras que o homem empenha a sua fé, que o homem assume os seus compromissos e que os obriga [...] Se nos fosse lícito alterar o sentido às palavras, necessidade nenhuma haveria de reformar as leis. Poderíamos conservá-las perpetuamente, dando-lhes sucessivamente, de dia em dia, a inteligência que o interêsse da ocasião aconselhasse."156

Nesse mesmo sentido, Umberto Eco ${ }^{157}$ demonstra a necessidade de um padrão para interpretação aceitável, sublinhando a "importância da intenção da obra, que, não obstante inconfundível com a intenção do autor, e, portanto, incapaz de subordinar o leitor às motivações subjetivas que atuaram no processo de elaboração do texto, fixa um universo de interpretações possíveis ao leitor modelo. E. Rui Barbosa, por sua vez, adverte não ser opinativa a matéria de interpretação quando ao sentido vernáculo de uma palavra,

\footnotetext{
${ }^{154}$ ALEXY, Robert. Palestra proferida na Fundação Casa de Rui Barbosa. Rio de Janeiro, 10.12.98.

${ }^{155}$ KELSEN, Hans. op. cit., p. 297.

${ }^{156}$ BARBOSA, Rui. Tribuna Parlamentar. Casa Rui Barbosa, 1956. v. 5.

${ }^{157}$ Formulações de Umberto Eco, apresentadas na Conferência Tanner de Cambridge, 1990.
} 
quanto à acepção das palavras cujo sentido se acha firmado pelo uso universal dos escritores, pela explicação dos lexicógrafos, pelo conhecimento universal de todos os que falam uma língua. As palavras têm sentido certo, determinado pela sua história, pelo uso de aplicá-las, pelo consenso daqueles que as empregam; as palavras são a garantia da estabilidade das línguas. Só um poder existe que é dado alterar-lhe o sentido, esse poder é o uso. "A êsse, a competência, autoridade, a soberania, a onipotência de alterar o sentido das palavras; mas essa alteração não se traduz senão lentamente, gradativamente, paulatinamente, em uma sucessão de anos, de tempos, às vezes de séculos consecutivos”.

Nesse sentido também a famosa observação de Wittgenstein de que não há língua privativa. Qualquer um que fale uma língua que ninguém mais fale, não está realmente falando. Linguagem não é alguma coisa designada por um sujeito individualmente. Linguagem é um nós, no sentido de designarmos o nosso lugar na relação um a outro e na qual o individual não apresenta fronteiras. Isso significa que todos precisamos ultrapassar nossos limites de compreensão para compreender. Esse nós é o que acontece na maneira com que trocamos conversas. Conviver em uma comunidade é conviver junto em uma mesma linguagem, e a linguagem existe somente no diálogo. ${ }^{158}$

As idéias do magistrado ficariam mais organizadas, juridicamente falando, se ele desenvolvesse um raciocínio silogístico, no qual os princípios constitucionais, valores consensualmente aceitos pela sociedade e internos ao ordenamento jurídico, assumam a posição de premissa maior.

O que verificamos, na análise desse caso, não foi um equívoco de interpretação da norma, mas na identificação do princípio condutor do raciocínio e seria uma contramarcha aos crepusculares tempos de negação dos direitos humanos a discricionariedade na aplicação ou não dos princípios constitucionais. Em lugar da segurança do consenso que eles representam, teríamos “os erros de apreciação, os ódios pessoais ou partidários, os caprichos da prepotência, o ímpeto das paixões de momento, as

\footnotetext{
${ }^{158}$ GADAMER, Hans-Georg. Gadamer in conversation: reflections and commentary, cit., p. 56: "There is no private language. Whoever speaks a language that nobody else understands is not really speaking. Language is not something assigned by individual human subjects. Language is a we, in that we are assigned our place in relation to each other, and in which the individual has no fixed borders. This means, however, that we all must overstep our own personal borders/limits of understanding in order to understand. This is what happens in the living exchange of conversation. All living together in a community is living together in language, and language only exists in conversation.
} 
sentenças inspiradas na covardia ou servilismo em face dos governantes ou, o que é pior, em face da opinião pública" ${ }^{159}$.

\subsection{O Caso Ellwanger (HC 82.424/RS)}

\subsubsection{Análise do caso}

O caso pode ser assim resumido: Siegfried Ellwanger, editor de livros em Porto Alegre, foi absolvido em primeiro grau de jurisdição, mas condenado pela $3^{\text {a }}$ Câmara Criminal do Tribunal de Justiça do Rio Grande do Sul, a dois anos de reclusão, com sursis pelo prazo de quatro anos, como incurso no caput do artigo 20 da Lei 7.716/89, na redação dada pela Lei 8081/90,(Art. 20. Praticar, induzir ou incitar a discriminação ou preconceito de raça, cor, etnia, religião ou procedência nacional. Pena: reclusão de um a três anos e multa.).

O réu, na qualidade de escritor e sócio da empresa "Revisão Editora Ltda.", editou, distribuiu e vendeu ao público obras antissemitas de sua autoria intituladas "Holocausto- Judeu ou Alemão? Nos bastidores da mentira do século" e da autoria de autores nacionais e estrangeiros ("O Judeu Internacional”, de Henry Ford; "A História Secreta do Brasil", "Brasil - Colônia de Banqueiros", "Os Protocolos dos Sábios de Sião"; "Hitler - Culpado ou Inocente?"; “Os Conquistadores do Mundo - os verdadeiros criminosos e guerra"), que abordam e sustentam mensagens anti-semitas, racistas $e$ discriminatórias," procurando com isso, segundo a denúncia, incitar e induzir a discriminação racial, semeando em seus leitores sentimentos de ódio, desprezo e preconceito contra o povo de origem judaica, havendo o desembargador José Eugênio Tedesco ressaltado no seu voto a "supremacia valorativa do dever de não discriminar" consagrado na Constituição de 1988.

Em novembro de 2000, foi impetrado no Superior Tribunal de Justiça (STJ) habeas corpus em seu favor e denegado em dezembro de 2001 pela decisão majoritária da 5 . Turma. $\mathrm{O}$ argumento central do $\mathrm{HC}$ reside no fato de o crime praticado por Ellwanger ser de incitamento contra os judeus, mas não o da prática de racismo, porque os judeus não são uma raça. Afastada a prática do crime de racismo, o delito estaria prescrito.

\footnotetext{
${ }^{159}$ HUNGRIA, Nelson. op. cit., v. 1, t. 1, p. 23.
} 
No STJ, o relator Ministro Gilson Dipp, denegou a ordem porque $a$ condenação do paciente se deu por delito contra a comunidade judaica, não se podendo abstrair o racismo de tal comportamento.

Novo pedido de HC foi impetrado perante o STF, sob a mesma argumentação, e foi indeferido por maioria, segundo os votos dos Ministros Maurício Corrêa, Sepúlveda Pertence, Celso de Mello, Carlos Velloso, Nelson Jobim, Ellen Gracie, Gilmar Mendes e Ceszar Peluso. Foram votos vencidos os ministros Moreira Alves e Marco Aurélio que concederam a ordem para acolher a prescrição da pretensão punitiva do Estado e ministro Carlos Britto que concedeu a ordem ex officio para absolver o paciente por falta de tipicidade de conduta.

"Habeas corpus. Publicação de livros: anti-semitismo. Racismo. Crime imprescritível. Conceituação. Abrangência constitucional. Liberdade de Expressão. Limites. Ordem denegada.

Escrever, editar, divulgar e comerciar livros "fazendo apologia de idéias preconceituosas e discriminatórias"contra a comunidade judaica (Lei 7.716/89, artigo 20, na redação dada pela Lei 8.081/90) constitui crime de racismo sujeito às cláusulas de inafiançabilidade e imprescritibilidade (CF, artigo $5^{\circ}$, XLII).

Aplicação do princípio da prescritibilidade geral dos crimes: se os judeus não são uma raça, segue-se que contra eles não pode haver discriminação capaz de ensejar a exceção constitucional de imprescritibilidade. Inconsistência da premissa.

Raça humana. Subdivisão. Inexistência. Com a definição e o mapeamento do genoma humano, cientificamente não existem distinções entre os homens, seja pela segmentação da pele, formato dos olhos, altura, pêlos ou por quaisquer outras características físicas, visto que todos se qualificam como espécie humana. Não há diferenças biológicas entre os seres humanos. Na essência são todos iguais.

Raça e racismo. A divisão dos seres humanos em raças resulta de um processo de conteúdo meramente político-social. Desse pressuposto origina-se o racismo que, por sua vez, gera a discriminação e o preconceito segregacionista.

Fundamento do núcleo do pensamento do nacional-socialismo de que os judeus e os arianos formam raças distintas. Os primeiros seriam raça inferior, nefasta e infecta, características suficientes para justificar a segregação e o extermínio: inconciabilidade com os padrões éticos e morais definidos na Carta Política do Brasil e do mundo contemporâneo, sob os quais se ergue e se harmoniza o estado democrático. Estigmas que por si sós evidenciam crime de racismo. Concepção atentatória dos princípios nos quais se origina e se organiza a sociedade humana, baseada na respeitabilidade e dignidade do ser humano e de sua pacífica convivência no meio social. Condutas e evocações aéticas e imorais que implicam em repulsiva ação estatal por se revestirem de densa intolerabilidade, de sorte a afrontar o ordenamento infraconstitucional e constitucional do País. 
Adesão do Brasil a tratados e acordos multilaterais, que energeticamente repudiam quaisquer discriminações raciais, aí compreendidas as distinções entre os homens por restrições ou preferências oriundas de raça, cor, credo, descendência ou origem nacional ou étnica, inspiradas na pretensa superioridade de um povo sobre o outro, de que são exemplos a xenofobia, "negrofobia", "islamafobia" e o anti-semitismo.

A Constituição de 1988 impôs as agentes de delito dessa natureza, pela gravidade e repulsividade da ofensa, a cláusula de imprescritibilidade, para que fique, ad perpetuam rei memoriam, verberando o repúdio e abjeção da sociedade nacional à sua prática.

Racismo. Abrangência. Compatibilização dos conceitos etimológicos, etnológicos, sociológicos, antropológicos ou biológicos, de modo a construir a definição jurídico-constitucional do termo. Interpretação teleológica e sistêmica da Constituição Federal, conjugando fatores e circunstâncias históricas, políticas e sociais que regeram a sua formação e aplicação, a fim de obter o real sentido e alcance da norma.

Direito comparado. A exemplo do Brasil as legislações de países organizados sob a égide do estado moderno de direito democrático igualmente adotam em seu ordenamento legal punições para delitos que estimulem e propaguem segregação racial. Manifestações da Suprema Corte norte- americana, da Câmara dos Lordes da Inglaterra e da Corte de Apelação da Califórnia nos Estados Unidos que consagram entendimento que aplicam, igualmente, sanções àqueles que transgridem as regras de boa convivência social com grupos humanos que simbolizam o exercício do racismo.

A edição e publicação de obras escritas veiculando idéias anti-semitas, que buscam resgatar e dar credibilidade à concepção racial definida pelo regime nazista, negadoras e subversoras de fatos históricos incontroversos como o holocausto, consubstanciadas na pretensa inferioridade e desqualificação do povo judeu, equivalem à incitação ao discrímen com acentuado conteúdo racista, reforçadas pelas conseqüências históricas dos atos em que se baseiam.

Explícita conduta do agente responsável pelo agravo revelador de manifesto dolo, baseada na equivocada premissa de que os judeus não só são uma raça, mas, mais do que isso, um segmento racial atávica e geneticamente menor e pernicioso.

Discriminação que no caso se evidencia como deliberada e dirigida especificamente aos judeus, que configura ato ilícito de prática de racismo, com as consequiências gravosas que o acompanham.

Liberdade de expressão. Garantia constitucional que não se tem como absoluta. Limites morais e jurídicos. $\mathrm{O}$ direito à livre expressão não pode abrigar em sua abrangência, manifestações de conteúdo imoral que implicam ilicitude penal.

As liberdades públicas não são incondicionais, por isso devem ser exercidas de maneira harmônica, observados os limites definidos na própria Constituição Federal (CF, artigo $5^{\circ}$, parágrafo $2^{\circ}$, primeira parte). $\mathrm{O}$ preceito fundamental de liberdade de expressão não consagra o "direito à incitação ao racismo", dado que um direito individual não pode constituir-se em salvaguarda de condutas ilícitas, como sucede com os delitos contra a honra. Prevalência dos princípios da dignidade da pessoa humana e da igualdade jurídica. 


\begin{abstract}
"Existe um nexo estreito entre a imprescritibilidade, este tempo jurídico que se escoa sem encontrar termo, e a memória, apelo do passado à disposição dos vivos, triunfo da lembrança sobre o esquecimento". No estado de direito democrático devem ser intransigentemente respeitados os princípios que garantem a prevalência dos direitos humanos. Jamais podem se apagar da memória dos povos que se pretendam justos os atos repulsivos do passado que permitiram e incentivaram o ódio entre os iguais por motivos raciais de torpeza inominável.
\end{abstract}

A ausência de prescrição nos crimes de racismo justifica-se como alerta grave para as gerações de hoje e de amanhã, para que se impeça a reinstauração de velhos e ultrapassados conceitos que a consciência jurídica e histórica não mais admitem.

Ordem denegada."

A questão central discutida no acórdão girou em torno do termo "racismo" empregado pelo constituinte no art. $5^{\circ}$, inciso XLII, para considerar ou não a conduta antissemita atribuída ao paciente. ("XLII - a prática do racismo constitui crime inafiançável e imprescritível, sujeito à pena de reclusão, nos termos da lei”)

Nesse julgamento, marco na jurisprudência brasileira de direitos humanos $^{160}$, todos os Ministros do Supremo Tribunal Federal proferiam votos circunstanciados, debatendo a questão concernente à abrangência do crime de racismo e hipóteses de conflito de princípios constitucionais. Analisaram o elemento histórico e a gênese da previsão contida no artigo $5^{\circ}$, XLII, da Carta da República, bem como o alcance do termo racismo empregado pelo constituinte.

Os Ministros do Supremo Tribunal Federal enfrentam com profundidade a questão polêmica, analisando e ponderando vários princípios constitucionais, dentre eles, os princípios da dignidade da pessoa humana, da liberdade de expressão e de opinião numa sociedade democrática e o direito à não discriminação.

Observemos que o raciocínio utilizado pelos magistrados seguiu uma determinada ordem, começando pela análise dos princípios constitucionais em discussão. A escolha da prevalência de um princípio sobre o outro apareceu em um momento posterior do desenvolvimento do raciocínio, quando surgiram hipóteses reais de indeterminação: a extensão da palavra racismo e o princípio orientador preponderante: dignidade da pessoa humana X liberdade de expressão.

\footnotetext{
${ }^{160}$ LAFER, Celso. A internacionalização dos direitos humanos: constituição, racismo e relações internacionais, cit.
} 
Analisemos melhor a questão.

O Ministro Moreira Alves, relator do acórdão, concluiu que, não sendo os judeus uma raça, não se poderia qualificar o crime por discriminação pelo qual foi condenado o paciente como delito de racismo, tornando assim imprescritível a pretensão punitiva do Estado. Os Ministros que negaram a ordem de habeas corpus acolheram os argumentos apresentados pelo Professor Celso Lafer, da Faculdade Direito da Universidade de São Paulo, em parecer oferecido na condição de amicus curiae, que analisou a questão acerca do conceito de racismo empregado na Constituição, nos seguintes termos:

"O conteúdo jurídico do preceito constitucional consagrado pelo art. $5^{\circ}$, XLII, do crime da prática de racismo, tipificado pela legislação infraconstitucional, reside nas teorias e preconceitos que estabelecem diferenças entre grupos e pessoas, a eles atribuindo as características de uma raça para discriminá-las. Daí a repressão prevista no art. 20 da Lei 7.716/89, com a redação dada pela Lei 8.081/90. Só existe uma raça - a espécie humana - e, portanto, do ponto de vista biológico, não apenas os judeus, como também os negros, os índios, os ciganos ou quaisquer outros grupos, religiões ou nacionalidades não formam raças distintas. É o que diz a Declaração da Unesco de 1978 sobre Raça e Racismo; é o que dizem autores citados pelo impetrante, que mostram que raça é uma construção histórico-social, voltada para justificar a desigualdade. Esta omissão é o ponto de partida da falaciosa argumentação do impetrante. Com efeito, os judeus não são uma raça, mas também não são raça os negros, os mulatos, os índios e quaisquer outros integrantes da espécie humana que, no entanto, podem ser vítima da prática de racismo. É o caso, por exemplo, dos parias na Índia, discutido na Conferência de Durban sobre Racismo, vítimas de um preconceito de origem e não de marca, para recorrer à distinção de Oracy Nogueira. Interpretar o crime da prática do racismo a partir do conceito de "raça", como argumenta o impetrante, exprime não só uma seletividade que se coloca em questão a universalidade, interdependência e inter-relacionamento, que compõem a indivisibilidade dos direitos humanos, afirmada, em nome do Brasil, pelo Ministro Maurício Corrêa em Viena.Representa, sobretudo, reduzir o bem jurídico tutelado pelo Direito brasileiro, o que não é aceitável como critério de interpretação dos direitos e garantias constitucionais. No limite, esta linha de interpretação restritiva pode levar à inação jurídica por força do argumento contrario sensu, que cabe em matériap enal. Com efeito, levadas às últimas consequiências, ela converteria a prática do racismo, por maior que fosse o esmero da descrição da conduta, em crime impossível pela inexistência do objeto: as raças (...).”.

Entenderam os senhores Ministros que o sentido emblemático da discussão consistia na definição do princípio da dignidade da pessoa humana, que confere legitimação ético-jurídica à ordem normativa sobre a qual se edifica e se estrutura o Estado 
Democrático de Direito. Esse princípio representa o reconhecimento de que reside, na pessoa humana, o valor fundante do Estado e da ordem que lhe dá suporte institucional, valor este representativo de um consenso universal sedimentado na Declaração Universal dos Direitos da Pessoa Humana e na Declaração de Viena.

As diversas proclamações constantes da Declaração de Viena enfatizam o compromisso de todos os Estados de promoverem o respeito universal e a observância e proteção de todos os direitos humanos e liberdades fundamentais das pessoas, razão pela qual os juízes devem extrair das declarações internacionais e das proclamações constitucionais a sua máxima eficácia, sob pena de a liberdade, a tolerância e o respeito à alteridade humana tornarem-se palavras vãs.

Colocada a questão da afirmação e definição do conceito da dignidade da pessoa humana, passaram os Ministros a analisar se a incitação ao ódio público contra o povo judeu estaria protegida pela cláusula constitucional que assegura a liberdade de expressão.

Resumidamente, foram esses os argumentos utilizados pelos Ministros que negaram a ordem de habeas corpus:

O exercício concreto da liberdade de expressão pode gerar

"situações de tensão dialética entre valores essenciais, igualmente protegidos pelo ordenamento constitucional, dando causa a verdadeiro estado de colisão de direitos, caracterizado pelo confronto de liberdades revestidas de idêntica estatura jurídica, a reclamar solução que, tal seja o contexto em que se delineie, torne possível conferir primazia a uma das prerrogativas básicas, em relação de antagonismo com determinado interesse fundado em cláusula inscrita na própria Constituição."161

"A liberdade de informação deve ser exercida de modo compatível com o direito à imagem, à honra e à vida privada. Não se pode atribuir primazia absoluta à liberdade de expressão, no contexto de uma sociedade pluralista, em face de valores outros como os da igualdade e da dignidade da pessoa humana. Daí ter o texto constitucional de 1988 erigido, de forma clara e inequívoca, o racismo como crime inafiançável e imprescritível (CF, ar. $5^{\circ}$, XLII), além de ter determinado que a lei estabelecesse outras formas de repressão às manifestações discriminatórias (art. $\left.5^{\circ}, \mathrm{XLI}\right) .{ }^{162}$

“(...) A liberdade de expressão, incluindo a liberdade de imprensa, é fundamental para a democracia. Se a democracia é definida como controle popular do governo, então, se o povo não puder expressar seu ponto de vista livremente, esse controle não é possível. Não seria uma sociedade democrática. Mas, igualmente, o elemento central da

\footnotetext{
${ }^{161}$ Voto proferido pelo Ministro Celso de Mello.
}

${ }^{162}$ Voto proferido pelo Ministro Gilmar Mendes. 
democracia é o valor da igualdade política. 'Every one counts as one no more than one', como diz Jeremy Bentham. Igualdade política é, consequentemente, também necessária se uma sociedade pretende ser democrática. Uma sociedade que objetiva a democracia deve tanto proteger o direito de liberdade de expressão quanto o direito à não discriminação. Para atingir a igualdade política é preciso proibir a discriminação ou a exclusão de qualquer sorte, que negue a alguns o exercício de direitos, incluindo o direito à participação política. Para atingir a liberdade de expressão é preciso evitar a censura governamental aos discursos e à imprensa (...)", 163

Estabelecido o conflito entre dois princípios constitucionais, a solução encontrada foi a utilização do princípio da proporcionalidade, fundamentada na lição de Robert Alexy: "O postulado da proporcionalidade em sentido estrito pode ser formulado [assim]: 'quanto mais intensa se revelar a intervenção em dado direito fundamental, maiores hão de se revelar os fundamentos justificadores dessa intervenção'."164

Extraímos do voto do Ministro Gilmar Mendes que a aplicação do princípio da proporcionalidade se dá quando verificada restrição a determinado direito fundamental ou um conflito entre distintos princípios constitucionais de modo a se exigir que se estabeleça o peso relativo de cada um dos direitos por meio da aplicação das máximas que integram o princípio da proporcionalidade.

São três as máximas parciais do princípio da proporcionalidade: a adequação, a necessidade e a proporcionalidade em sentido estrito. Na aplicação desse princípio há de perquirir-se se, em face do conflito entre dois bens constitucionais contrapostos, o ato impugnado afigura-se adequado (isto é, apto para produzir o resultado desejado), necessário (isto é, insubstituível por outro meio menos gravoso e igualmente eficaz) e proporcional em sentido estrito (ou seja, se estabelece uma relação ponderada entre o grau de restrição de um princípio e o grau de realização do princípio contraposto).

O princípio da proporcionalidade, na lição de Canotilho, aplica-se a todas as espécies de atos dos poderes públicos, de modo que vincula ao legislador, à administração e ao judiciário. ${ }^{165}$

É adequada, afirma o Ministro Gilmar Mendes,

"a condenação do paciente para se alcançar o fim almejado, qual seja, a salvaguarda de uma sociedade pluralista, onde se reine a tolerância.

\footnotetext{
${ }^{163}$ Referência feita pelo Ministro Gilmar Mendes a Kevin Boyle, Hate Speech, p. 40.

${ }^{164}$ ALEXY, Robert. Palestra proferida na Fundação Casa de Rui Barbosa, cit.

${ }^{165}$ CANOTILHO, Joaquim José Gomes. op. cit.
} 
Assegura-se a posição do Estado, no sentido de defender os fundamentos da dignidade da pessoa humana (art. $1^{\circ}$,III, CF), do pluralismo político (art. $1^{\circ}, \mathrm{V}, \mathrm{CF}$ ), o princípio do repúdio ao terrorismo e ao racismo, que rege o Brasil nas suas relações internacionais (art. $4^{\circ}$, VIII), e a norma constitucional que estabelece ser o racismo um crime imprescritível (art $\left.5^{\circ}, \mathrm{XLII}\right)$.

Também não há dúvida de que a decisão condenatória, tal como proferida, seja necessária, sob o pressuposto de ausência de outro meio menos gravoso e igualmente eficaz. Com efeito, em casos como esse, dificilmente vai se encontrar um meio menos gravoso a partir da própria definição constitucional. Foi o próprio constituinte que determinou a criminalização e a imprescritibilidade da prática do racismo. Não há exorbitância no acórdão.

Tal como anotado nos doutos votos não se trata sequer de obras revisionistas da história, mas de divulgação de idéias que atentam contra a dignidade dos judeus. Fica evidente, igualmente, que se não cuida, nos escritos em discussão, de simples discriminação, mas de textos que, de maneira reiterada, estimulam o ódio e a violência contra os judeus. Ainda assim, o próprio Tribunal de Justiça do Estado do Rio Grande do Sul agiu com cautela na dosagem da pena, razão pela qual também aqui a decisão atende ao princípio da 'proibição do excesso'.

A decisão atende, por fim, ao requisito da proporcionalidade em sentido estrito. Nesse plano, é necessário aferir a existência de proporção entre o objetivo perseguido, qual seja, a preservação dos valores inerentes a uma sociedade pluralista, da dignidade humana, e o ônus imposto à liberdade de expressão do paciente. Não se contesta, por certo, a proteção conferida pelo constituinte à liberdade de expressão. Não se pode negar, outrossim, o seu significado inexcedível para o sistema democrático. Todavia, é inegável que essa liberdade não alcança intolerância racial e o estímulo à violência, tal como afirmado no acórdão condenatório. Há inúmeros outros bens jurídicos de base constitucional que estariam sacrificados na hipótese de se dar uma amplitude absoluta, intangível, à liberdade de expressão na espécie"

\subsubsection{A correta assunção do princípio constitucional como premissa maior}

A exemplo do arrazoado constante do voto condutor do $\mathrm{HC} \mathrm{n}^{\circ} 56975-\mathrm{PA}$, relatado pela Ministra Maria Tereza, a maioria dos Ministros fixou, inicialmente, o princípio orientador do raciocínio e, passa a passo, foram prestigiando o princípio da dignidade da pessoa humana em detrimento do princípio da liberdade de expressão. Como explica Zagrebelsky ${ }^{166}$, a pluralidade de princípios e a ausência de uma hierarquia formal

\footnotetext{
${ }^{166}$ ZAGREBELSKY, op. cit., p. 110-111 e LAFER, Celso. A Constituição de 1988 e as relações internacionais: reflexões sobre o art. $4^{\circ}$. In: A internacionalização dos direitos humanos: constituição, racismo e relações internacionais, cit.
} 
entre eles faz com que não possa existir uma "ciência" sobre a sua articulação, mas apenas uma prudência na sua ponderação.

Como se vê, os critérios de interpretação foram fixados em função da escolha de um princípio constitucional ${ }^{167}$ : o princípio universal da dignidade da pessoa humana e da imprescritibilidade da prática do crime de racismo.

Com efeito, um dos pressupostos da hermenêutica do Direito é a inegabilidade do ponto de partida, havido como indiscutível. Nesse sentido, são dogmas hermenêuticos $^{168}$ o princípio da legalidade, segundo o qual as decisões devem ser fundamentadas nas leis do Estado, o princípio da justificação, segundo a qual os juízes devem justificar as próprias decisões e provar a sua não arbitrariedade, o princípio da inevitabilidade, segundo o qual os juízes têm obrigação de resolver todos os casos que se apresentem na sua esfera de competência. Tais princípios se acrescentam aos postulados da completude e coerência do ordenamento jurídico.

Sabemos que o ordenamento ${ }^{169}$ jurídico brasileiro constitui um sistema escalonado de normas jurídicas, situando-se a Constituição na camada jurídico-positiva mais alta, cuja função essencial consiste em regular os órgãos e o procedimento de produção jurídica geral da qual derivam e se relacionam direta ou indiretamente todas as demais normas do ordenamento.

Norberto Bobbio, um dos maiores pensadores da atualidade, pertencente a uma corrente jusfilosófica que se costuma denominar de "escola analítica" ou "positivismo analítico" apresenta uma definição de Direito. O termo Direito, na mais comum acepção do direito objetivo, indica um sistema normativo criado pelo homem. Logo, podemos dizer que o direito brasileiro abriga uma ordem de valores que se realizam por instrumentos normativos e a Constituição Federal é o lugar próprio desse reconhecimento.

\footnotetext{
${ }^{167}$ Nesse sentido, REALE, Miguel. Estudos de filosofia e ciência do direito. São Paulo: Saraiva, 1968. p. 134: "As tentativas de desvincular o Direito do princípio da legalidade e do seu caráter imperativo têm sido frustradas. Ademais, a imperatividade do direito, visto em termos histórico-axiológicos, não é um complexo de que devamos nos corrigir, mas uma das componentes relevantes do viver social, tão certo como o repúdio do poder é a inconsciência da liberdade".

${ }^{168}$ FARRALI, Carla. A filosofia contemporânea do direito: temas e desafios. Tradução Candice Premaor Gullo. São Paulo: Martins Fontes, 2006.

${ }^{169}$ Nesse sentido, LAFER, Celso. Direito e poder: apontamentos sobre o tema na reflexão de Miguel Reale. Revista da Faculdade de Direito da Universidade de São Paulo, v. 76, p. 203-221, 1981: "Na ótica do Direito, o Estado como instituição e organização, significa, em última instância, um conjunto de normas(ordenamento). Estas normas estabelecem competências que permitem o exercício do poder, inclusive o de criar e aplicar normas jurídicas."
} 
No Brasil o catálogo dos direitos humanos encontra-se expresso na Constituição Federal e nos princípios explícitos e implícitos por ela adotados, bem como em vários dos Tratados Internacionais ratificados pelo país, surgindo o princípio da dignidade humana como um valor perseguido pela sociedade em primeiro lugar.

Analisando os votos dos Ministros e a ementa do acórdão, concluímos haver o raciocínio seguido uma ordem de premissas e conclusões. Isso é importante, porque o raciocínio do juiz se desenvolve para a formação de uma conclusão acerca de determinada matéria e não apenas para o conhecimento da matéria em si mesma. E mais, qualquer que venha a ser sua decisão, deve ser fundamentada e justificada para que a sociedade possa exercer um controle sobre ela. Para tanto, a forma que o raciocínio silogístico pode ser usado como instrumento, não apenas para a escolha das premissas, mas também para a sua fundamentação e verificação de possíveis erros e inconsistências da conclusão.

Um argumento comum consiste em afirmar que a lógica, da qual o raciocínio silogístico é decorrente, é estéril, infecunda, não criativa. Isso seria o mesmo que a afirmar a esterilidade da matemática, que é especificamente lógica. Podemos dizer que a lógica não é criadora enquanto se resume à sua parte formal. Todavia, o exame dialético dos juízos é extremamente criativo em face dos inevitáveis desdobramentos dos juízos que estavam virtualizados e que vão aparecendo no curso de um processo dialético. É da lógica matemática que surgiram as Pirâmides de Gizé, os Jardins Suspensos da Babilônia, o Taj Mahal, as Muralhas da China. Enfim, a lógica é um instrumento e não um fim em si mesma.

\subsubsection{A busca dialética pela premissa menor (qualificação jurídica)}

Registramos, em função dessa observação, que o desafio maior, nesse caso, para a maioria dos Ministros, não foi achar a premissa maior, mas sim a premissa menor, qual seja, o fato e sua qualificação jurídica. Nesse ponto é interessante observar que a interpretação do Direito, com vistas à fixação do sentido da norma pelo magistrado, aparece em meio a um jogo dialético e público, oportunidade em que deve ser assegurado o lugar da controvérsia, da contestação, da defesa, da dissidência, a fim de que possa haver, em primeiro lugar, a compreensão. 
Muito bem. Considera-se como origem da palavra dialética, a palavra grega dialektikê, formada do prefixo dia e de logos, de onde dialogê, discussão, e o verbo dialegeyn, que significa terçar palavras ou razões, conversar, discutir. ${ }^{170}$

A dialética é a arte de esclarecer, descobrir a verdade através das idéias. E dizemos esclarecer, porque a alétheia, a verdade dos gregos, que não se confunde com o nosso conceito de verdade, significava iluminação, o clareamento, o iluminar que está em trevas. E como o espírito (nous) tem a razão (logos), era através desta (diá), que a luz poderia surgir, dissipando trevas.

A dialética coloca as partes em posições diferentes, em pontos opostos, trabalhando entre a luz e as trevas, entre opiniões boas e más, sopesando valores e opiniões, no correr de um diálogo, em que as partes enfretam opiniões diversas para, através delas, esclarecer. A Dialética é, assim, a arte de esclarecer por meio de idéias ${ }^{171}$.

No curso do processo judicial, obrigatoriamente dialético, ocorre uma rodada hermenêutica, para lembrar as palavras de Gadamer. E essa rodada dialética é a única forma de podermos chegar à compreensão da norma jurídica com vistas ao arbitramento de seu sentido, bem como à compreensão e fixação do fato e de sua qualificação jurídica. Como adverte Gadamer, a arte de interpretar envolve compreensão, que só pode ocorrer quando nos propomos não apenas a ouvir mas, realmente, a escutar um ao outro, porque texto é linguagem e linguagem é um "nós" e não um "eu" singular. ${ }^{172}$

Podemos dizer que o procedimento estabelecido no curso da relação processual equitativa é justamente a instituição da prudência: um tempo e um lugar para reflexão, para a fixação de um "nós”. Especialmente por esta razão, a Comissão e a Corte Européia de Direitos Humanos têm privilegiado, sistematicamente, entre todos os direitos fundamentais do Tratado dos quais têm custódia, o sexto, que se ocupa das garantias do processo equitativo, única forma de preservação de um jogo realmente dialético ${ }^{173}$, bem como a nossa Constituição positivou o princípio do devido processo legal, da paridade de armas, indispensável à concreta atuação do contraditório e à própria imparcialidade do juiz. ${ }^{174}$

\footnotetext{
${ }^{170}$ SANTOS, Mario Ferreira dos. op. cit., p. 27.

${ }^{171}$ Id. Ibid.

${ }^{172}$ GADAMER, Hans-Georg. Gadamer in conversation: reflections and commentary, cit., p. 39.

173 OST, François, op. cit.

${ }^{174}$ GRINOVER, Ada Pellegrini. O processo constitucional em marcha. 1. ed. São Paulo: Max Limonad, 1985. p. 15.
} 


\subsection{O silogismo no jogo dialético (HC No 34.987 - RJ)}

Trata-se de habeas corpus impetrado em favor de paciente que cumpre pena de seis anos e oito meses de reclusão, pelo cometimento do crime do art. $157, \S 2^{\circ}$, incisos I e II (duas vezes), combinado com o art. 70, ambos do Código Penal.

Após o cumprimento de um terço da pena, obteve o livramento condicional, deferido pelo Juízo da Vara de Execuções Criminais do Rio de Janeiro (RJ). Contra essa decisão, foi interposto Agravo em Execução pelo Ministério Público, o qual restou provido pelo Tribunal de Justiça por ser o agravado portador de maus antecedentes, apesar de primário tecnicamente.

Alegou a Defensoria Pública fluminense constrangimento ilegal, na medida em que teria havido interpretação in malam partem do disposto no inciso I do art. 83 do Código Penal, exigindo do portador de maus antecedentes o cumprimento do mesmo quantitativo de pena exigido para o condenado reincidente.

Acresceu haver, além da condenação em tela, cujo crime foi cometido em 3001/1989, apenas uma outra por prática de contravenção penal (art. 19 da Lei de Contravenção Penal), praticado em 19/08/2003, sancionado com pena de multa. Nesse contexto, ponderou haver a contravenção penal deixado de ser reconhecida pelo Juízo monocrático do processo de conhecimento, exatamente por haver sido praticada após o crime patrimonial. Não configurando antecedente, não pôde, na fase de execução, constituir-se em antecedente para efeito de elevar o cumprimento da pena para a obtenção do livramento.

Requereu a concessão de liminar a fim de que fosse suspenso o cumprimento do acórdão até a decisão definitiva do writ e, no mérito, o restabelecimento do livramento condicional anteriormente concedido.

Diz a ementa do acórdão:

HABEAS CORPUS. CRIME DE ROUBO QUALIFICADO. LIVRAMENTO CONDICIONAL DEFERIDO PELO JUÍZO SINGULAR. DECISÃO REFORMADA PELO TRIBUNAL A QUO. INTERPRETAÇÃO IN MALAM PARTEM DO ART. 83, INCISO II, DO CP. VEDAÇÃO.

1. Constatada a lacuna da lei, não pode o aplicador do direito, especialmente no campo do direito penal, optar pela interpretação que mais desfavoreça o réu. Diante da omissão legal, a dúvida há de ser resolvida sempre em benefício do réu. 
2. Assim sendo, como forma de preencher o vazio legal, para a concessão do livramento condicional, deve ser exigido do condenado o mesmo tempo de cumprimento de pena fixado para os primários e de bons antecedentes. Precedentes do STJ.

3. In casu, o ora Paciente já cumpriu mais de $1 / 3$ (um terço) da pena, fazendo, pois, jus ao benefício, já que, constatado o atendimento do requisito subjetivo em primeiro grau, o deslinde da controvérsia não demanda reexame de questões fático-probatórias.

4. Ordem concedida.

A questão central debatida nesse acórdão gira em torno da interpretação do artigo 83, I, do Código Penal. A teor da previsão normativa nele contida, exige-se o cumprimento de um terço da sanção imposta para a concessão de livramento condicional a réu primário. Ocorre que o paciente, embora tecnicamente primário, registra maus antecedentes.

O debate fica resumido na possibilidade de equiparar-se o portador de maus antecedentes com o reincidente, requerendo o cumprimento de metade da sanção imposta para a concessão do benefício.

A Sra. Ministra Relatora entendeu que verificada a lacuna da lei, não poderia o aplicador do direito, especialmente no campo do direito penal, optar pela interpretação que mais desfavoreça o réu, em face da existência de vedação expressa em nosso ordenamento jurídico da chamada analogia in malam partem. Diante da omissão legal, a dúvida haveria de ser resolvida sempre em favor do condenado. O princípio constitucional orientador seria o da liberdade de ir vir.

Assim sendo, como forma de preencher o vazio legal, dado o pressuposto de completude de nosso ordenamento jurídico, deve ser exigido do condenado o mesmo tempo de cumprimento de pena fixado para os primários e de bons antecedentes, qual seja: $1 / 3$ (um terço). Citou precedentes do próprio STJ:

HABEAS CORPUS. EXECUÇÃO PENAL. PEDIDO DE LIVRAMENTO CONDICIONAL. RÉU PRIMÁRIO E COM MAUS ANTECEDENTES. NECESSIDADE DE CUMPRIMENTO DE UM TERÇO DA PENA, E NÃO DE METADE. ARTIGO 83, I, DO CÓDIGO PENAL.

1 - Para a concessão de livramento condicional a réu primário, possuidor de maus antecedentes, ante a falta de previsão legal, como requisito objetivo, exige-se o cumprimento de um terço da sanção imposta, a teor do disposto no artigo 83, inciso I, do Código Penal.

2 - Habeas corpus concedido parcialmente." (HC 28472/DF, 6 ${ }^{a}$ Turma, Rel. Min. PAULO GALLOTTI, DJ de 02/08/2004.) 
"HABEAS CORPUS SUBSTITUTIVO DE RECURSO ORDINÁRIO. HOMICÍDIO QUALIFICADO. FATO ANTERIOR À LEI 8.072/90. REGIME PRISIONAL. QUESTÃO NÃO DECIDIDA PELO TRIBUNAL INDIGITADO COATOR.LIVRAMENTO CONDICIONAL. COMUTAÇÃO. PENAS UNIFICADAS.

O Juízo das Execuções não pode modificar o comando sentencial para afastar a natureza hedionda do crime nela reconhecido, devendo fazê-lo, o Tribunal de Justiça, mediante revisão criminal, ou mesmo através de habeas corpus, se na apelação interposta, sob o estrito fundamento do art. 593, III, d, do Código de Processo Penal, ao argumento de ser a decisão do Júri contrária à prova dos autos, não poderia a Corte admitir nulidades não argüidas formalmente ou modificar a sentença para nova dosagem de pena ou fixação de regime de execução.

Se dos crimes imputados ao paciente e pelos quais foi condenado, apenas um foi considerado hediondo, a execução não pode ser efetuada de maneira uniforme em relação a todos, havendo de separar-se aquele cujo regime é mais rigoroso e em relação ao qual toda a pena já foi cumprida - foi condenado a nove anos e oito meses de reclusão e já purgou mais de dezessete anos, em regime fechado -, certo que, segundo a Lei de regência, as penas mais graves são executadas primeiramente.

o livramento condicional, no caso de ser tecnicamente primário o réu, embora portador de maus antecedentes, tem o prazo de cumprimento de pena regido pelo art. 83, I, do Código Penal, ante a impossibilidade de se equipará-lo ao reincidente. Precedentes do STJ." Ordem concedida em parte para "a) afastar, de ofício, a natureza hedionda do crime de tentativa de homicídio pelo qual o paciente se viu condenado a nove anos e oito meses de reclusão, em regime integral fechado, nos termos do art. $2^{o}$, $\$ 1^{o}$, da Lei $n^{o} 8.072 / 90$, tendo em vista que o fato ocorreu em 04 de março de 1985, a fim de que a execução, unificada, se faça segundo as regras do Código Penal; ou b) declarar extinta a punibilidade do crime tido como hediondo, pelo total cumprimento da pena, prosseguindo-se a execução em relação aos demais, sem as proibições impostas pela Lei $n^{o}$ 8.072/90, de modo a permitir a avaliação da possibilidade de concessão dos benefícios previstos na Lei de Execução Penal e Decretos que concederam indulto, devendo o livramento condicional ser regido pelo art. 83, I, do Código Penal."; Prejudicado o HC 22608/RJ." (HC 25176/RJ, $5^{a}$ Turma, Rel. Min. JOSÉ ARNALDO DA FONSECA, DJ de 05/04/2004.)

"PROCESSO PENAL. PENA. EXECUÇÃO. LIVRAMENTO CONDICIONAL. REQUISITOS. SUBJETIVOS. PRIMARIEDADE. MAUS ANTECEDENTES. OBJETIVOS. CUMPRIMENTO DE 1/3 DA PENA.

Ao condenado primário, portador de maus antecedentes, aplica-se o disposto no artigo 83, inciso I, do Código Penal. Precedentes.

Ordem concedida para afastar a exigência de cumprimento de metade da pena, devolvendo ao Juízo da Execução o exame dos demais requisitos." (HC 26140/RJ, 6 ${ }^{a}$ Turma, Rel. Min. PAULO MEDINA, DJ de 09/12/2003.)

"CRIMINAL. HC. LIVRAMENTO CONDICIONAL. RÉU POSSUIDOR DE MAUS ANTECEDENTES. DIREITO AO LIVRAMENTO CONDICIONAL SIMPLES. NECESSIDADE DE CUMPRIMENTO DE 1/3 DA PENA. PRECEDENTES. LIBERDADE QUE DEVE VIR 
EXPRESSA EM LEI. VEDAÇÃO À INTERPRETAÇÃO AMPLA ÀS REGRAS RESTRITIVAS DE DIREITOS. ORDEM CONCEDIDA.

Ao condenado primário, com maus antecedentes, incide o inc. I do art. 83 do Código Penal, razão pela qual sobressai o direito do paciente ao livramento condicional simples, exigindo-se, além dos requisitos objetivos e subjetivos, o cumprimento de 1/3 da pena. Precedentes.

A liberdade do cidadão deve vir sempre expressa em lei, não se podendo dar interpretação ampla às regras restritivas de direitos, em detrimento do réu.

Deve ser concedido ao paciente o benefício do livramento condicional, mediante as condições previstas na Lei de Execuções Penais, a serem estabelecidas pelo Juizo de $1^{\circ}$ grau. Ordem concedida, nos termos do voto do Relator." (HC 25358RJ, $5^{a}$ Turma, Rel. Min. Gilson Dipp, DJ de 09/06/2003).

Analisando o voto da Sra. Ministra, acompanhado pelos demais membros da Turma, verificamos haver o raciocínio se desenvolvido silogisticamente. O princípio constitucional que garante a liberdade dos cidadãos foi fixado como premissa maior. Esse princípio norteou a escolha da premissa menor, qual seja, a primariedade do réu, porque impõe interpretação restritiva às leis que limitam a liberdade das pessoas.

Esse caso é interessante, porque demonstra que fixado o princípio constitucional como premissa maior, ponto de partida obrigatório para o magistrado, a escolha da premissa menor e de seu termo médio decorrerão do desdobramento de um juízo já realizado, mas virtualizado no princípio. Dessa forma, o fato e sua qualificação jurídica deverão ser revelados e descobertos à luz do princípio e da rodada dialética que ocorre no procedimento processual.

\subsection{Uma invariante axiológica inata (AC 19059 no TRF da $3^{\text {a }}$ Região)}

\subsubsection{Análise do caso}

Trata-se de recurso de apelação interposto por Paulo Roberto Giresini Siviero, condenado, em primeiro grau, a pena de três anos de reclusão, em regime aberto, e multa de $\mathrm{R} \$ 5.200,00$, como incurso nas penas do artigo $4^{\circ}$, parágrafo único, da Lei $7.492 / 86$. 
A Segunda Turma do Tribunal Regional Federal da Terceira Região, por unanimidade, deu provimento ao recurso para absolvição do réu Paulo Roberto Giresini Siviero com fulcro no art. 386, III, do Código Penal e, nos termos do art. 580 do Código de Processo Penal, estendeu os efeitos da absolvição ao réu Iran Barbosa Chaves. Votaram com o relator os desembargadores Cotrim Guimarães e Cecília Mello.

O caso pode ser assim resumido: Paulo Roberto Giresini Siviero, Anézia Barbosa Chaves e Iran Barbosa Chaves foram denunciados como incursos no artigo $4^{\circ}$, parágrafo único da Lei 7.492/86 porque, quando do afastamento para gozo de férias do Gerente Geral da agência da Caixa Econômica Federal da rua 13 de Maio, assumiu estas funções o acusado Paulo Roberto Giresini Siviero que desencadeou a gestão temerária da instituição financeira.

Tendo se relacionado com os demais acusados, Anézia e Iran, proprietários da Firma Texas Transportes Ltda., com estes fez inúmeras operações financeiras sem garantias, ou qualquer formalidade, critério ou bom senso, descumprindo reiteradamente normas e atos da administração da CEF, objetivando unicamente beneficiar os demais denunciados. Até o momento não se apuraram as vantagens que porventura tenham auferido às custas dos prejuízos que acarretou a Instituição, montando em mais US\$ 1.000.000 (um milhão de dólares americanos).

Os acusados Anézia e Iran, sabedores que os empréstimos obtidos por intermédio do primeiro acusado não poderiam ser pagos, já que não percebiam receitas suficientes para honrar a dívida, em suas mais variadas modalidades, ainda assim continuaram nas operações temerárias, lançando mão de artifícios relativos a garantias insubsistentes.

A sentença proferida é de absolvição de Anézia Barbosa Chaves na forma do artigo 386, VI do CPP e condenação de Paulo Roberto Giresini Siviero e Iran Barbosa Chaves pelo delito capitulado na inicial a sanções de três anos de reclusão e multa de R\$ $5.200,00$, estabelecido o regime inicial aberto

Apelou o réu, pleiteando sua absolvição, dizendo ter agido de modo semelhante, em ocasiões anteriores com bons resultados à $\mathrm{CEF}$, que a empresa tomadora possuía bom patrimônio e por conta da inflação ocorrendo o inadimplemento, que os empréstimos apontados configuravam rolagem de dívida, que na apuração administrativa 
não se vislumbrou dolo ou improbidade, alternativamente pedindo a redução da pena privativa de liberdade e exclusão da multa ${ }^{175}$.

O acórdão vem assim ementado:

PENAL. CRIMES CONTRA O SISTEMA FINANCEIRO. GESTÃO TEMERÁRIA. GERENTE DE AGÊNCIA BANCÁRIA.

- As violações ao Sistema Financeiro Nacional praticadas na gestão de instituições financeiras são crimes próprios, só as pessoas incluídas no rol do artigo 25 da Lei 7.492/86 podendo figurar como autores e, cumprida essa condição, então possibilitando-se a participação de terceiros.

- Nos delitos que têm como conteúdo condutas praticadas na gestão de instituição financeira é esta como um todo que deve ser considerada, para que um ato possa ser imputado à instituição financeira como um todo exigindo-se sua prática por quem detenha poderes gerais de mando, só nestas condições podendo-se alvitrar o evento de danos ao Sistema Financeiro Nacional.

- A concepção da definição legal do delito que é de gestão da instituição financeira já limita o conceito da qualificação pessoal exigida ao círculo de agentes com poderes gerais e superiores de decisão e reforça este entendimento a objetividade jurídica. Bens objeto da proteção penal que estão na política econômica do governo e estabilidade e segurança do mercado em face dos quais não se concebe eventos de lesão a semelhantes interesses em condutas praticadas por funcionários que não integram a cúpula e que por si sós não podem causar prejuízos de modo a pôr a instituição financeira, que como tal só pode ser reconhecida no todo, em risco com correlatos resultados de abalos no SFN.

- O Direito em geral e mais ainda o Direito Penal não se concebe sem definições de condutas que compõem o conteúdo das normas.

E o princípio da legalidade aplica-se com mais vigor no Direito Penal, que não admite a integração por analogia. Interpretação da lei no prisma do bem jurídico e também do conceito de gestão de instituição financeira na alvitrada subordinação à prática de atos

qualificados pela competência ampla e geral do agente administrador que impõe a exegese restritiva do vocábulo "gerente".

- Recurso provido para absolvição do réu apelante, com extensão ao acusado que não recorreu, nos termos do artigo 580 do CPP.

O tema central discutido no acórdão diz respeito à interpretação do termo gerente, constante do artigo 25 da Lei 7.492/86. Analisando a questão, notadamente os critérios hermenêuticos próprios do Direito Penal, assim se pronunciou o Desembargador Peixoto Júnior:

\footnotetext{
${ }^{175}$ Relatório extraído do voto do Desembargador Peixoto Júnior.
} 
“...O caso dos autos é de imputação de gestão temerária de instituição financeira feita a agente na condição de gerente geral de agência da CEF.

As violações ao Sistema Financeiro Nacional praticadas na gestão de instituições financeiras são crimes próprios, só as pessoas incluídas no rol do artigo 25 da Lei 7.492/86 podendo figurar como autores e, cumprida essa condição, então possibilitando-se a participação de terceiros.

$\mathrm{O}$ réu condenado era um gerente de agência, funcionário da CEF com vínculo empregatício e nesta condição não praticou atos de gestão no sentido penal.

Ilustra este entendimento comentários de Manoel Pedro Pimentel, "verbis":

"4. Nos termos do art. 25 da lei sob exame, podem ser sujeitos ativos das infrações nela descritas, como sujeitos ativos próprios, "o controlador e os administradores de instituição financeira, assim considerados os diretores, gerentes". Entendemos que o vocábulo gerente somente designa os agentes responsáveis pela condução da instituição financeira, na administração superior da empresa, e não os gerentes executivos, assalariados, que respondem por agências ou filiais, sem autonomia e poder de decisão nas questões relevantes da vida empresarial. É claro que esta ressalva cabe apenas em relação aos crimes que disserem respeito aos comportamentos especificados na lei, em que a cobrança de responsabilidade se faça relativamente às decisões de cúpula, uma vez que mesmo os gerentes de agências ou de filiais serão sujeitos ativos em outras infrações previstas nesta lei especial. A questão deverá ser examinada caso a caso, tentando-se para esta observação que acabamos de fazer." (Comentários à Lei 7.492, de 16.06.86, p. 175. Edit. Revista dos Tribunais: 1987.)

Faz parte da função e do cotidiano de um gerente de agência decidir sobre empréstimos mas isto não faz dele um dirigente da instituição financeira.

A esfera pessoal de validade da norma punindo a autoria da gestão temerária restringe-se aos órgãos de direção da instituição financeira. Os atos de gestão sob a incidência da norma penal não se equiparam a decisões de gerentes executivos. Teoricamente podem estar ocasionando prejuízos à instituição financeira mas outro é o significado da lei penal que só considera lesivos ao Sistema Financeiro Nacional os atos praticados pelos órgãos de direção e administração.

O delito imputado tem como conteúdo condutas praticadas na gestão das instituições financeiras e, destarte, é a instituição financeira como um todo que deve ser considerada. E para que um ato possa ser imputado à instituição financeira como um todo é preciso que seja praticado por quem detenha poderes gerais de mando.

A concepção da definição legal do delito que é de gestão da instituição financeira já limita o conceito da qualificação pessoal exigida ao círculo de agentes com poderes gerais e superiores de decisão e reforça este entendimento a objetividade jurídica. Com efeito, os bens objeto da proteção penal estão na política econômica do governo e estabilidade e segurança do mercado, daí não se concebendo eventos de lesão a semelhantes interesses em condutas praticadas por funcionários que não integram a cúpula e que por si sós não podem causar prejuízos de modo a pôr a instituição financeira, que como tal só pode ser reconhecida no todo, em risco com correlatos resultados de abalos no SFN. 
Um gerente de agência não passa disto, gere a agência, não a instituição financeira. Esta é gerida por seus diretores, pelo escalão superior, por administradores com amplitude de poderes abrangentes da instituição financeira em toda a sua extensão. $\mathbf{O}$ Direito em geral e mais ainda o Direito Penal não se concebe sem definições de condutas que compõem o conteúdo das normas. $E$ o princípio da legalidade aplicase com mais vigor no Direito Penal, que não admite a integração por analogia. A interpretação da lei no prisma do bem jurídico protegido e também do conceito de gestão de instituição financeira na alvitrada subordinação à prática de atos qualificados pela competência ampla e geral do agente administrador a meu juízo impõe a exegese restritiva do vocábulo "gerente".

Condutas praticadas por gerente executivo de agência bancária ficaram de fora do âmbito de autoridade da lei. A norma penal não contempla atos de gerência de agência bancária e não pune os empregados exercentes dessas funções.

Pode, a exemplo, ser o gerente responsabilizado penalmente por delito do artigo 19, alvitrando-se hipótese de cumplicidade com o beneficiário de financiamento obtido mediante fraude mas em tipos penais em cuja definição de algum modo entra o ente corporativo, a instituição financeira, não se possibilita a prática por agente nestas condições porque não representa e seus atos não são de gestão da instituição financeira.

Concluo, destarte, pela atipicidade da conduta, aplicando-se ao caso o art. 386, III do CPP.

Diante do exposto, dou provimento ao recurso para absolvição do réu apelante, com extensão ao acusado que não recorreu, nos termos do artigo 580 do CPP....".

\subsubsection{A facilidade com que se aplica o princípio da legalidade}

Neste caso, o julgador desenvolveu um silogismo. Vemos que o princípio constitucional da legalidade foi fixado como premissa maior e da sua escolha decorreu a fixação da premissa menor, qual seja, a exegese restritiva do termo gerente.

O raciocínio foi aparentemente simples, porque o princípio da legalidade adquiriu ao longo do processo histórico da humanidade tamanha intangibilidade que se apresenta como uma invariante axiológica inata ${ }^{176}$ e dele decorre a proibição da aplicação da analogia contra o réu.

A Constituição do Brasil de 1988 caracteriza-se pela incorporação de princípios gerais, voltados para indicar um sentido de direção que a Constituição busca

\footnotetext{
${ }^{176}$ REALE, Miguel. Teoria tridimensional do direito, teoria da justiça, fontes e modelos do direito, cit., p. 315.
} 
imprimir à sociedade brasileira. Os princípios constitucionais são normas que nos obrigam a agir ou a decidir, em função do valor objetivo do bem visado por nossa ação ou decisão, ou do seu objetivo final que, no caso brasileiro, é a construção de uma sociedade livre, justa e solidária, o desenvolvimento nacional, a erradicação da pobreza e a marginalização, redução das desigualdades sociais e regionais, assim como a promoção do bem estar de todos, sem preconceitos de raça, cor, sexo, origem, idade e quaisquer outras formas de discriminação. Esse objetivo final resume-se nos valores consagrados pela Constituição Federal e não um interesse puramente subjetivo que o magistrado pode ou não compartilhar com a comunidade.

A Dogmática moderna avaliza o entendimento de que as normas se enquadram em duas categorias diversas: os princípios e as regras. ${ }^{177}$ Enquanto as regras, como aponta Gustavo Zagrebelsky, proporcionam-nos critérios específicos sobre como devemos, não devemos ou podemos atuar em determinadas situações, os princípios, em contraste, proporcionam-nos critérios para tomar uma posição diante de situações concretas que, no entanto, a priori, são indeterminadas, só adquirindo significado operativo no momento de sua aplicação a um caso concreto, pois a elas não se pode atribuir uma determinação em abstrato. Nesta tomada de posição os princípios são, como diria Alexy, mandatos de otimização dos valores consagrados. ${ }^{178}$

Logo, os princípios constitucionais como normas indicam valores a serem preservados ou fim a serem alcançados pela sociedade. Nesse contexto, o sentido da norma deve ser encontrado através dos elementos do caso concreto analisados à luz dos princípios constitucionais. Trata-se da expansão axiológica do Direito rompendo a clivagem entre Direito e Valor.

Todavia, podemos afirmar que a conquista do princípio da legalidade como invariante axiológica foi lenta, afirmando-se pelo hábito e consenso na sua aplicação, o que esperamos também venha a acontecer com os direitos humanos sociais, cuja aplicação ainda não é automática como percebemos com o princípio da legalidade, já internalizado no universo cultural dos juízes.

\footnotetext{
${ }^{177}$ BARROSO, Luis Roberto; BARCELLOS, Ana Paula. op. cit., p. 101-135.

${ }^{178}$ LAFER, Celso. A Constituição de 1988 e as relações internacionais: reflexões sobre o art. $4^{\text {o }}$, cit., p. 11. (cf. ALEXY, Robert. A theory of constitucional rights, cit.).
} 


\subsection{A supremacia da constituição: uma tecnologia em construção (HC 44.165 - RS)}

Trata-se de habeas corpus impetrado por Décio Gonçalves Torres Freire e outros em favor de Gilberto dos Santos Portugal contra ato coator do Sr. Desembargador Federal relator do Habeas Corpus n. 200504010153704 do Tribunal Regional Federal da $4^{\text {a }}$ Região consistente em negar ao impetrante acesso aos autos de inquérito em função da necessidade de sigilo, uma vez que ele prossegue na oitiva de suspeitos e envolvidos nos fatos sob investigações, recusa esta devidamente fundamentada.

Os Ministros da Sexta Turma do Superior Tribunal de Justiça concederam a ordem nos termos do voto do Sr. Ministro Nilson Naves. Os Srs. Ministros Paulo Gallotti e Maria Thereza de Assis Moura acompanharam a relatoria. Vencido o Sr. Ministro Hamilton Carvalhido, que não conheceu da ordem.

Diz a ementa do acórdão:

Inquérito policial (acesso aos autos). Sigilo das investigações (relatividade). Incompatibilidade de normas (antinomia de princípio). Defesa (ordem pública primária).

1.Há, no nosso ordenamento jurídico, normas sobre sigilo, bem como normas sobre informação; enfim, normas sobre segurança e normas sobre liberdade.

2.Havendo normas de opostas inspirações ideológicas - antinomia de princípio -, a solução do conflito (aparente) há de privilegiar a liberdade. Afinal, somente se considera alguém culpado após o trânsito em julgado de sentença penal condenatória.

3.A defesa é de ordem pública primária (Carrara); sua função consiste em ser a voz dos direitos legais - inocente ou criminoso o acusado.

4.De mais a mais, é direito do advogado examinar autos de flagrante e de inquérito, findos ou em andamento (Lei n ${ }^{\circ} 8.90694$, art. $7^{\circ}$, inciso XIV).

5.A Turma ratificou a liminar - de caráter unipessoal - e concedeu a ordem a fim de permitir ao advogado vista, em cartório, dos autos de inquérito.

O tema central debatido nesse caso consiste na possibilidade de se negar ao indiciado vista dos autos do inquérito policial, na medida em que pendem investigações contra ele. Verificamos que o relator, ao analisar a questão, pondera que, havendo conflito entre dois princípios - o da segurança e o da liberdade - é o da liberdade que deve prevalecer sempre. O magistrado iniciou seu raciocínio pelos princípios da dignidade humana e da presunção de inocência, assegurando e resguardando a ambos. 
Vejamos os critérios de interpretação do Sr. Ministro Relator:

“... (I) 'todos têm direito a receber dos órgãos públicos informações de seu interesse particular, ou de interesse coletivo ou geral, que serão prestadas no prazo da lei, sob pena de responsabilidade, ressalvadas aquelas cujo sigilo seja imprescindível à segurança da sociedade e do Estado" (Constituição, art. 5', XXXIII); (II) 'a autoridade assegurará no inquérito o sigilo necessário à elucidação do fato ou exigido pelo interesse da sociedade' (Cód. de Pr. Penal, art. 20). S. Exa. também recordou o inciso LX do rol dos direitos e deveres, segundo o qual 'a lei só poderá restringir a publicidade dos atos processuais quando a defesa da intimidade ou o interesse social o exigirem'. Atentemos também para estoutra observação: no caso de que ora estamos cuidando, as razões do indeferimento constam do relatório.

Contudo, quando daquela concessão de liminar, lembrei outras proposições (que dizem respeito à dignidade da pessoa humana), entre as quais: (a) "são invioláveis a intimidade, a vida privada, a honra e a imagem das pessoas, assegurado o direito a indenização pelo dano material ou moral decorrente de sua violação" (inciso X); (b) "aos litigantes, em processo judicial ou administrativo, e aos acusados em geral são assegurados o contraditório e ampla defesa, com os meios e recursos a ela inerentes" (inciso LV); (c) "ninguém será considerado culpado até o trânsito em julgado de sentença penal condenatória" (inciso LVII). Escrevi então:

2. O entendimento que tenho da questão de caráter legal e constitucional é diferente do acima exposto. Na existência do indicado conflito, a solução que se me afigura melhor é a favor da liberdade. Já escrevi: 'Jamais percamos de vista que, entre os direitos e garantias fundamentais de nossa Constituição, encontra-se inscrito que 'ninguém será considerado culpado até o trânsito em julgado de sentença penal condenatória'. Aliás, o postulado axiológico da presunção de inocência, por ser eterno, universal e imanente, nem precisaria estar gravado em texto normativo'. Há mais: a inviolabilidade de direitos que dizem com a dignidade da pessoa humana, e a dignidade é um dos fundamentos em que se assenta a República Federativa do Brasil. Há mais: e a ampla defesa? Institutoprincípio que também se inscreve entre os postulados universais e que 'não é de hoje, não é de ontem, é desde os tempos mais remotos...' Perdoem-me os pensamentos contrários, mas, quando existe o conflito, devemos solvê-lo em prol da liberdade."

Escreveu Bobbio, versando sobre as chamadas antinomias impróprias especificamente, antinomia de princípio - ("Teoria do ordenamento jurídico", pág. 90):

"Fala-se de antinomia no Direito com referência ao fato de que um ordenamento jurídico pode ser inspirado em valores contrapostos (em opostas ideologias): consideram-se, por exemplo, o valor da liberdade e o da segurança como valores antinômicos, no sentido de que a garantia da liberdade causa dano, comumente, à segurança, e a garantia da segurança tende a restringir a liberdade; em conseqüência, um ordenamento inspirado em ambos os valores se diz que descansa sobre princípios antinômicos. Nesse caso, pode-se falar de antinomias de princípio. As antinomias de princípio não são antinomias jurídicas propriamente ditas, 
mas podem dar lugar a normas incompatíveis. É lícito supor que uma fonte de normas incompatíveis possa ser o fato de o ordenamento estar minado por antinomias de princípio."

É o que ocorre no caso de que estamos cuidando. Quanto a ser real ou ser aparente a incompatibilidade, as referências são no sentido de que se trata de normas aparentemente incompatíveis, normas que hão, pois, de ser conservadas no sistema e são, uma vez verificado o conflito - aparente, pelo visto -, de interpretação a favor da liberdade. Foi o que eu disse quando concedi liminar ao paciente.

Faço duas citações - pertinentes, ao que penso. Escreveram Francesco Carrara (1805-1888) e Rui Barbosa (1849-1923):

(I) "A este princípio se associa o outro, de que a sociedade também tem direto interesse na defesa do acusado, por necessitar, não de uma pena que recaia sobre qualquer cabeça, mas da punição do verdadeiro culpado. Assim, a defesa não é apenas de ordem pública secundária, mas também de ordem pública primária." ("Programa do curso de Direito Criminal", Parte Geral. Campinas: LZN, vol. II, pág. 450.)

(II) "Ora, quando quer e como quer que se cometa um atentado, a ordem legal se manifesta necessariamente por duas exigências, a acusação e a defesa, das quais a segunda, por mais execrando que seja o delito, não é menos especial à satisfação da moralidade pública do que a primeira. A defesa não quer o panegírico da culpa, ou do culpado. Sua função consiste em ser, ao lado do acusado, inocente, ou criminoso, a voz dos seus direitos legais.

Se a enormidade da infração reveste caracteres tais, que o sentimento geral recue horrorizado, ou se levante contra ela em violenta revolta, nem por isto essa voz deve emudecer. Voz do Direito no meio da paixão pública, tão susceptível de se demasiar, às vezes pela própria exaltação da sua nobreza, tem a missão sagrada, nesses casos, de não consentir que a indignação degenere em ferocidade e a expiação jurídica em extermínio cruel." ("O dever do advogado". Rio de Janeiro: Aide, págs. 40/41.)

Está escrito o seguinte na Exposição de Motivos do Cód. de Pr. Penal:

"... este se norteou no sentido de obter equilíbrio entre o interesse social e o da defesa individual, entre o direito do Estado à punição dos criminosos e o direito do indivíduo às garantias e seguranças de sua liberdade."

Tal a missão reservada à defesa - vejam que de ordem pública primária e de caráter sagrado - e tal o equilíbrio a ser observado entre os dois interesses - o social e o da defesa -, não deparo com outra compreensão do caso sob nossos olhos senão a de admitir tenha o advogado direito de acesso a autos de inquérito policial, a despeito do caráter desse processo preliminar - instrução provisória que antecede à propositura da ação penal. Além disso, é direito do advogado, reza a Lei $\mathrm{n}^{\circ}$ 8.90694, 'examinar em qualquer repartição policial, mesmo sem procuração, autos de flagrante e de inquérito, findos ou em andamento, ainda que conclusos à autoridade, podendo copiar peças e tomar apontamentos (inciso XIV do art. $\left.7^{\circ}\right)^{\prime} . "$ 
Observamos até agora que toda decisão judicial representa um ato de interação social entre o Poder Judiciário e a sociedade que o criou, motivo por que é necessário que o juiz expresse com clareza e sinceridade suas razões e descreva o caminho por ele percorrido entre as alegações das partes e os fatos julgados relevantes para a causa, bem como indique os princípios orientadores do seu raciocínio. ${ }^{179}$

No caso apresentado, encontramos os princípios da presunção da inocência e da liberdade elevados à categoria de premissa maior pelo julgador. Diversamente do que ocorreu no $\mathrm{HC}^{\circ}$ 56.975/PA (primeiro caso examinado), este foi analisado e julgado à luz de um princípio positivado na Constituição.

Podemos dizer que os fundamentos e objetivos fundamentais, inseridos no preâmbulo e nos artigos $1^{\circ}$ e $3^{\circ}$ da Constituição Federal, materializam opções ideológicas cuja implementação somente se viabiliza ao longo do tempo. Mas nem por isso a Constituição da República deve converter-se em aventura frustrante, seus princípios e sua metas qualificados como meros conselhos, proposições ou recomendações, porque, em sua força normativa, o diploma constitucional é estatuto de garantia e estabilidade do projeto de vida de todos aqueles que a seus comandos estão submetidos. ${ }^{180}$

Nesse sentido, a segurança jurídica da vinculação do juiz à Constituição é indispensável para os governantes e para os governados. "Para os governantes, a fim de que possam desempenhar plenamente suas atribuições, usando com o máximo de eficácia os instrumentos legais, tendo a certeza de que não irão sofrer, mais tarde, as conseqüências dos atos que tiverem praticado como agentes do poder público." "Para os governados é, talvez, mais evidente a necessidade de segurança jurídica, para que, sob o pretexto de razão de Estado, não sofram o atributo e a violência, ficando à mercê de autoridades mal preparadas, desprovidas de espírito público, incapazes de compreender seu papel de órgão social, ou, o que não é raro, empolgadas com a possibilidade de exibirem alguma superioridade." 181

Realmente, o sistema que nos serviu de modelo, ao implantarmos a República, assenta na supremacia da Constituição. Ela incorpora princípios gerais voltados a indicar uma direção que busca imprimir à sociedade brasileira. Nesse sentido, os

\footnotetext{
${ }^{179}$ MARTINS, Samir José Caetano. Neoconstitucionalismo e seus reflexos no dever de fundamentação das decisões judiciais no Brasil. Revista Dialética de Direito Processual, São Paulo, n. 44, p. 119, nov. 2006.

${ }^{180}$ FANTONI JÚNIOR, Neyton. op. cit., p. 846.

${ }^{181}$ DALLARI, Dalmo de Abreu. Segurança e direito. In: aplicação do direito, direito e política. 2. ed. São Paulo: Saraiva, 1980. p. 26.
} 
princípios gerais passam a ter uma função axiológica para o Direito e para o seu intérprete $^{182}$.

Esses valores já positivados e conquistados ao longa da história do homem devem conduzir o magistrado na fixação do sentido da norma e na qualificação jurídica do fato. Isso é muito importante, porque o critério para qualificação jurídica do fato e da norma jurídica aplicável repousa no enfoque dado pelo magistrado. E, nesse passo, tornase necessário impedir que certos apriorismos ou preconceitos possam modelar a realidade mais a nosso sabor e às nossas condições do que espelhar a realidade independentemente de nós. Atingir esse ponto, de forma a distinguir quando a realidade é uma projeção da nossa mente e quando a realidade é testemunho de si própria, talvez seja uma das tarefas mais difíceis do juiz ${ }^{183}$, razão pela qual o paradigma do pensamento e do raciocínio do magistrado deve ser a Constituição e seus princípios e não aqueles que lhes são privativos ou particulares.

Realmente, embora a ninguém surpreenda a tese da supremacia da Constituição, o fato é que a convivência efetiva da normativa constitucional é algo cuja tecnologia está em construção. A própria incidência direta da Constituição sobre as relações Estado-particulares, abre, operacionalmente, um campo fértil de dúvidas, em especial pela ausência de tradição de manejar normas de teor semântico menos preciso.

O direito atual é o direito do heterogêneo e do plural. A heterogeneidade está na Constituição, como resultado multiforme de tendências díspares; a heterogeneidade está nos valores, nem sempre conciliáveis, a exigir ponderação; a heterogeneidade está nas fontes normativas, a heterogeneidade está nos sujeitos de direito, que deixaram de ser uma figura uniforme para assumir a condição de uma pluralidade concreta: consumidor, possuidor, contratante, doente, idoso, estudante, criança - todos merecendo uma proteção diferenciada.

Há uma percepção difusa, porém progressiva, da perda de certeza e de previsibilidade, como elementos chaves do sistema jurídico, resultante de uma polissemia irritante da época pós moderna, focada no anseio que um conceito signifique algo e ao mesmo tempo o seu contrário.

\footnotetext{
${ }^{182}$ LAFER, Celso. A Constituição de 1988 e as relações internacionais: reflexões sobre o art. 4º cit., p. 4-5.

${ }^{183}$ SANTOS, Mario Ferreira dos. op. cit., p. 214.
} 
De toda sorte, é preciso cuidado ao falar que estamos em crise, porque ela pouco explica. A tendência de projetar as características de uma época como características perenes torna o conceito de crise um termo recorrente.

Não vivemos uma crise. A vida é a realidade infinita e nunca lhe assentaram com irrepreensível justeza as roupas feitas da lei e os figurinos da doutrina. Se o juiz não der de si para dizer o direito em face da diversidade de cada caso, a sua justiça será a do leito de Procusto: ao invés de medir-se com os fatos, estes é que terão de medir-se com ela . ${ }^{184}$ Essa sempre foi e continua sendo a realidade do magistrado, não significando, com isso, que o Direito esteja sempre em crise.

\subsection{Duas conclusões díspares (REsp 783.427-DF)}

\subsubsection{Análise do caso}

Trata-se de acórdão do Superior Tribunal de Justiça proferido em sede de recurso especial. O caso pode ser assim resumido: Paulo Afonso Romano ajuizou ação de rito ordinário contra a União Federal, objetivando a devolução das contribuições previdenciárias recolhidas ao Instituto de Previdência dos Congressistas - IPC --, extinto pela Lei 9.506, de 30 de outubro de 1997, no período de setembro de 1991 a março de 1994, ocasião em que o recorrente exerceu o mandato de deputado federal.

O Instituto de Previdência dos Congressistas foi criado pelo Congresso Nacional, por meio da Lei 4.284/63, com o objetivo de propiciar aos seus segurados obrigatórios ou facultativos um regime previdenciário próprio, com os benefícios de pensão, auxílio-doença, auxílio-funeral, dentre outros, observado o período de carência de oito anos de contribuição.

Nos termos da lei, são segurados obrigatórios do IPC os congressistas e, quando em exercício, os suplentes de deputados e senadores. Segurados facultativos, por sua vez, são os servidores integrantes do quadro de filiados e os servidores do Senado Federal e de seus órgãos supervisionados, e os da Câmara dos Deputados que se inscreveram como filiados a partir da data da entrada em vigor da citada lei.

\footnotetext{
${ }^{184}$ HUNGRIA, Nelson. op. cit., v. 1, t. 1, p. 63.
} 
A edição da Lei 7.087/82 veio consolidar o conjunto de normas referentes ao IPC em vigor até aquela data.

\section{[...]}

Art. 21 - São segurados obrigatórios do IPC, independentemente de idade e de exame de saúde, os Congressistas e, quando em exercício, os suplentes de Deputado e Senador.

Art. 23 - O período de carência para concessão de pensão é de oito anos de contribuição.

Art. 24 - O segurado obrigatório que, ao término do exercício do mandato, não haja cumprido o período de 8 (oito) anos, consecutivos ou alternados, e o segurado facultativo que se desligar do órgão ao qual pertença, poderão continuar contribuindo mensalmente, com as partes correspondentes ao segurado e ao órgão, ate completar o período de carência ou a idade estabelecida no art. 34 desta Lei, devendo estas contribuições integrais receber os reajustes proporcionais à majoração do valor-base de cálculo.

Parágrafo único - O prazo para habilitação à continuidade da contribuição de carência é de 6 (seis) meses, improrrogável, a contar do dia imediato ao fim do mandato ou exercício de mandato ou do dia do desligamento.

Art. 25 - Ao segurado que desistir de pagar o restante da carência, que cancelar ou tiver cancelada sua inscrição, não serão restituídas as contribuições já feitas, podendo, no entanto, reinscrever-se no IPC.

$\S 1^{\circ}$ - Os que se tornarem segurados mediante reinscrição, inclusive os pensionistas serão considerados para todos os efeitos legais, como se inscritos pela primeira vez no IPC.

$\S 2^{\circ}-\mathrm{O}$ disposto no parágrafo anterior não se aplica aos antigos segurados obrigatórios que venham a ser reinscritos na mesma categoria, que terão as contribuições anteriores consideradas para todos os efeitos legais, desde que satisfeitas as exigências constantes do art. 26 desta Lei. $[\ldots]$

Em outubro de 1997, o Congresso editou a Lei $\mathrm{n}^{\circ} 9.50697^{185}$ que previu a liquidação definitiva do IPC em $1^{\circ}$ de fevereiro de 1999, estabelecendo, dentre outros, as regras para a devolução das contribuições feitas pelos segurados e ex-segurados.

\footnotetext{
${ }^{185} \S 5^{\circ}$ A Casa Legislativa ou órgão a que se vinculou o segurado ressarcirá as contribuições por este recolhidas ao IPC, atualizadas monetariamente, mês a mês, pelos índices de remuneração das cadernetas de poupança no prazo de sessenta dias:

I - a partir de $1^{\circ}$ de fevereiro de 1999 , aos atuais congressistas que o requererem;

II - a partir de $1^{\circ}$ de fevereiro de 1999 , aos atuais segurados facultativos que não tiverem adquirido direito à pensão, na forma da legislação vigente até a data de publicação desta lei;

III - a partir de $1^{\circ}$ de fevereiro de 1999, aos ex-segurados que, embora tenham adquirido direito à pensão, não o tenham exercido e desde que optem, em detrimento deste, pelo ressarcimento previsto neste parágrafo.
} 
De acordo com o mencionado dispositivo, somente poderiam requerer o ressarcimento das contribuições recolhidas ao fundo os congressistas investidos em mandato parlamentar quando da sua edição - ainda que não contribuído com o tempo de carência - e os ex-segurados obrigatórios que haviam adquirido direito à pensão por terem contribuído com o tempo mínimo necessário de 08 (oito) anos.

Consectariamente a lei deixou de prever, expressamente, a hipótese dos excongressistas que não haviam contribuído com o tempo mínimo de carência.

Na hipótese vertente, o autor era segurado obrigatório do mencionado instituto e contribuiu com o IPC no período de set91 a mar94, cuja interpretação literal do $\S 5^{\circ}$, do art. $1^{\circ}$, da Lei 9.50697 não o ampara à devolução dos valores recolhidos, a título de contribuição do IPC.

O juízo de primeira instância indeferiu o pedido, razão pelo qual foi interposto recurso de apelação.

O Tribunal Regional Federal da $1^{\text {a }}$ Região, por maioria de votos, negou provimento ao apelo, confirmando a sentença de primeira instância porque

\begin{abstract}
“A Lei $n^{\circ}$ 9.506/97, ao extinguir o IPC, previu o ressarcimento somente aos ex-segurados, não contribuintes facultativos, que, embora tenham adquirido o direito à pensão, não o exerceram, não cabendo ao Poder Judiciário a função de legislador positivo:

"Não cabe ao Poder Judiciário, em tema regido pelo postulado constitucional da reserva de lei, atuar na anômala condição de legislador positivo (RTJ 126/48 - RTJ 143/57 - RTJ 146/461-462 - RTJ 153/765 - RTJ 161/739-740 - RTJ 175/1137, v.g.), para, em assim agindo, proceder à imposição de seus próprios critérios, afastando, desse modo, os fatores que, no âmbito de nosso sistema constitucional, só podem ser legitimamente definidos pelo Parlamento. É que, se tal fosse possível, o Poder Judiciário - que não dispõe de função legislativa - passaria a desempenhar atribuição que lhe é institucionalmente estranha (a de legislador positivo), usurpando, desse modo, no contexto de um sistema de poderes essencialmente limitados, competência que não lhe pertence, com evidente transgressão ao princípio constitucional da separação de poderes.' (STF, RE 322348 /SC, Rel. Min. CELSO DE MELLO, T2, unânime, DJ 06/12/2002, p. 74)".
\end{abstract}

O STJ, no entanto, julgou procedente o recurso especial, reformando a decisão do Tribunal da $1^{\text {a }}$ Região em acórdão assim ementado:

PREVIDENCIÁRIO. INSTITUTO DE PREVIDÊNCIA DOS PARLAMENTARES - IPC. EXTINÇÃO. RESTITUIÇÃO DE 


\section{CONTRIBUIÇÕES. DIREITO DOS ANTIGOS E ATUAIS CONGRESSISTAS}

1. O Direito Tributário contém regras de hermenêutica para as hipóteses de lacunas legais, determinando em seu art. 108, verbis: Na ausência de disposição expressa, a autoridade competente para aplicar a legislação tributária utilizará sucessivamente, na ordem indicada: I - a analogia; II - os princípios gerais de direito tributário; III - os princípios gerais de direito público; $I V$ - a equidade. $\$ \S 1^{\circ}$ e $2^{\circ}(\ldots)$.

2. A Lei $n^{\circ} 9.506 / 97$, ao extinguir o IPC e disciplinar o ressarcimento das verbas a ele recolhidas a título de contribuição dos segurados, omitiu-se quanto à situação do ex-segurados não detentores do direito à pensão.

3. É princípio basilar de direito público a isonomia, mercê cláusula pétrea, admitindo-se na omissão da lei a analogia e a eqüidade.

4. À luz desses cânones, revela-se injusta a interpretação literal dada à norma indigitada do art. $1^{o}$, $\$ 5^{\circ}$, da Lei $n$. 9.506/97, porquanto discrimina ex-congressistas em situações idênticas.

5. $O$ direito dos contribuintes ao ressarcimento das contribuições recolhidas ao IPC visou precipuamente o princípio básico do direito previdenciário da contra-prestação, evitando o enriquecimento sem causa do fundo. Precedente: (Resp. $n^{o}$ 638514/DF. Rel. Min. José Delgado. DJU: 16.08.2004; Resp. $n^{\circ}$ 427223/DF. Rel. Min. João Otávio de Noronha. DJU. 20.10.2003).

6. Recurso Especial provido.

O Ministro relator articulou o seu discurso decisório nos seguintes termos:

“...Cinge-se a controvérsia, assim, acerca do direito do ex-congressista, ora recorrente, em se ver ressarcido das contribuições efetuadas para o Instituto de Previdência do Congresso - IPC pelo período em que exerceu o mandato de deputado federal.

Sob esse ângulo, assume relevo a localização da matéria constitucional no afã de aferir a que vetor principiológico pertence, para que, observando o princípio maior, a partir dele, transitar pelos princípios específicos, até o alcance da norma infraconstitucional.

Consectariamente, a exegese da legislação infraconstitucional deve, sempre que possível, curvar-se à força normativa da Carta Maior.

Consoante é de sabença, o Instituto da Previdência Social, ainda que de natureza privada, estabelece suas bases no instrumento de política social do governo (CF. art. 195), sendo certo que sua finalidade primeira é a manutenção do nível de renda do trabalhador em casos de infortúnios ou de aposentadoria, abrangendo atividades de seguro social definidas como aquelas destinadas a amparar o trabalhador nos eventos previsíveis ou não, como velhice, doença, invalidez: aposentadorias, pensões, auxíliodoença e auxílio-acidente do trabalho, além de outros benefícios ao trabalhador.

É nesse sentido, portando, que o dispositivo in focu deve ser interpretado, de modo a abranger a finalidade do instituto, consubstanciado nos fins sociais e na exigência do bem comum (LICC, art. $5^{\circ}$ ). 
A Segunda Turma desta E. Corte Superior já teve a oportunidade de se manifestar em hipótese idêntica à versada no presentes autos, em acórdão que assim restou ementado:

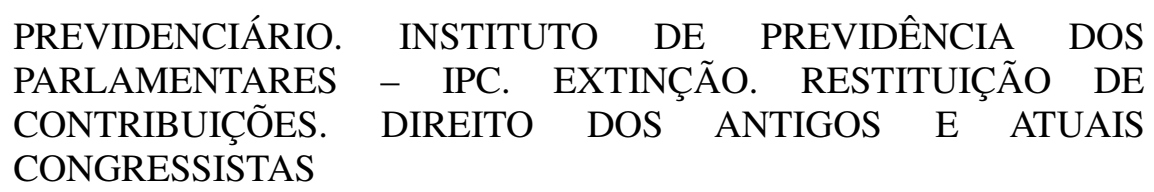

1. Ao Judiciário cumpre suprir a omissão legal, observados os primados jurídicos aplicáveis e tendo sempre em mira o viés social e político da Tutela Jurisdicional, consubstanciados na realização da justiça e na pacificação social.

2. A Lei $\mathrm{n}^{\circ}$ 9.50697, ao extinguir o IPC e disciplinar o ressarcimento das verbas a ele recolhidas a título de contribuição dos segurados, omitiu-se quanto à situação do ex-segurados não detentores do direito à pensão.

3. Consumada a extinção do IPC, a exclusão dos ex-segurados do círculo de abrangência da norma garantidora do direito ao resgate configura hipótese clara de locupletamento ilícito por parte da União.

4. Recurso especial provido. (Resp. $n^{\circ}$ 427223/DF. Rel. Min. João Otávio de Noronha. DJU. 20.10.2003).

Nesse sentido, também manifestou-se a C. Primeira Turma deste Sodalício:

\section{DIREITO PREVIDENCIÁRIO. INSTITUTO DE PREVIDÊNCIA DOS CONGRESSISTAS - IPC. EXTINÇÃO. SEGURADO. DESLIGAMENTO. DEVOLUÇÃO DE CONTRIBUIÇÕES PAGAS. DIREITO DOS ANTIGOS E ATUAIS PARLAMENTARES. PRECEDENTE.}

1. "A Lei $n^{\circ} 9.50697$, ao extinguir o IPC e disciplinar o ressarcimento das verbas a ele recolhidas a título de contribuição dos segurados, omitiu-se quanto à situação do ex-segurados não detentores do direito à pensão. Consumada a extinção do IPC, a exclusão dos ex-segurados do círculo de abrangência da norma garantidora do direito ao resgate configura hipótese clara de locupletamento ilícito por parte da União" (REsp n ${ }^{\circ}$ 427223/DF, 2 ${ }^{\text {a }}$ Turma, DJ de 20/10/2003, Rel. Min. João Otávio de Noronha)

2. Há de se reconhecer o direito à restituição de contribuições pagas ao extinto Instituto de Previdência dos Congressistas - IPC, fundo fechado de previdência, visto que os segurados, ex-contribuintes, após a extinção, nenhum benefício receberão em contrapartida, evitando-se, assim, o enriquecimento ilícito da União, sucessora nos direitos e obrigações do IPC.

3. Precedente da egrégia $2^{\mathrm{a}}$ Turma desta Corte.

4. Recurso provido. (Resp. $\mathrm{n}^{\circ}$ 638514DF. Rel. Min. JOSÉ DELGADO. DJU: 16.08.2004). 
$\mathrm{Na}$ ocasião do voto inaugural proferido e firmado pela E. Segunda Turma, o relator adotou os seguintes fundamentos:

"Constatada a omissão legal, cumpre ao Judiciário supri-la, observados, obviamente, os primados jurídicos aplicáveis e tendo sempre em mira o viés social e político da Tutela Jurisdicional, consubstanciados na realização da justiça e na pacificação social.

A propósito, leciona o mestre Canotilho que "o direito não é apenas o 'conteúdo' de regras jurídicas concretas, é também formado constitutivamente por princípios jurídicos abertos como justiça, imparcialidade, igualdade, liberdade. A mediação judicial concretizadora destes princípios é uma tarefa indeclinável dos juízes" (in "Direito Constitucional", Ed. Almedina, 1993, p. 199). Fixada a premissa, tem-se que o cerne da controvérsia está adstrito à verificação do direito da excongressista, ora recorrente, em se ver ressarcida das contribuições efetuadas para o Instituto de Previdência do Congresso, durante os 4 anos em que exerceu o mandato de deputada federal.

Não há, propriamente, uma discriminação legal no tratamento dispensado aos atuais e ex-segurados do IPC, na medida em que a Lei $n^{\circ}$ 9.50697, ao disciplinar o ressarcimento das contribuições, teria apenas se omitido quanto aos segundos. A ilegal discriminação resulta, isto sim, da equivocada interpretação dada ao referido dispositivo pelo Tribunal a quo que, sem penetrar na essência do direito ali resguardado, preferiu pautar sua exegese em critérios de menor relevância, atinentes à condição do segurado ao tempo do resgate.

Com efeito, não pretende a recorrente assegurar qualquer direito à pensão, tampouco obter para si nada além daquilo que foi expressamente garantido aos atuais segurados, em particular àqueles que, em idêntica situação, não completaram o prazo de carência de 8 anos para fazer jus ao benefício previdenciário.

Ademais, o acórdão recorrido deixou de considerar que, com a extinção do Instituto, todos os congressistas foram alçados à condição de exsegurados, não havendo, também sob tal perspectiva, justificativa plausível para se distinguir o ressarcimento.

De outro lado, ainda que se argumente que o art. 25 , caput, da Lei ${ }^{\circ}$ 7.087/82 proíbe a restituição das contribuições efetuadas por exsegurados, é certo que também lhes assegura o direito de reinscrição no IPC para que possam completar o prazo de carência necessário ao gozo da pensão. Inviabilizada, portanto, a possibilidade de reinscrição em face da extinção definitiva do fundo, nada mais correto do que autorizá-los a efetuar o resgate de suas respectivas contribuições.

Por fim, não se pode negar que, consumada a extinção do IPC, a exclusão dos ex-segurados do círculo de abrangência da norma garantidora do direito ao resgate configura, sem dúvida alguma, hipótese clara de locupletamento ilícito por parte da União, sendo de todo oportuno reiterar aqui a bela argumentação desenvolvida pelo culto magistrado de primeiro grau, vazada nos seguintes termos, in verbis:

"No caso em exame, com a extinção do IPC, os contribuintes obrigatórios do referido Instituto tiveram reconhecido seu direito ao ressarcimento das contribuições recolhidas. Tal preceito decorreu, sem sombra de dúvidas, da perspectiva do não locupletamento ilícito por parte do Estado. Logo, se a Lei ${ }^{\circ}$ 9.50697, diferentemente da teleologia justificadora da norma, 
deu tratamento desigual àqueles que substancialmente não são desiguais (atuais congressistas e ex-congressistas, todos contribuintes obrigatórios do Sistema), houve, na espécie, violação ao princípio da isonomia e manifesto locupletamento ilícito, em relação às contribuições dos excongressistas. Tal conclusão é óbvia, cristalina!

Ademais, não serve como alicerce legítimo, à atuação do legislador e da Administração o argumento de que o contribuinte não participa do Sistema Previdenciário apenas em seu favor, mas sim para toda a comunidade envolvida, considerando os princípios da generalidade e da universalidade. Ora, se realmente prevalecesse tal tese, os atuais congressistas, que não cumpriram também período de carência, não teriam direito ao aludido ressarcimento, o que evidencia, mais uma vez, que os fundamentos fático-jurídicos da contestação apresentada são, data venia, falaciosos" (f. 60).

E mais adiante:

"Na ausência de disposição expressa, a autoridade competente para aplicar a legislação tributária utilizará sucessivamente, na ordem indicada

I - a analogia;

II - os princípios gerais de direito tributário;

III - os princípios gerais de direito público;

$I V$ - a equidade.

$\S \S 1^{o}$ e $2^{\circ}(\ldots)$.

Ao tecer comentários à interpretação e à integração da lei no direito tributário, Luciano Amaro aduz que:

"nem sempre se poderá preferir este ou aquele dos instrumentos de integração arrolados, pois situações há em que mais de um deles merece ser invocado. A analogia pode, por exemplo, ser o instrumento necessário a que se dê efetividade a um princípio (p. ex. o da isonomia)" (In. Direito Tributário Brasileiro. São Paulo: Saraiva, 2004, p. 207).

É princípio basilar de direito público a isonomia, mercê cláusula pétrea, admitindo-se na omissão da lei a analogia e a eqüidade.

Segundo doutrina de Ricardo Lobo Torres:

"A interpretação da Constituição e da lei ordinária se aproxima, sob um primeiro ponto de vista, na medida em que a lei ordinária, sendo ela própria fruto do programa constitucional ou da atualização da Constituição, não pode ficar à margem do processo de compreensão desta.

Aproximam-se, por outro lado, porque via de regra não se interpretam as normas abstratas da Constituição, mas as normas das leis ordinárias em 
confronto com as constitucionais. Em outras palavras, controla-se a constitucionalidade da lei ordinária, e não a da própria Constituição.(...) Assim, o princípio da igualdade, de estatura constitucional, influencia toda a interpretação das leis ordinárias, muito especialmente o Direito Tributário" . (grifei). (In, Normas de Interpretação e Integração do Direito Tributário. $3^{a}$ Ed. Rio de Janeiro, Renovar, 2000, p. 233/234).

À luz desses cânones, revela-se injusta a interpretação literal dada à norma indigitada do art. $1^{o}$, $\$ 5^{o}$, da Lei $n$. 9.506/97, porquanto discrimina ex-congressistas em situações idênticas.

Isto porque os ex-contribuintes obrigatórios que exerceram mandado no período entre 1995-1998, ainda que não tenham completado o tempo de carência, fizeram jus à restituição da contribuição, nos termos do inciso I, do art. $1^{o}$, $\$ 5^{\circ}$, da Lei $n^{\circ}$ 9.506/97.

Não poderia, pois, o contribuinte, em situação idêntica, mas que exerceu seu mandado entre o período de 1991/94, ser excluído da restituição dos valores de contribuição.

Nesse sentido, merecem aplausos as lições de Celso Antônio Bandeira de Mello ao discorrer sobre isonomia e ofator tempo, verbis:

"Em conclusão: tempo, só por só, é elemento neutro, condição do pensamento humano e por sua neutralidade absoluta, a dizer, porque em nada diferencia os seres ou situações, jamais pode ser tomado como fator em que se assenta algum tratamento jurídico desuniforme, sob pena de violência à regra da isonomia. Já os fatos ou situações que nele transcorreram e por ele se demarcam, estes sim, é que são e podem ser erigidos em fatores de discriminação, desde que, sobre diferirem entre si, haja correlação lógica entre o acontecimento, cronologicamente demarcado, e a disparidade de tratamento que em função disto se adota.

Sintetizando: aquilo que é, em absoluto rigor lógico, necessária e irregragavelmente igual para todos não pode ser tomado como fator de diferenciação, pena de hostilizar o princípio isonômico. Diversamente, aquilo que é diferenciável, que é, por algum traço ou aspecto, desigual, pode ser diferençado, fazendo-se remissão à existência ou à sucessão daquilo que dessemelhou as situações.

Como a existência ou a sucessão de fatos só ocorre no tempo, a remissão a ele - com fixação de período, prazo, data - é inexorável. Mas daí não resulta que se haja emprestado ao tempo, em si mesmo, um valor de critério distintivo. Resulta, apenas, que este serviu - e não tinha como logicamente deixar de comparecer - como referência dos fatos ou sucessão de fatos tomados em conta, por si mesmos, no que possuíam de deferençados.

Tanto isto é verdade que não há como se conceber qualquer regulamentação normativa isenta de referência temporal, o que, aliás, serve para demonstrar sua absoluta neutralidade. Deveras: ou a lei fixa um tempo dado ao regular certa situação ou, inversamente, não fixa qualquer limite. Em ambos os casos há uma referência temporal. Numa é demarcada, noutra é ilimitada, mas ambos levam em conta o tempo, seja medido, seja continuado indefinidamente. Pois, o tempo medido é tão-só uma referência a uma quantidade determinada de fatos e situações que 
nele tiveram ou terão lugar, ao passo que o tempo ilimitado é também referência a uma quantidade de fatos e situações por definição indeterminados.

O que se põe em pauta, nuclearmente, portanto, são sempre pessoas, fatos ou situações, pois só neles podem residir diferenças. Uma destas diferenças é a reiteração maior ou menor. É a sucessão mais dilatada ou menos dilatada; é, em suma, a variação da persistência. Esta variação demarca-se por um período, por uma data, mas o que está sendo objeto de demarcação não é, obviamente, nem o período em abstrato nem a data em abstrato, mas os próprios fatos ou situações contemplados $e$ demarcados.

Isto posto, procede concluir: a lei não pode tomar tempo ou data como fator de discriminação entre pessoas a fim de lhes dar tratamentos díspares, sem com isto pelejar à arca partida com o princípio da igualdade. $O$ que pode tomar como elemento discriminador é o fato, é o acontecimento, transcorrido em certo tempo por ele determinado.

Nem poderia ser de outro modo, pois as diferenças de tratamento só se justificam perante fatos e situações diferentes. Ora, o tempo não está nos fatos ou acontecimentos: logo, sob este ângulo, fatos e acontecimentos em nada se diferenciam. Deveras: são os fatos e acontecimentos que estão alojados no tempo e não o inverso.

A distinção feita longe está de ser acadêmica e nem se procedeu a ela por amor a algum preciosismo cerebrino. Pelo contrário, apresenta-se sobremaneira fértil em repercussões práticas.

Com efeito, sendo procedente a distinção, ao se examinar algum discrimen legal, para fins de buscar-lhe afinamento ou desafinamento com o preceito isonômico, o que se tem de perquirir é se os fatos ou situações alojadas no tempo transcrito são, eles mesmos, distintos, ao invés de se indagar pura e simplesmente se transcorreram em momentos passados diferentes.

Se são iguais, não há como diferençá-los, sem desatender à cláusula da isonomia. Portanto, se a lei confere benefício a alguns que exerceram tais ou quais cargos, funções, atos, comportamentos, em passado próximo e nega aos que exerceram em passado mais remoto (ou viceversa) estará delirando do preceito isonômico, a menos que existam, nos próprios atos ou fatos, elementos, circunstâncias, aspectos relevantes em si mesmos, que os hajam tornado distintos quando sucedidos em momentos diferentes.

Com efeito: o que autoriza discriminar é a diferença que as coisas possuam em si e a correlação entre o tratamento desequiparador e os dados diferenciais radicados nas coisas.

As coisas é que residem no tempo. O tempo não se aloja nos fatos ou pessoas. Portanto o tempo não é uma diferença que neles assiste. Deste ponto de vista, pessoas, fatos e situações são iguais. Por isso se disse que o tempo é neutro. Se o tempo não é uma inerência, uma qualidade, um atributo próprio das coisas (pois são elas que estão no tempo e não o tempo nelas) resulta que em nada diferem pelo só fato de ocorrerem em ocasiões já ultrapassadas. Todas existiram. E se existiram do mesmo modo, sob igual feição, então, são iguais e devem receber tratamento paritário. 
Afinal: há de ser nos próprios acontecimentos tomados em conta que se buscarão diferenças justificadoras de direitos e deveres distintos e não em fatores alheios a eles que em nada lhes agregam peculiaridades desuniformizadoras". (In, Conteúdo Jurídico do Princípio da Igualdade. $3^{a}$ Ed. 14a Tiragem. São Paulo, Malheiros, 2006, p. 32/34).

Deveras, com a extinção do IPC, o direito dos contribuintes ao ressarcimento das contribuições recolhidas visou precipuamente o princípio básico do direito previdenciário da contra-prestação, evitando o enriquecimento sem causa do fundo.

Mister esclarecer, finalmente, que o prazo preclusivo de 06 (seis) meses, para habilitação, contido no art. 24, § único, da lei $n^{\circ}$ 9.506/97, não se aplicava ao ex-contribuinte obrigatório que viesse a ser reinscrito na mesma categoria, porquanto teria seu tempo de contribuição contado para todos os efeitos legais. Com efeito, a extinção do IPC impossibilitou $o$ ex-contribuinte obrigatório de retornar a contribuir e completar o tempo de carência, verbis:

Art. 24 - O segurado obrigatório que, ao término do exercício do mandato, não haja cumprido o período de 8 (oito) anos, consecutivos ou alternados, e o segurado facultativo que se desligar do órgão ao qual pertença, poderão continuar contribuindo mensalmente, com as partes correspondentes ao segurado e ao órgão, ate completar o período de carência ou a idade estabelecida no art. 34 desta Lei, devendo estas contribuições integrais receber os reajustes proporcionais à majoração do valor-base de cálculo.

Parágrafo único - O prazo para habilitação à continuidade da contribuição de carência é de 6 (seis) meses, improrrogável, a contar do dia imediato ao fim do mandato ou exercício de mandato ou do dia do desligamento.

Art. 25 - Ao segurado que desistir de pagar o restante da carência, que cancelar ou tiver cancelada sua inscrição, não serão restituídas as contribuições já feitas, podendo, no entanto, reinscrever-se no IPC.

$\S 1^{\circ}$ - Os que se tornarem segurados mediante reinscrição, inclusive os pensionistas serão considerados para todos os efeitos legais, como se inscritos pela primeira vez no IPC.

$\S 2^{\circ}$ - $O$ disposto no parágrafo anterior não se aplica aos antigos segurados obrigatórios que venham a ser reinscritos na mesma categoria, que terão as contribuições anteriores consideradas para todos os efeitos legais, desde que satisfeitas as exigências constantes do art. 26 desta Lei. 


\subsection{2. $O$ contraste à luz do princípio}

O caso é bastante interessante, porque discute a diferença de interpretação de determinada lei se não analisada à luz de um princípio constitucional. Como já falamos, a fixação do princípio constitucional como premissa maior permite o desdobramento de juízos que estão virtualizados, o que possibilita ao juiz ir além da lei, ao fixar uma interpretação extensiva da legislação, captando as necessidades de mudança do Direito em sociedades em transformação como a nossa, mas se mantendo dentro dos limites do ordenamento jurídico. Como anota Gustavo Zagrebelsky, ${ }^{186}$ enquanto as regras nos proporcionam critérios específicos sobre como devemos, não devemos ou podemos atuar em determinadas situações, os princípios nos proporcionam critérios para tomar uma posição diante de situações concretas que, no entanto, a priori, são indeterminadas, só adquirindo significado operativo no momento de sua aplicação a um caso concreto, pois a elas não se pode atribuir uma determinação em abstrato. Nesta tomada de posição os princípios são, como diria Alexy, mandados de otimização dos valores consagrados. ${ }^{187}$

O caso revela com bastante nitidez a diferença de raciocínio desenvolvido pelo relator do recurso especial em relação àquele desenvolvido pelo juiz de primeiro grau e pelos membros do Tribunal Regional da $1^{\mathrm{a}}$ Região.

A fixação do raciocínio de forma ordenada, a iniciar pelos princípios gerais, passando pelos princípios específicos e depois pelas normas infraconstitucionais alterou a conclusão final.

Fixado o princípio da isonomia como valor a ser assegurado, todo o raciocínio desenvolvido passou a ser decorrente dele, o que não ocorreu nas decisões anteriores, acerca do mesmo caso concreto, quando o referido princípio não foi sequer considerado.

\footnotetext{
"Sob esse ângulo, assume relevo a localização da matéria constitucional no afã de aferir a que vetor principiológico pertence, para que, observando o princípio maior, a partir dele, transitar pelos princípios específicos, até o alcance da norma infraconstitucional.

Consectariamente, a exegese da legislação infraconstitucional deve, sempre que possível, curvar-se à força normativa da Carta Maior."
}

\footnotetext{
${ }^{186}$ ZAGREBELSKY, op. cit., p. 110-111 (Cf. LAFER, Celso. A Constituição de 1988 e as relações internacionais: reflexões sobre o art. $4^{\circ}$, cit.).

${ }^{187}$ LAFER, Celso. A Constituição de 1988 e as relações internacionais: reflexões sobre o art. $4^{\text {o }}$, cit., p. 11.

(Cf. ALEXY, Robert. A theory of constitucional rights, cit.).
} 


\begin{abstract}
"A interpretação da Constituição e da lei ordinária se aproxima, sob um primeiro ponto de vista, na medida em que a lei ordinária, sendo ela própria fruto do programa constitucional ou da atualização da Constituição, não pode ficar à margem do processo de compreensão desta.

Aproximam-se, por outro lado, porque via de regra não se interpretam as normas abstratas da Constituição, mas as normas das leis ordinárias em confronto com as constitucionais. Em outras palavras, controla-se a constitucionalidade da lei ordinária, e não a da própria Constituição.(...) Assim, o princípio da igualdade, de estatura constitucional, influencia toda a interpretação das leis ordinárias, muito especialmente o Direito Tributário"
\end{abstract}

Diante da normatividade da Constituição, de sua vocação à eficácia e do necessário respeito que há de merecer, não resta mais espaço legítimo, para atender a conveniências ditadas pela conjuntura, pela realidade dos fatos presentes, por vezes suscetíveis de rápida mutação, ou de parâmetros concebidos na antevisão de planos de ação político-administrativa, se não estiverem em conformidade com a Constituição. Podemos dizer que "todos os interesses momentâneos -ainda quando realizados - não logram compensar o incalculável ganho resultante do comprovado respeito à Constituição, sobretudo naquelas situações em que sua observância revela-se incômoda."188

Destarte, é preciso respeitar de modo incondicional os princípios consagrados na Constituição, valores aceitos pela sociedade, a fim de que a interpretação judicial seja legítima e encontre aceitação, dissimulando, com isso, a violência simbólica que representa.

Cumpre registrar que o fato de a atividade do juiz não ser unicamente lógica, mas também valorativa e eticamente orientada, "não modifica a circunstância de que suas valorações chegam a ser direito não pelo fato de serem boas, sábias, justas, conformes ao direito natural, mas simplesmente porque elas se convertem em regras válidas do sistema" 189

\footnotetext{
${ }^{188}$ FANTONI JÚNIOR, Neyton. op. cit., p. 852.

${ }^{189}$ BARBOSA, Alaor. Norberto Bobbio e o positivismo jurídico. Revista de Informação Legislativa, Brasília, ano 25, n. 97, p. 288, jan./mar. 1988.
} 


\subsection{A função criativa do juiz (REsp 753.565/MS)}

Trata-se de ação civil pública proposta pelo Ministério Público do Estado de Mato Grosso do Sul, com objetivo de garantir a matrícula de todas as crianças com seis anos incompletos, no primeiro ano do ensino fundamental da rede municipal e estadual de ensino, desde que comprovada sua capacidade, pedido que restou deferido pelo juízo de primeiro grau, nos seguintes termos:

"Para privar o acesso ao ensino fundamental, o Estado ou Municípios
devem provar, então, que a criança não possui capacidade para iniciar o
seu aprendizado, isto de forma individual, não genérica, porque a
capacidade de cada um, prevista constitucionalmente como garantia à
educação, bem assim na LDB e no ECA, não se afere única e
exclusivamente pela idade cronológica. Com isso, não é difícil concluir que uma criança prematuramente capaz possa ingressar no ensino fundamental antes de cinco, seis ou sete anos, porque a sua capacidade lhe assegura o direito à educação, e tal circunstância não estaria a burlar qualquer legislação (...)

Ante o exposto, e considerando o mais que dos autos constam, julga-se procedente a presente ação civil pública para, em confirmando liminar concedida anteriormente, determinar ao Estado de Mato Grosso do Sul e Municípios de Ivinhema e Novo Horizonte do Sul que matriculem e mantenham matriculados no ensino fundamental as crianças menores de seis anos que comprovarem, através de submissão à avaliação da equipe nomeada pelo juízo, terem a capacidade para o início dos estudos, fincando declarada a extinção do feito pelo julgamento do mérito, ex vi do art. 269, I, do Código de Processo Civil.(...)"

Irresignado o Estado do Mato Grosso do Sul manejou apelação, alegando preliminarmente, consoante artigo 267, VI, do Código de Processo Civil, carência de ação, por não possuir o Parquet estadual uma das condições para o válido e normal desenvolvimento do feito, tendo em vista que a ação civil pública, via eleita para a obtenção do fim almejado, não se presta para a declaração de inconstitucionalidade de ato normativo, e no mérito, aduziu que o ato de indeferimento da matrícula das crianças não representou ou representa nenhuma ilegalidade ou arbitrariedade.

O Tribunal de Justiça do Estado do Mato Grosso do Sul rejeitou a preliminar e, no mérito, negou provimento à apelação, por meio do voto-vista do revisor, fundado nas seguintes razões: 


\begin{abstract}
"A questão central, objeto do presente recurso e reexame necessário, cinge-se em saber se o ato de indeferimento de matrícula de crianças com idade inferior a seis anos de idade, representa ilegalidade ou inconstitucionalidade, em face da legislação pátria.

Em que pese o respeito que devoto ao eminente relator, ouso dele discordar, no caso, pois não há que se falar em legalidade ou constitucionalidade de restrição à matrícula de crianças no ensino fundamental, desde que sejam elas submetidas à avaliação pedagógica.
\end{abstract}

Ora, em que pese a Lei de Diretrizes e Bases da Educação Nacional prever, em seu art. $87, \S 3^{\circ}$, inciso I, que a matrícula no ensino fundamental está condicionada a que a criança tenha 7 (sete) anos de idade, ou facultativamente, a partir dos seis anos, a Constituição Federal, em seu art. 208, inciso V, dispõe que o acesso aos diversos níveis de educação depende da capacidade de cada um, sem explicitar qualquer critério restritivo, relativo a idade.

O dispositivo constitucional acima mencionado, está ínsito no art. 54, inciso V, do Estatuto da Criança e do Adolescente, sendo dever do Estado assegurar à criança e ao adolescente o acesso à educação, considerada direito fundamental.

Destarte, havendo nos autos (fls. 88 a 296), comprovação de capacidade das crianças residentes em Ivinhema e Novo Horizonte do Sul, através de laudos de avaliação psicopedagógica, considerando-as aptas para serem matriculadas no ensino infantil e fundamental, tenho que dever ser-lhes assegurado o direito constitucional à educação (...)" (grifou-se)

Irresignado, o Estado do Mato Grosso do Sul interpôs recurso especial, ao argumento de que o acórdão do Tribunal de origem violara os artigos $8^{\circ}, \S 2^{\circ} ; 11, \mathrm{~V} ; 24$ e 87, § $3^{\circ}$, todos da Lei 9.39496 (Lei de Diretrizes e Bases da Educação Nacional), por lesionar gravemente a ordem pública, na medida em que inverte por completo o sistema constitucional e legal, afrontando competências precípuas e privativas dos Poderes Executivos e Legislativos, motivo pelo qual requer a observância das Resoluções SED n ${ }^{\circ}$ 1452, de dezembro de 2000 e SEMEEC nº 01, de 11 de janeiro de 2002, que não permitem o ingresso indiscriminado de menores de 06 (seis) anos no ensino fundamental.

Aduziu que a própria Lei de Diretrizes e Bases da Educação Nacional traz uma exceção quanto à idade mínima para ingresso no ensino fundamental. Argumentou, ainda, que a decisão invadiu competência legislativa ao autorizar que crianças de cinco anos de idade sejam matriculadas na $1^{\mathrm{a}}$ série do ensino fundamental, dispensando a exigência de regularização da guarda de fato para a efetivação da matrícula, por destoar do teor da Lei de Diretrizes e Bases da Educação Nacional. Ao ampliar a abrangência da norma legal gerou-se precedente que criará o "caos na educação pública, visto que, em 
muitos municípios não existem vagas nas escolas", salientando ainda que a rede pública "não oferece salas com adaptação física para uma criança de 5 anos de idade".

Afirmou que "há perigo à saúde das crianças abrangidas pela medida, pois olvidou-se da necessidade de trabalho pedagógico e de avaliação adequados para aferir a capacidade psíquica" das mesmas.

Ademais salientou que "as crianças com tão pouca idade teriam que realizar periodicamente avaliações e cumprir tarefas, ficando assim limitado o tempo disponível para recreações, o que refletiria negativamente em seu comportamento.

Por fim, sustentou grave lesão à economia pública "pois o Estado terá que alocar recursos compatíveis com o aumento de alunos, decorrente do ingresso de crianças com cinco anos no ensino fundamental, que exige tratamento especializado."

O Estado do Mato Grosso do Sul também manejou recurso extraordinário; o Ministério Público Estadual apresentou contra-razões.

Realizado o juízo negativo de admissibilidade do recurso especial, o Estado do Mato Grosso interpôs agravo de instrumento em desfavor da supracitada decisão, o qual restou provido ensejando à apreciação do Recurso Especial.

Todavia, o Recurso especial não foi conhecido. Eis a ementa do acórdão.

$$
\text { RECURSO ESPECIAL No } 753.565 \text { - MS (2005/0086585-2) }
$$

ADMINISTRATIVO. CONSTITUCIONAL. ART. 127 DA CF/88. ART. 7. DA LEI N. ${ }^{\circ} 8.069990$. DIREITO AO ENSINO FUNDAMENTAL AOS MENORES DE SEIS ANOS "INCOMPLETOS". NORMA CONSTITUCIONAL REPRODUZIDA NO ART. 54 DO ESTATUTO DA CRIANÇA E DO ADOLESCENTE. NORMA DEFINIDORA DE DIREITOS NÃO PROGRAMÁTICA. EXIGIBILIDADE EM JUÍZO. INTERESSE TRANSINDIVIDUAL ATINENTE ÀS CRIANÇAS SITUADAS NESSA FAIXA ETÁRIA. CABIMENTO E PROCEDÊNCIA.

1. O direito à educação, insculpido na Constituição Federal e no Estatuto da Criança e do Adolescente, é direito indisponível, em função do bem comum, maior a proteger, derivado da própria força impositiva dos preceitos de ordem pública que regulam a matéria.

2. O direito constitucional ao ensino fundamental aos menores de seis anos incompletos é consagrado em norma constitucional reproduzida no art. 54 do Estatuto da Criança e do Adolescente (Lei n. ${ }^{\circ}$ 8.069/90):

"Art. 54. É dever do Estado assegurar à criança e ao adolescente: (...) V acesso aos níveis mais elevados do ensino, da pesquisa e da criação artística, segundo a capacidade de cada um; (omissis)" 
3. In casu, como anotado no aresto recorrido "a Lei de Diretrizes e Bases da Educação Nacional prever, em seu art. 87, § $3^{\circ}$, inciso I, que a matrícula no ensino fundamental está condicionada a que a criança tenha 7 (sete) anos de idade, ou facultativamente, a partir dos seis anos, a Constituição Federal, em seu art. 208, inciso V, dispõe que o acesso aos diversos níveis de educação depende da capacidade de cada um, sem explicitar qualquer critério restritivo, relativo a idade. $\mathrm{O}$ dispositivo constitucional acima mencionado, está ínsito no art. 54, inciso V, do Estatuto da Criança e do Adolescente, sendo dever do Estado assegurar à criança e ao adolescente o acesso à educação, considerada direito fundamental. Destarte, havendo nos autos (fls. 88 a 296), comprovação de capacidade das crianças residentes em Ivinhema e Novo Horizonte do Sul, através de laudos de avaliação psicopedagógica, considerando-as aptas para serem matriculadas no ensino infantil e fundamental, tenho que dever ser-lhes assegurado o direito constitucional à educação (...)"

4. Conclui-se, assim, que o decisum impugnado assegurou um dos consectários do direito à educação, fundado nas provas, concluindo que a capacidade de aprendizagem da criança deve ser analisada de forma individual, não genérica, porque tal condição não se afere única e exclusivamente pela idade cronológica, o que conduz ao não conhecimento do recurso nos termos da Súmula 7 do STJ, verbis: "A pretensão de simples reexame de prova não enseja Recurso Especial".

5. Releva notar que uma Constituição Federal é fruto da vontade política nacional, erigida mediante consulta das expectativas e das possibilidades do que se vai consagrar, por isso que cogentes e eficazes suas promessas, sob pena de restarem vãs e frias enquanto letras mortas no papel. Ressoa inconcebível que direitos consagrados em normas menores como Circulares, Portarias, Medidas Provisórias, Leis Ordinárias tenham eficácia imediata e os direitos consagrados constitucionalmente, inspirados nos mais altos valores éticos e morais da nação sejam relegados a segundo plano. Prometendo o Estado o direito à creche, cumpre adimpli-lo, porquanto a vontade política e constitucional, para utilizarmos a expressão de Konrad Hesse, foi no sentido da erradicação da miséria intelectual que assola o país. O direito à creche é consagrado em regra com normatividade mais do que suficiente, porquanto se define pelo dever, indicando o sujeito passivo, in casu, o Estado.

6. Consagrado por um lado o dever do Estado, revela-se, pelo outro ângulo, o direito subjetivo da criança. Consectariamente, em função do princípio da inafastabilidade da jurisdição consagrado constitucionalmente, a todo direito corresponde uma ação que o assegura, sendo certo que todas as crianças nas condições estipuladas pela lei encartam-se na esfera desse direito e podem exigi-lo em juízo. A homogeneidade e transindividualidade do direito em foco enseja a propositura da ação civil pública.

7. A determinação judicial desse dever pelo Estado, não encerra suposta ingerência do judiciário na esfera da administração. Deveras, não há discricionariedade do administrador frente aos direitos consagrados, quiçá constitucionalmente. Nesse campo a atividade é vinculada sem admissão de qualquer exegese que vise afastar a garantia pétrea.

8. Um país cujo preâmbulo constitucional promete a disseminação das desigualdades e a proteção à dignidade humana, alçadas ao mesmo patamar da defesa da Federação e da República, não pode relegar o 
direito à educação das crianças a um plano diverso daquele que o coloca, como uma das mais belas e justas garantias constitucionais.

9. Afastada a tese descabida da discricionariedade, a única dúvida que se poderia suscitar resvalaria na natureza da norma ora sob enfoque, se programática ou definidora de direitos. Muito embora a matéria seja, somente nesse particular, constitucional, porém sem importância revelase essa categorização, tendo em vista a explicitude do ECA, inequívoca se revela a normatividade suficiente à promessa constitucional, a ensejar a acionabilidade do direito consagrado no preceito educacional.

10. As meras diretrizes traçadas pelas políticas públicas não são ainda direitos senão promessas de lege ferenda, encartando-se na esfera insindicável pelo Poder Judiciário, qual a da oportunidade de sua implementação.

11. Diversa é a hipótese segundo a qual a Constituição Federal consagra um direito e a norma infraconstitucional o explicita, impondo-se ao judiciário torná-lo realidade, ainda que para isso, resulte obrigação de fazer, com repercussão na esfera orçamentária.

12. Ressoa evidente que toda imposição jurisdicional à Fazenda Pública implica em dispêndio e atuar, sem que isso infrinja a harmonia dos poderes, porquanto no regime democrático e no estado de direito o Estado soberano submete-se à própria justiça que instituiu. Afastada, assim, a ingerência entre os poderes, o judiciário, alegado o malferimento da lei, nada mais fez do que cumpri-la ao determinar a realização prática da promessa constitucional.

13. Ad argumentandum tantum, o direito do menor à freqüência de escola, insta o Estado a desincumbir-se do mesmo através da sua rede própria. Deveras, matricular um menor de seis anos no início do ano e deixar de fazê-lo com relação aquele que completaria a referida idade em um mês, por exemplo, significa o mesmo que tentar legalizar a mais violenta afronta ao princípio da isonomia, pilar não só da sociedade democrática anunciada pela Carta Magna, mercê de ferir de morte a cláusula de defesa da dignidade humana.

14. O Estado não tem o dever de inserir a criança numa escola particular, porquanto as relações privadas subsumem-se a burocracias sequer previstas na Constituição. O que o Estado soberano promete por si ou por seus delegatários é cumprir o dever de educação mediante o oferecimento de creche para crianças de zero a seis anos. Visando ao cumprimento de seus desígnios, o Estado tem domínio iminente sobre bens, podendo valer-se da propriedade privada, etc. O que não ressoa lícito é repassar o seu encargo para o particular, quer incluindo o menor numa 'fila de espera', quer sugerindo uma medida que tangencia a legalidade, porquanto a inserção numa creche particular somente poderia ser realizada sob o pálio da licitação ou delegação legalizada, acaso a entidade fosse uma longa manu do Estado ou anuísse, voluntariamente, fazer-lhe as vezes. Precedente jurisprudencial do STJ: RESP 575.280SP, desta relatoria $\mathrm{p}$ acórdão, publicado no DJ de 25.10.2004.

15. O Supremo Tribunal Federal, no exame de hipótese análoga, nos autos do RE 436.996-6SP, Relator Ministro Celso de Mello, publicado no DJ de 07.11.2005, decidiu verbis: 
"CRIANÇA DE ATÉ SEIS ANOS DE IDADE. ATENDIMENTO EM CRECHE E EM PRÉ-ESCOLA. EDUCAÇÃO INFANTIL. DIREITO ASSEGURADO PELO PRÓPRIO TEXTO CONSTITUCIONAL (CF, ART. 208, IV). COMPREENSÃO GLOBAL DO DIREITO CONSTITUCIONAL À EDUCAÇÃO. DEVER JURÍDICO CUJA EXECUÇÃO SE IMPÕE AO PODER PÚBLICO, NOTADAMENTE AO MUNICÍPIO(CF, ART. 211, § $2^{\circ}$ ). RECURSO EXTRAORDINÁRIO CONHECIDO E PROVIDO.

- A educação infantil representa prerrogativa constitucional indisponível, que, deferida às crianças, a estas assegura, para efeito de seu desenvolvimento integral, e como primeira etapa do processo de educação básica, o atendimento em creche e o acesso à pré-escola $(\mathrm{CF}$, art. 208, IV).

- Essa prerrogativa jurídica, em consequiência, impõe, ao Estado, por efeito da alta significação social de que se reveste a educação infantil, a obrigação constitucional de criar condições objetivas que possibilitem, de maneira concreta, em favor das "crianças de zero a seis anos de idade" (CF, art. 208, IV), o efetivo acesso e atendimento em creches e unidades de pré-escola, sob pena de configurar-se inaceitável omissão governamental, apta a frustrar, injustamente, por inércia, o integral adimplemento, pelo Poder Público, de prestação estatal que lhe impôs o próprio texto da Constituição Federal.

- A educação infantil, por qualificar-se como direito fundamental de toda criança, não se expõe, em seu processo de concretização, a avaliações meramente discricionárias da Administração Pública, nem se subordina a razões de puro pragmatismo governamental.

- Os Municípios - que atuarão, prioritariamente, no ensino fundamental e na educação infantil $\left(\mathrm{CF}\right.$, art. $\left.211, \S 2^{\circ}\right)$ - não poderão demitir-se do mandato constitucional, juridicamente vinculante, que lhes foi outorgado pelo art. 208, IV, da Lei Fundamental da República, e que representa fator de limitação da discricionariedade político--administrativa dos entes municipais, cujas opções, tratando-se do atendimento das crianças em creche (CF, art. 208, IV), não podem ser exercidas de modo a comprometer, com apoio em juízo de simples conveniência ou de mera oportunidade, a eficácia desse direito básico de índole social.

- Embora inquestionável que resida, primariamente, nos Poderes Legislativo e Executivo, a prerrogativa de formular e executar políticas públicas, revela-se possível, no entanto, ao Poder Judiciário, ainda que em bases excepcionais, determinar, especialmente nas hipóteses de políticas públicas definidas pela própria Constituição, sejam estas implementadas, sempre que os órgãos estatais competentes, por descumprirem os encargos político-jurídicos que sobre eles incidem em caráter mandatório, vierem a comprometer, com a sua omissão, a eficácia e a integridade de direitos sociais e culturais impregnados de estatura constitucional. A questão pertinente à "reserva do possível". Doutrina.

16. Recurso especial não conhecido.

A questão central debatida nesse recurso especial e reexame necessário, cinge-se em saber se o ato de indeferimento da matrícula de crianças com idade inferior a 
seis anos de idade, representa ilegalidade ou inconstitucionalidade, em face da legislação pátria.

Para efeito de nossos estudos, deixaremos de abordar as questões processuais concernentes ao cabimento ou não do recurso especial em face da Súmula $n^{\circ} 7$ do STJ, verbis: “A pretensão de simples reexame de prova não enseja Recurso Especial.”, passando à análise do mérito da questão debatida no STJ.

Observamos que o relator, Ministro Luiz Fux, iniciou o raciocínio fixando uma premissa: ser o direito à educação, insculpido na Constituição Federal e no Estatuto da Criança e do Adolescente, indisponível, em função do bem comum maior a proteger, derivado da própria força impositiva dos preceitos de ordem pública que regulam a matéria.

O raciocínio do relator pode ser resumido da seguinte maneira: em que pese a Lei de Diretrizes e Bases da Educação Nacional prever, em seu artigo 87, §3º inciso I, que a matrícula no ensino fundamental está condicionada a que a criança tenha sete anos de idade, ou facultativamente, a partir dos seis anos, a Constituição Federal, em seu artigo 208, V, dispõe que o acesso aos diversos níveis de educação depende da capacidade de cada um, sem explicitar qualquer critério restritivo, relativo à idade.

Sabemos que a Constituição Federal é fruto da vontade política de um povo, erigida mediante consultas das expectativas e das possibilidades do que se vai consagrar, por isso cogentes e eficazes as suas promessas, sob pena de restarem vãs e frias enquanto letras mortas no papel. Ressoa inconcebível que direitos consagrados em normas menores como Circulares, Portarias, Medidas Provisórias, Leis Ordinárias tenham eficácia imediata e os direitos consagrados constitucionalmente sejam relegados a segundo plano.

Quando a Constituição consagra um direito e a norma infraconstitucional o explicita, não há discricionariedade no comportamento da Administração Pública. A atividade passa, então, a ser vinculada, inadmitindo-se qualquer exegese que vise a afastar a garantia constitucional.

Embora resida, primariamente, nos Poderes Legislativo e Executivo, a prerrogativa de formular e executar políticas públicas, revela-se, possível, no entanto, ao Poder Judiciário, formular e executar políticas públicas, ainda que em bases excepcionais, especialmente nas hipóteses de políticas públicas definidas pela própria Constituição, sempre que os órgãos estatais competentes, por descumprirem os encargos político- 
jurídicos que sobre eles incidem vierem a comprometer, com a sua omissão, a eficácia e a integridade de direitos sociais e culturais impregnados de estatura constitucional.

É evidente que toda a imposição jurisdicional à Fazenda Pública implica em dispêndio. Todavia, o Brasil, na qualidade de Estado Democrático e de Direito, submete-se à própria justiça que instituiu. Portanto, cabe ao Judiciário concretizar o direito constitucional, ainda que isso resulte em obrigação de fazer, com repercussão na esfera pública.

Se o Estado deixar de adotar as medidas necessárias à realização concreta dos preceitos da Constituição, em ordem a torná-los efetivos, operantes e exequiíveis, abstendo-se de cumprir o dever de prestação que a Constituição lhe impôs, incidirá em violação negativa do texto constitucional. Desse non facere ou non praestare, resultará a inconstitucionalidade por omissão, que pode ser total, quando é nenhuma a providência adotada, ou parcial, quando é insuficiente a medida efetivada pelo Poder Público.

É certo que não se inclui no âmbito das funções institucionais do Poder Judiciário a atribuição de formular e implementar políticas públicas, pois, nesse domínio, o encargo reside, primariamente, nos Poderes Legislativo e Executivo.

No entanto, tal incumbência poderá atribuir-se ao Poder Judiciário, se e quando os órgãos estatais competentes, por descumprirem os encargos político- jurídicos que sobre eles incidirem em caráter mandatório, vierem a comprometer, com tal comportamento, a eficácia e integridade de direitos individuais e coletivos de estatura constitucional.

Não se ignora que a realização dos direitos econômicos, sociais e culturais além de caracterizar-se pela gradualidade de seu processo de concretização, depende, em grande medida, de um inescapável vínculo financeiro subordinado às possibilidades orçamentárias do Estado, de tal modo que comprovada, objetivamente, a alegação da incapacidade econômica-financeira da pessoa estatal, desta não se poderá exigir a imediata efetivação do comando fundado no texto da Carta Política, mas mesmo assim caberá ao Judiciário ser criativo no amparo do direito ameaçado. ${ }^{190}$

\footnotetext{
${ }^{190}$ Nesse sentido, ARENDT, Hannah. Eichmann em Jerusalém: um relato sobre a banalidade do mal, cit., p. 189-190: “A história dos judeus dinamarqueses é sui generis, e o comportamento do povo dinamarquês foi o único entre todos os países da Europa - ocupada, associada ao Eixo, neutra ou verdadeiramente independente. É forte a tentação de recomendar a leitura obrigatória desse episódio da ciência política para todos os estudantes que queiram aprender alguma coisa sobre o enorme potencial de poder inerente à ação não violenta e à resistência a um oponente detentor de meios de violência vastamente superiores [...]. A
} 
Todavia, não se mostra lícito ao Poder Público criar obstáculo artificial que revele - a partir de indevida manipulação de sua atividade financeira e/ou políticoadministrativa - o ilegítimo, arbitrário, e censurável propósito de fraudar, de frustrar e inviabilizar o estabelecimento e a preservação, em favor da pessoa e dos cidadãos, de condições materiais mínimas de existência. ${ }^{191}$

O administrador público está vinculado à Constituição e às normas infraconstitucionais para a implementação de políticas públicas relativas à ordem social e constitucional, ao bem-estar e justiça social, sendo mínima a sua margem de discricionariedade, não contemplando o não fazer.

Desse modo, a cláusula da reserva do possível, ressalvada a ocorrência de justo motivo objetivamente aferível, não pode ser invocada pelo Estado, com a finalidade de exonerar-se, dolosamente, do cumprimento de suas obrigações constitucionais, notadamente quando, dessa conduta governamental negativa, puder resultar nulidificação ou, até mesmo, aniquilação de direitos constitucionais essenciais.

O administrador público não tem discricionariedade para deliberar sobre a oportunidade e conveniência de implementação de políticas públicas discriminadas na ordem social constitucional, pois tal restou deliberado pelo Constituinte e pelo legislador que elaborou as normas de integração.

Dessa leitura, fica claro que o raciocínio do relator, embasado na fundamentação do Ministro Celso de Mello (ADPF 45/DF), foi estabelecido na seguinte ordem: princípios constitucionais gerais, princípios constitucionais específicos e legislação infraconstitucional.

Embora as exigências postas ao Estado Social autorizem o intérprete a qualificar os princípios constitucionais, atribuindo-lhe uma certa discricionariedade hermenêutica por apresentarem certo grau de abstração e incidirem sobre uma pluralidade de situações, isso não lhes retira o caráter deontológico. Os princípios, na qualidade de normas constitucionais, obrigam os seus destinatários sem exceção e incondicionalmente, sob pena de vulnerar-se o princípio da segurança jurídica que é a base e a condição

Itália e a Bulgária sabotavam as ordens alemãs e se permitiam um complicado jogo de negociação e trapaça, salvando os seus judeus graças a tour de force de pura criatividade, mas jamais contestaram a política enquanto tal. Os dinamarqueses fizeram uma coisa completamente diferente. Quando os alemães os abordaram, bastante cautelosamente, quanto à introdução do emblema amarelo, eles simplesmente disseram que o rei seria o primeiro a usá-la, e os funcionários governamentais dinamarqueses tiveram o cuidado de esclarecer que medidas antijudaicas de qualquer ordem provocariam sua imediata renúncia[...]".

${ }^{191}$ Min. Celso de Mello, ADPF 45/DF, Informativo do STF no 345/2004. 
necessária para a viabilização dos objetivos e fundamentos da República Federativa do Brasil, permitindo a estabilidade necessária ao indivíduo e à sociedade.

Nesse sentido, anota Dalmo Dallari que "entre as principais necessidades e aspirações das sociedades humanas encontra-se a segurança jurídica. Não há pessoa, grupo social, entidade pública ou privada que não tenha necessidade de segurança jurídica para atingir seus objetivos e até mesmo sobreviver."192

Destarte, o juiz, ao elaborar a sua decisão, deve curvar-se aos princípios constitucionais, fixando-os como premissa maior, porque o princípio é sempre o começo de um raciocínio que se pretende correto. Se o magistrado não se curva ao princípio, além de raciocinar de forma incorreta, abre espaço para os preconceitos pessoais, os unilateralismos de opinião, a heterogeneidade dos critérios, o espírito sectarista e os palpites pessoais na formação do direito.

O juiz é livre na hora de sentenciar e decidir no sentido da liberdade pública de participação democrática. ${ }^{193}$ Nesse espaço público que lhe é reservado, o juiz deve construir o Direito, ousar hipóteses que representem um sentimento em face da vida, mas sempre se curvando aos princípios constitucionais, porque as suas construções e justificações só chegam a ser de Direito se estiverem previstas no ordenamento jurídico.

\subsection{Premissas equivocadas (ADI 1232)}

Nesse caso analisaremos a decisão prolatada em ação cautelar preparatória de ADI ajuizada pelo Procurador Geral da República contra o Presidente da República e o Congresso Nacional.

O Procurador Geral da República, adotando os argumentos a ele dirigidos pelo Procurador Geral de Justiça, que por sua vez, acolheu os argumentos da Promotora de Justiça Coordenadora do Centro de Apoio Operacional das Promotorias de Justiça da Infância e da Juventude e da Pessoa Portadora de Deficiência, ajuizou ação direta de inconstitucionalidade, com pedido de liminar, alegando a inconstitucionalidade do

\footnotetext{
${ }^{192}$ DALLARI, Dalmo de Abreu. op. cit., p. 26.

${ }^{193}$ LAFER, Celso. A política e condição humana. Posfácio. In: ARENDT, Hannah. A condição humana, cit., p. 350-351.
} 
parágrafo $3^{\circ}$ do artigo 20 da Lei $8.742 / 93^{194}$, denominada Lei de Organização da Assistência Social, porquanto, ao fixar que o incapaz de prover a própria subsistência é aquele que possui renda per capita mensal inferior a 1/4 (um quarto) de salário mínimo, afastou da proteção grande número de idosos e portadores de deficiência que o constituinte quis proteger.

Defendeu a ilegalidade do mencionado artigo em função da previsão contida no artigo 203 da Constituição Federal que garante o benefício assistencial de um salário mínimo mensal à pessoa portadora de deficiência e ao idoso que comprovem não possuir meios de prover à própria manutenção ou tê-la provida por sua família. ${ }^{195}$

O STF decidiu o conflito na forma da ementa abaixo transcrita:

1. Argüição de inconstitucionalidade do parágrafo $3^{\circ}$ do art. 20 da Lei 8.742/93, que prevê o limite máximo de 1/4 do salário mínimo de renda mensal "per capita" da família para que seja incapaz de prover a manutenção do idoso e do deficiente físico, ao argumento de que esvazia ou inviabiliza o exercício do direito ao benefício de um salário mínimo conferido pelo inciso $V$ do art. 203 da Constituição.

2. A concessão de liminar, suspendendo a disposição legal impugnada, faria com que a norma constitucional voltasse a ter eficácia contida, a qual, por isto, ficaria novamente dependente de regulamentação legal para ser aplicada, privando a Administração de conceder novos benefícios até o julgamento final da ação.

3. O dano decorrente de suspensão cautelar da norma legal é maior do que a sua manutenção no sistema jurídico.

4. Pedido cautelar indeferido.

Sob essa fundamentação, a liminar foi indeferida e a ação cautelar julgada improcedente.

O relator da ação cautelar, Ministro Maurício Corrêa, argumentou que a norma constitucional impugnada não seria auto-aplicável porque dependeria de lei regulamentadora, de forma que o $\S 3^{\circ}$ do artigo 20 da LOAS teria cumprido o seu papel ao definir o conceito do que seria família incapaz de prover o necessitado.

\footnotetext{
194،AArt. 20 - O benefício de prestação continuada é a garantia de 1 (um) salário mínimo mensal à pessoa portadora de deficiência e ao idoso com 70 (setenta) anos ou mais e que comprovem não possuir meios de prover a própria manutenção e nem de tê-la provida por sua família. [...] $\S 3^{\circ}$ - Considera-se incapaz de prover a manutenção da pessoa portadora de deficiência ou idosa a família cuja renda mensal per capita seja inferior a 1/4 (um quarto) do salário mínimo."

195“"Art. 203. A assistência social será prestada a quem dela necessitar, independentemente de contribuição à seguridade social, e tem por objetivos: [...] V - a garantia de um salário mínimo de benefício mensal à pessoa portadora de deficiência e ao idoso que comprovem não possuir meios de prover à própria manutenção ou de tê-la provida por sua família, conforme dispuser a lei."
} 
O legislador ordinário, disse o Ministro relator, cumpriu o seu dever de editar a lei impugnada, estabelecendo um parâmetro, que teve a virtude de dar eficácia à norma constitucional. Ademais, argumentou, é "axiomático no direito que a estipulação de pensão e de outros benefícios deve levar em conta, fundamentalmente, dois fatores; de um lado a necessidade do beneficiário, e de outro, a possibilidade de quem arca com o encargo".

A ação principal, por sua vez, relatada pelo Ministro Ilmar Galvão, também foi julgada improcedente por maioria de votos. Eis a ementa do acórdão:

Constitucional. Impugna dispositivo de lei federal que estabelece o critério para receber o benefício do inciso V do art. 203, da CF. Inexiste a restrição alegada em face ao próprio dispositivo constitucional que reporta à lei para fixar os critérios de garantia do benefício de salário mínimo à pessoa portadora de deficiência física e ao idoso. Esta lei traz hipótese objetiva de prestação assistencial do estado. Ação julgada improcedente

Analisando os votos proferidos, verificamos que os Ministros Ilmar Galvão e Néri da Silveira emprestaram à norma impugnada interpretação conforme a Constituição, sustentando a típica presença de caso no qual se faz invocável o entendimento da Suprema Corte, segundo o qual, existindo duas ou mais formas de se interpretar o texto constitucional, e revestindo-se apenas uma delas de constitucionalidade, a Excelsa Corte não declara a inconstitucionalidade, mas proclama a interpretação segundo a Constituição.

Para eles o artigo impugnado teria apenas se limitado a instituir presunção juris et de jure da necessidade da prestação assistencial, sem excluir a possibilidade de serem comprovados outros casos de efetiva falta de meios para que o portador de deficiência possa prover a própria manutenção ou tê-la provida por sua família. No caso do $\S 3^{\circ}$ do artigo 20 da LOAS, a comprovação da miserabilidade seria dispensável, continuando nos demais casos a sujeitar-se à regra geral da comprovação.

Os demais Ministros presentes na sessão, Ministro Carlos Velloso, Moreira Alves, Néri da Silveira, Octávio Gallotti, Sepúlveda Pertence, Ilmar Galvão, Maurício Corrêa e Nelson Jobim votaram pela improcedência da ação. 
O Ministro Nelson Jobim entendeu que o gozo do benefício depende de comprovar na forma da lei, e "esta entendeu de comprovar dessa forma", ou seja, possuir renda pessoal ou familiar "per capita" inferior a $1 / 4$ do salário mínimo.

O Ministro Maurício Corrêa seguiu o mesmo entendimento exposto quando do indeferimento da liminar na ação cautelar, sendo acompanhado pela maioria dos presentes na sessão. A fundamentação do seu discurso decisório baseou-se em quatro premissas, a saber:

1- não examinar o caso no contexto de uma escala axiológica;

2- na classificação doutrinária das normas constitucionais em normas de eficácia plena, de eficácia contida, de eficácia limitada e programática, o que o levou ao entendimento de que a norma constitucional impugnada, que assegura de forma expressa proteção especial ao idoso e ao deficiente carentes não seria auto-aplicável por depender de norma regulamentadora os conceitos de família, pessoa portadora de deficiência e família incapaz de prover o necessitado;

3- ser axiomático no direito que a estipulação de pensão e de outros benefícios deve levar em conta, fundamentalmente, a necessidade do beneficiário e a possibilidade de quem arca com o encargo;

4- haver o legislador ordinário, bem ou mal, cumprido o dever de editar a lei, que teve a virtude de dar eficácia a norma constitucional. "Ruim com ela, pior sem ela", ponderou o Ministro.

Esse acórdão é extremamente interessante porque demonstra dois aspectos importantes dos direitos humanos sociais. O primeiro deles, já retratado por Habermas, é a verificação palpável de que, no Estado de bem-estar social, a legislação que agasalha o sistema é criada pelo Poder Legislativo através de barganhas e negociações, formando uma enorme "colcha de retalhos" capaz de atender, ao mesmo tempo, os interesses antagônicos do sistema capitalista e do Estado de bem- estar social, já que nenhum Estado intervencionista possui poder bastante para domesticar o sistema do programa capitalista e nem o sistema capitalista pode viver sem o Estado social. Estamos na presença de uma legislação que concede direitos com uma mão e os retira com a outra, gênese da origem conflituosa dos direitos sociais. É apreensível que a ordem jurídica constitucional tenha outorgado mais direitos do que a sistema econômico gostaria ou de que as forças dominantes da sociedade estão dispostas a conceder. 
O segundo deles é a importância do papel desempenhado pelo Poder Judiciário nesse cenário, ${ }^{196}$ ao qual é atribuído o poder e o dever de arbitrar o sentido de uma norma jurídica e aplicá-la ao caso concreto de forma efetiva. Esse arbitramento do sentido da norma e sua aplicação coativa vai substituir o papel da força e da violência concreta pela violência do direito, domesticada e aceita pela sociedade. Por isso que falamos que a positividade da norma, assim como a positividade de uma interpretação estão ligadas sempre a uma gradação de poder e Direito e Poder correspondem as duas faces da mesma moeda ${ }^{197}$.

Temos assim que a decisão judicial, qualificada como norma jurídica individual, equivale a continuação do processo de produção do direito, do geral para o individual. Trata-se da individualização para o caso específico da norma geral ou abstrata. Nesse sentido, a interpretação jurídica deixa de ser concebida tão somente como interpretação da lei, para ser pensada como forma de realização do direito

No caso em exame, observamos que o Poder Judiciário ao continuar o processo de produção do direto, individualizando a norma jurídica e a aplicando ao caso concreto, conseguiu prestigiar a legislação "colcha de retalhos", sem o mais insignificante esforço para curvar-se à força normativa da Constituição e adaptação das leis, proferindo, de forma fundamentada, uma decisão que levou de nenhum lugar a lugar algum.

Os preceitos dirigidos à prestação positiva do Estado não são imediatamente realizáveis sem a interpretação do próprio hermeneuta, a quem cabe promover a identificação dos meios possíveis à consecução de finalidade, o que não veio a ocorrer no presente caso. Como anota Nelson Hungria, a vida é a variedade infinita "e nunca lhe assentam com irrepreensível justeza as 'roupas feitas' da lei e dos figurinos da doutrina. Se

\footnotetext{
${ }^{196}$ NEVES, António Castanheira. op. cit., p. 11-14.

197، A convergência entre Direito e Poder, explicita Bobbio, não significa reduzir o direito à força, nem o seu inverso, como Kelsen enunciou e Ross sustentou ao fazer da força apenas o objeto da regulamentação jurídica. O Poder é necessário para a realização do Direito no seu sentido amplo da ordem jurídica, pois todo legislador se vale da força para organizar a sociedade. Isto se verifica seja no topo da pirâmide jurídica, no processo de criação normativa, seja na sua base, através da sanção que é o meio para reforçar a eficácia - outro conceito básico do Direito Positivo - das normas que compõem o ordenamento. Em síntese, há uma circularidade entre BOBBIO, como grande mestre dos dois campos, foi aprofundando pelo método de aproximações sucessivas que o caracteriza, em trabalhos posteriores à Teoria do Ordenamento.'Direito e Poder, que deriva dos nexos de complementaridade entre Teoria Política e Teoria Jurídica que LAFER, Celso. Norberto Bobbio, Teoria do Ordenamento Jurídico. Revista da PósGraduação da Faculdade de Direito da USP, São Paulo, v. 2, p. 131, 2000.
} 
o juiz não dá de si para dizer o direito de cada caso, a sua justiça será a do leito de Procusto: ao invés de medir-se com os fatos, este é que terão de medir-se com ela."198

Neste caso, a previsão do benefício assistencial encontra-se disciplinada na Constituição Federal, fruto da vontade pública nacional, por isso cogentes e eficazes a suas promessas. Se o Estado prometeu o benefício, cumpre adimpli-lo, porquanto é essa a vontade política nacional para construir uma sociedade justa, livre e solidária.

Revela notar que esse caso, em termos jurídicos, é da mesma natureza do anterior, oportunidade na qual o Judiciário se curvou à força normativa da Constituição, protegendo o direito do menor ao ensino fundamental a partir de seis anos, embora a legislação infra-constitucional o houvesse restringido.

No caso anterior, o raciocínio do relator, embasado na fundamentação do Ministro Celso de Mello (ADPF 45/DF), foi estabelecido na seguinte ordem: identificação dos princípios constitucionais gerais e dos princípios constitucionais específicos, aplicando-os ao caso concreto

No presente caso, os comandos foram desenvolvidos de forma aleatória, retirando a interpretação do ordenamento jurídico de seu assento constitucional. Analisemos o discurso decisório:

Primeira premissa do magistrado: não valoração da norma. Esta premissa apresenta-se desvinculada da estrutura escalonada do nosso ordenamento jurídico na qual a norma infra-constitucional deve ser compatível com a Constituição e com os princípios por ela adotados, seguindo a Lei Orgânica da Assistência Social a mesma regra geral. O direito, como sabemos, abriga uma ordem de valores que se realizam por instrumentos normativos e a Constituição Federal é o lugar próprio desse reconhecimento. Falar em direitos humanos, no Brasil, é falar da Constituição e dos valores por ela adotados em seus princípios orientadores.

Neste sentido, a nossa constituição, típica Constituição programática de âmbito dirigente, consagra princípios, que sinalizam os vetores da direção que ela busca imprimir à sociedade, exsurgindo a dignidade da pessoa humana como princípio que confere legitimação ético-jurídica à ordem normativa sobre a qual se edifica e estrutura o Estado de Democrático de Direito, representativo de um consenso universal de que reside na pessoa humana o valor fundante do Estado e da ordem que lhe dá suporte institucional.

\footnotetext{
${ }^{198}$ HUNGRIA, Nelson. op. cit., v. 1, t. 1, p. 63.
} 
Dessa forma, não valorar significa afastar os princípios constitucionais. Premissa equivocada de acordo com o nosso ordenamento jurídico.

Segunda premissa do magistrado: considerar a norma constitucional violada de eficácia contida. A escolha desta premissa põe de lado a circunstância de os direitos humanos serem também obrigações humanas. Nenhuma norma constitucional que albergue esses direitos pode ser considerada como norma de eficácia contida no caso concreto, porque todos os direitos fundamentais representam valores da cultura de um povo, cabendo ao juiz, enquanto representante do poder do Estado, revelar o valor consagrado na norma e preencher as lacunas necessárias à sua aplicação. Desconsidera também que a norma constitucional que cria direito, que depende só do próprio direito, é auto-aplicável, porque o direito ou está previsto e pode ser imediatamente aplicado ou está omisso, cabendo ao Judiciário declará-lo e explicitá-lo, preenchendo, para tanto, as lacunas necessárias.

Com efeito, cabe ao Judiciário declarar e garantir os direitos fundamentais, competindo ao Executivo e ao Legislativo respeitá-los e realizá-los. Os direitos humanos, na moderna interpretação constitucional, são dotados de eficácia imediata, porque conferem direitos subjetivos aos cidadãos e à coletividade, que devem ser amparados em sua realização pelo Poder Judiciário. Para utilizar as palavras de Canotilho, a atuação estatal na concretização da sua missão constitucional deve orientar-se pelo Princípio da Máxima Efetividade da Constituição de sorte que "a uma norma constitucional deve ser atribuído o sentido que maior eficácia lhe dê. É um princípio operativo em relação a todas e quaisquer normas constitucionais, e embora a sua origem esteja ligada à tese da actualidade das normas programáticas (Thoma), é hoje sobretudo invocado no âmbito dos direitos fundamentais (no caso de dúvida deve preferir-se a interpretação que reconheça maior eficácia aos direitos fundamentais)". 199

O raciocínio desenvolvido passou ao largo dos princípios da imediatidade, segundo o qual os direitos subjetivos declarados na Constituição têm de ser outorgados imediatamente e independem de qualquer outra regulamentação intermediária para serem aplicados, bem como o da maior extensibilidade, segundo o qual as normas que outorgam direitos fundamentais têm interpretação ampla, porque não são mera concessão do Estado, mas valores que não podem ser restringidos.

${ }^{199}$ CANOTILHO, Joaquim José Gomes. op. cit.,. p. 1208. 
Além disso, poderemos dizer que há uma íntima vinculação entre o benefício assistencial discutido no caso concreto, o direito à vida e o princípio da dignidade da pessoa humana, que confere legitimação ético-jurídica à ordem normativa sobre a qual se edifica e se estrutura o Estado Democrático de Direito, representativo do consenso universal de que reside na pessoa humana o valor fundante do Estado e da ordem que lhe dá suporte institucional, princípio que não foi sequer objeto de consideração pelos magistrados.

Podemos dizer que os direitos sociais à educação, saúde, trabalho, moradia, lazer, segurança, previdência social, proteção à maternidade, infância e a assistência aos desamparados, são direitos sensíveis porque a sua ineficácia no mundo contemporâneo significa o início da exclusão social da pessoa humana, de forma que qualquer conclusão deve sempre levar a sua aplicação em grau suficiente para permitir, no mínimo, a existência e permanência da pessoa humana na sociedade.

Como pondera Bobbio "o jurista não pode compreender o significado de uma proposição normativa, sem remontar à realidade social, da qual essa proposição tirou não só a sua razão de ser, mas também as noções de que é composta" e, embora, o juiz não seja partícipe da formulação das normas de direito, é responsável pela sua aplicação. ${ }^{200}$

Nesse sentido, verificamos que a premissa maior fixada deve ser sempre um princípio constitucional otimizado, porque esvaziar-lhe o conteúdo, amesquinhar ou a reduzir a sua eficácia significa privar a sociedade de direitos já reconhecidos. Vale a pena lembrar que os princípios constitucionais são valores consensualmente aceitos e positivados pela sociedade. Aliás, "quando dizemos que a lei deve ser interpretada segundo "seu espírito", e não apenas por aquilo que ela verbalmente enuncia, não estamos afirmando outra coisa senão que o significado real dos modelos jurídicos é o resultado de um processo hermenêutico, consubstanciado em proposições e modelos capazes de revelarnos o valor ou a razão axiológica do que é preceituado ${ }^{201}$ ".

Convém registrar que o Ministro Gilmar Mendes, nos autos da Reclamação 4374, indeferiu o pedido do INSS e concedeu o benefício assistencial a um trabalhador rural de Pernambuco, com renda mensal superior a $1 / 4$ de salário mínimo. Sustentou que o próprio legislador tem revelado uma intenção de tornar mais elásticos os critérios fixados

\footnotetext{
${ }^{200}$ BOBBIO, Norberto. Teoria della scienza del diritto, cit., p. 176.

${ }^{201}$ REALE, Miguel. Teoria tridimensional do direito, teoria da justiça, fontes e modelos do direito, cit., $\mathrm{p}$. 315.
} 
pela Constituição (art. 203) para concessão de benefícios assistenciais, assim como as leis que instituíram os programas Bolsa Família, Bolsa Escola, Estatuto do Idoso e outros. E concluiu que diante de todas as perplexidades sobre o tema, é certo que o Plenário do Supremo Tribunal Federal terá de enfrentá-lo novamente.

\subsection{O Judiciário e o Direito à Saúde (Agravo de Instrumento no RE 393.175/RS e ADPF 45)}

Trata-se de agravo de instrumento, ajuizado pelo Estado do Rio Grande do Sul, contra a decisão que conheceu e deu provimento ao apelo extremo deduzido por Luiz Marcelo Dias e outra. A parte agravante requer o não provimento do recurso extraordinário deduzido.

O acórdão vem assim ementado:

O DIREITO À SAÚDE REPRESENTA CONSEQÜÊNCIA CONSTITUCIONAL INDISSOCIÁVEL DO DIREITO À VIDA.

- O direito público subjetivo à saúde representa prerrogativa jurídica indisponível assegurada à generalidade das pessoas pela própria Constituição da República (art. 196). Traduz bem jurídico constitucionalmente tutelado, por cuja integridade deve velar, de maneira responsável, o Poder Público, a quem incumbe formular - e implementar - políticas sociais e econômicas idôneas que visem a garantir, aos cidadãos, o acesso universal e igualitário à assistência farmacêutica e médico-hospitalar.

- O direito à saúde - além de qualificar-se como direito fundamental que assiste a todas as pessoas - representa conseqüência constitucional indissociável do direito à vida. O Poder Público, qualquer que seja a esfera institucional de sua atuação no plano da organização federativa brasileira, não pode mostrar-se indiferente ao problema da saúde da população, sob pena de incidir, ainda que por censurável omissão, em grave comportamento inconstitucional.

\section{A INTERPRETAÇÃO DA NORMA PROGRAMÁTICA NÃO PODE $\begin{array}{llll}\text { TRANSFORMÁ-LA } & \text { EM } & \text { PROMESSA } & \text { CONSTITUCIONAL }\end{array}$ INCONSEQÜENTE.}

- O caráter programático da regra inscrita no art. 196 da Carta Política que tem por destinatários todos os entes políticos que compõem, no plano institucional, a organização federativa do Estado brasileiro - não pode converter-se em promessa constitucional inconseqüente, sob pena de o Poder Público, fraudando justas expectativas nele depositadas pela coletividade, substituir, de maneira ilegítima, o cumprimento de seu 
impostergável dever, por um gesto irresponsável de infidelidade governamental ao que determina a própria Lei Fundamental do Estado.

DISTRIBUIÇÃO GRATUITA, A PESSOAS CARENTES, DE MEDICAMENTOS ESSENCIAIS À PRESERVAÇÃO DE SUA VIDA E/OU DE SUA SAÚDE: UM DEVER CONSTITUCIONAL QUE O ESTADO NÃO PODE DEIXAR DE CUMPRIR.

- O reconhecimento judicial da validade jurídica de programas de distribuição gratuita de medicamentos a pessoas carentes, inclusive àquelas portadoras do vírus HIV/AIDS, dá efetividade a preceitos fundamentais da Constituição da República (arts. 5º, caput, e 196) e representa, na concreção do seu alcance, um gesto reverente e solidário de apreço à vida e à saúde das pessoas, especialmente daquelas que nada têm e nada possuem, a não ser a consciência de sua própria humanidade e de sua essencial dignidade. Precedentes do STF.

\section{MULTA E EXERCÍCIO ABUSIVO DO DIREITO DE RECORRER.}

- O abuso do direito de recorrer - por qualificar-se como prática incompatível com o postulado ético-jurídico da lealdade processual constitui ato de litigância maliciosa repelido pelo ordenamento positivo, especialmente nos casos em que a parte interpõe recurso com intuito evidentemente protelatório, hipótese em que se legitima a imposição de multa.

A multa a que se refere o art. 557, $\S 2^{\circ}$, do CPC possui função inibitória, pois visa a impedir o exercício abusivo do direito de recorrer e a obstar a indevida utilização do processo como instrumento de retardamento da solução jurisdicional do conflito de interesses. Precedentes.

Entendeu o relator, Ministro Celso de Mello, que o sentido de fundamentalidade do direito à saúde - representa, no contexto da evolução histórica dos direitos básicos da pessoa humana, uma das expressões mais relevantes das liberdades reais ou concretas, impondo ao Poder Público um dever de prestação positiva que somente se terá por cumprido pelas instâncias governamentais, quando estas adotarem providências destinadas a promover, em plenitude, a satisfação efetiva da determinação ordenada pelo texto constitucional.

Ponderou, ainda, que mais do que a simples positivação dos direitos sociais - que traduz estágio necessário ao processo de sua afirmação constitucional e que atua como pressuposto indispensável à sua eficácia jurídica, recai, sobre o Estado, inafastável vínculo institucional consistente em conferir real efetividade a tais prerrogativas básicas, em ordem a permitir, às pessoas, nos casos de injustificável inadimplemento da obrigação estatal, que tenham elas acesso a um sistema organizado de garantias instrumentalmente 
vinculadas à realização, por parte das entidades governamentais, da tarefa que lhes impôs a própria Constituição.

Acresceu, ainda, que não basta que o Estado proclame o reconhecimento formal de um direito. Torna-se essencial que, para além da simples declaração constitucional desse direito, seja ele integralmente respeitado e plenamente garantido, especialmente naqueles casos em que o direito - como o direito à saúde - se qualifica como prerrogativa jurídica de que decorre o poder do cidadão de exigir, do Estado, a implementação de prestações positivas impostas pelo próprio ordenamento constitucional. Cumpre assinalar, finalmente, que a essencialidade do direito à saúde fez com que o legislador constituinte qualificasse, como prestações de relevância pública, as ações e serviços de saúde (CF, art. 197), em ordem a legitimar a atuação do Ministério Público e do Poder Judiciário naquelas hipóteses em que os órgãos estatais, anomalamente, deixassem de respeitar o mandamento constitucional, frustrando-lhe, arbitrariamente, a eficácia jurídico-social, seja por intolerável omissão, seja por qualquer outra inaceitável modalidade de comportamento governamental desviante.

Essa mesma matéria foi analisada inúmeras vezes pelo STF (Agravo de Instrumento 462563/RS, Agravo de Instrumento 532687/MG, Agravo de Instrumento 537237/PE, Agravo de Instrumento 570455/RS, Agravo Regimental no Agravo de Instrumento 238328/RS, Agravo Regimental no Agravo de Instrumento 486816/ RJ, Agravo Regimental em Petição 1246/SC, Agravo Regimental no Recurso Extraordinário 255627 / RS, Agravo Regimental no Recurso Extraordinário 257109 / RS, Agravo Regimental no Recurso Extraordinário 259508 / RS, Agravo Regimental no Recurso Extraordinário 268479 / RS, Agravo Regimental no Recurso Extraordinário 271286 / RS, Agravo Regimental no Recurso Extraordinário 273834 / RS, Agravo Regimental no Recurso Extraordinário 279519/RS, Argüição de Descumprimento de Preceito Fundamental 45/DF, Petição 1246/SC, Recurso Extraordinário 195186/ RS, Recurso Extraordinário 195192/ RS, Recurso Extraordinário 198263/ RS, Recurso Extraordinário 198265/ RS, Recurso Extraordinário 232335/RS, Recurso Extraordinário 237367/ RS, Recurso Extraordinário 242859/ RS, Recurso Extraordinário 248304/ RS, Recurso Extraordinário 256327/ RS, Recurso Extraordinário 264269/ RS, Recurso Extraordinário 
267612/RS, Recurso Extraordinário 297276/ SP, Recurso Extraordinário 342413/ PR, Recurso Extraordinário 353336/ RS, Recurso Extraordinário 393175/RS). ${ }^{202}$

Em todas elas o medicamento ou tratamento pedido foi deferido, não havendo nenhum voto divergente nesses acórdãos. Em nenhuma dessas decisões o Supremo Tribunal Federal admitiu a escassez de recursos como argumento aceitável para impedir a concessão de um medicamento ou tratamento médico. No entanto, todas essas ações são individuais; nenhum dos acórdãos analisados decidiu acerca de tutela coletiva do direito à saúde ${ }^{203}$.

$\mathrm{Na}$ Pet 1246, em que se pede transplante das células mioblásticas para tratamento de doença rara denominada Distrofia Muscular de Duchene, o Ministro Celso de Mello conclui que: "Entre proteger a inviolabilidade do direito à vida, que se qualifica como direito subjetivo inalienável assegurado pela própria Constituição da República (art. $5^{\circ}$, caput), ou fazer prevalecer, contra essa prerrogativa fundamental, um interesse financeiro e secundário do Estado, entendo - uma vez configurado esse dilema - que razões de ordem ético jurídica impõem ao julgador uma só e possível opção: o respeito indeclinável à vida".

Outras decisões também citam esta passagem: RE 267612 / RS, AI 570455/RS, AgRg no RE 271286/RS, RE 198265/ RS, RE 248304/ RS, AgRg no RE 273834-4/ 393175/RS.

\footnotetext{
202 "Das 31 decisões analisadas, 11 pedem medicamentos para HIV (AgRg no AI 238328;AgRg no RE 257109; AgRg no RE 259508; AgRg no RE 268479; AgRg no RE 271286; AgRg no RE 273834; RE 232335; RE 237367; RE 242859; RE 264269; RE 267612); 3 pedem medicamento não fabricado no Brasil para tratamento de Fenilcetonúria (RE195192; RE 198263; RE 198265), doença hereditária que se caracteriza pela falta de uma enzima em maiores ou menores proporções, impedindo que o organismo metabolize $e$ elimine o aminoácido fenilalanina, que, em excesso no sangue, é tóxico,atacando principalmente o cérebro e causando deficiência mental,; 2 pedem medicamento para tratamento de Hepatite C (AI 537237 e RE 353336); 2 pedem tratamento a base de implante de céluas-tronco em clínica nos Estados Unidos para distrofia muscular de Duchene (Pet 1246; AgRg em Pet 1246); 1 pede medicamento blecosol spary e aparelho nebulizador, para tratamento de asma e bronquite (AI 462563); 1 pede medicamento para tratamento de tumor carcinóide de fígado (RE 342413); 1 pede medicamento esquizofrenia paranóide e doença maníaco depressiva crônica (RE 393175); 1 pede medicamento para Status Marmóreo, patologia de fundo neurológico,caracterizada pela impregnação de bilirrubina no cérebro (RE 248304); 1 pede medicamento para Glaucoma Crônico (AI 570455); 1 pede fornecimento de oxigênio (AI 532687); em 6 decisões, não estão identificados a doença para a qual se pede o medicamento (AgRg no AI 486816; AgRg no RE 255627; AgRg no RE 279519; RE 195186; RE 256327; RE 297276)." (WANG, Daniel Wei Liang. Escassez de recursos, custos dos direitos e reserva do possível na jurisprudência do Supremo Tribunal Federal. 2006. (Monografia) - Sociedade Brasileira de Direito Público, São Paulo, 2006).

${ }^{203}$ Id. Ibid.
} 
Na mesma linha do Pet 1246 encontra-se a decisão do Ministro Sidney Sanches no RE 198263/ RS, em que se pede medicamento para tratamento de fenilcetonúria: "em matéria tão relevante como a saúde, descabem disputas menores sobre legislação, muito menos sobre verbas, questão de prioridade"

No RE 342413/ PR, em que se pede medicamento para o tratamento de tumor carcinóide de fígado, a Ministra Ellen Gracie diz que “obstáculo de ordem burocrática ou orçamentária (...) não podem ser entraves ao cumprimento constitucional que garante o direito à vida".

No mesmo sentido a decisão no RE 195192/ RS, no qual se pede fornecimento de medicamento para tratamento de fenilcetonúria. O Ministro Marco Aurélio conclui que "problemas orçamentários não podem obstaculizar o implemento do que previsto constitucionalmente".

No agravo, AI 537237/PE, que pede medicamento para paciente com hepatite C, o Ministro Sepúlveda Pertence decidiu que "a falta de prévia dotação orçamentária não serve como justificativa para inviabilizar o direito".

Acerca da questão relativa à reserva do possível e da intervenção do Poder Judiciário na implementação dos direitos humanos sociais, vale a pena a leitura do voto do Ministro Celso de Mello nos autos da ADPF 45/2004:

"O desrespeito à Constituição tanto pode ocorrer mediante ação estatal quanto mediante inércia governamental. A situação de inconstitucionalidade pode derivar de um comportamento ativo do Poder Público, que age ou edita normas em desacordo com o que dispõe a Constituição, ofendendo-lhe, assim, os preceitos e os princípios que nela se acham consignados. Essa conduta estatal, que importa em um facere (atuação positiva), gera a inconstitucionalidade por ação.

- Se o Estado deixar de adotar as medidas necessárias à realização concreta dos preceitos da Constituição, em ordem a torná-los efetivos, operantes e exeqüíveis, abstendo-se, em conseqüência, de cumprir o dever de prestação que a Constituição lhe impôs, incidirá em violação negativa do texto constitucional. Desse non facere ou non praestare, resultará a inconstitucionalidade por omissão, que pode ser total, quando é nenhuma a providência adotada, ou parcial, quando é insuficiente a medida efetivada pelo Poder Público.

- A omissão do Estado - que deixa de cumprir, em maior ou em menor extensão, a imposição ditada pelo texto constitucional - qualifica-se como comportamento revestido da maior gravidade político-jurídica, eis que, mediante inércia, o Poder Público também desrespeita a Constituição, também ofende direitos que nela se fundam e também impede, por 
ausência de medidas concretizadoras, a própria aplicabilidade dos postulados e princípios da Lei Fundamental."

(RTJ 185/794-796, Rel. Min. CELSO DE MELLO, Pleno)

É certo que não se inclui, ordinariamente, no âmbito das funções institucionais do Poder Judiciário - e nas desta Suprema Corte, em especial - a atribuição de formular e de implementar políticas públicas (JOSÉ CARLOS VIEIRA DE ANDRADE, "Os Direitos Fundamentais na Constituição Portuguesa de 1976”, p. 207, item n. 05, 1987, Almedina, Coimbra), pois, nesse domínio, o encargo reside, primariamente, nos Poderes Legislativo e Executivo.

Tal incumbência, no entanto, embora em bases excepcionais, poderá atribuir-se ao Poder Judiciário, se e quando os órgãos estatais competentes, por descumprirem os encargos político-jurídicos que sobre eles incidem, vierem a comprometer, com tal comportamento, a eficácia e a integridade de direitos individuais e/ou coletivos impregnados de estatura constitucional, ainda que derivados de cláusulas revestidas de conteúdo programático.

Cabe assinalar, presente esse contexto - consoante já proclamou esta Suprema Corte - que o caráter programático das regras inscritas no texto da Carta Política "não pode converter-se em promessa constitucional inconseqüente, sob pena de o Poder Público, fraudando justas expectativas nele depositadas pela coletividade, substituir, de maneira ilegítima, o cumprimento de seu impostergável dever, por um gesto irresponsável de infidelidade governamental ao que determina a própria Lei Fundamental do Estado" (RTJ 175/1212-1213, Rel. Min. CELSO DE MELLO).

Não deixo de conferir, no entanto, assentadas tais premissas, significativo relevo ao tema pertinente à "reserva do possível" (STEPHEN HOLMES/CASS R. SUNSTEIN, "The Cost of Rights", 1999, Norton, New York), notadamente em sede de efetivação e implementação (sempre onerosas) dos direitos de segunda geração (direitos econômicos, sociais e culturais), cujo adimplemento, pelo Poder Público, impõe e exige, deste, prestações estatais positivas concretizadoras de tais prerrogativas individuais e/ou coletivas.

É que a realização dos direitos econômicos, sociais e culturais - além de caracterizar-se pela gradualidade de seu processo de concretização depende, em grande medida, de um inescapável vínculo financeiro subordinado às possibilidades orçamentárias do Estado, de tal modo que, comprovada, objetivamente, a incapacidade econômico-financeira da pessoa estatal, desta não se poderá razoavelmente exigir, considerada a limitação material referida, a imediata efetivação do comando fundado no texto da Carta Política.

Não se mostrará lícito, no entanto, ao Poder Público, em tal hipótese mediante indevida manipulação de sua atividade financeira e/ou políticoadministrativa - criar obstáculo artificial que revele o ilegítimo, arbitrário e censurável propósito de fraudar, de frustrar e de inviabilizar o estabelecimento e a preservação, em favor da pessoa e dos cidadãos, de condições materiais mínimas de existência.

Cumpre advertir, desse modo, que a cláusula da "reserva do possível" ressalvada a ocorrência de justo motivo objetivamente aferível - não 
pode ser invocada, pelo Estado, com a finalidade de exonerar-se do cumprimento de suas obrigações constitucionais, notadamente quando, dessa conduta governamental negativa, puder resultar nulificação ou, até mesmo, aniquilação de direitos constitucionais impregnados de um sentido de essencial fundamentalidade.

Daí a correta ponderação de ANA PAULA DE BARCELLOS ("A Eficácia Jurídica dos Princípios Constitucionais", p. 245-246, 2002, Renovar):

"Em resumo: a limitação de recursos existe e é uma contingência que não se pode ignorar. $\mathrm{O}$ intérprete deverá levá-la em conta ao afirmar que algum bem pode ser exigido judicialmente, assim como o magistrado, ao determinar seu fornecimento pelo Estado. Por outro lado, não se pode esquecer que a finalidade do Estado ao obter recursos, para, em seguida, gastá-los sob a forma de obras, prestação de serviços, ou qualquer outra política pública, é exatamente realizar os objetivos fundamentais da Constituição.

A meta central das Constituições modernas, e da Carta de 1988 em particular, pode ser resumida, como já exposto, na promoção do bemestar do homem, cujo ponto de partida está em assegurar as condições de sua própria dignidade, que inclui, além da proteção dos direitos individuais, condições materiais mínimas de existência. Ao apurar os elementos fundamentais dessa dignidade (o mínimo existencial), estar-seão estabelecendo exatamente os alvos prioritários dos gastos públicos. Apenas depois de atingi-los é que se poderá discutir, relativamente aos recursos remanescentes, em que outros projetos se deverá investir. $\mathrm{O}$ mínimo existencial, como se vê, associado ao estabelecimento de prioridades orçamentárias, é capaz de conviver produtivamente com a reserva do possível." (grifei)

Vê-se, pois, que os condicionamentos impostos, pela cláusula da "reserva do possível", ao processo de concretização dos direitos de segunda geração - de implantação sempre onerosa -, traduzem-se em um binômio que compreende, de um lado, (1) a razoabilidade da pretensão individual/social deduzida em face do Poder Público e, de outro, (2) a existência de disponibilidade financeira do Estado para tornar efetivas as prestações positivas dele reclamadas.

Desnecessário acentuar-se, considerado o encargo governamental de tornar efetiva a aplicação dos direitos econômicos, sociais e culturais, que os elementos componentes do mencionado binômio (razoabilidade da pretensão + disponibilidade financeira do Estado) devem configurar-se de modo afirmativo e em situação de cumulativa ocorrência, pois, ausente qualquer desses elementos, descaracterizar-se-á a possibilidade estatal de realização prática de tais direitos.

Não obstante a formulação e a execução de políticas públicas dependam de opções políticas a cargo daqueles que, por delegação popular, receberam investidura em mandato eletivo, cumpre reconhecer que não se revela absoluta, nesse domínio, a liberdade de conformação do legislador, nem a de atuação do Poder Executivo.

É que, se tais Poderes do Estado agirem de modo irrazoável ou procederem com a clara intenção de neutralizar, comprometendo-a, a eficácia dos direitos sociais, econômicos e culturais, afetando, como decorrência causal de uma injustificável inércia estatal ou de um abusivo comportamento governamental, aquele núcleo intangível 
consubstanciador de um conjunto irredutível de condições mínimas necessárias a uma existência digna e essenciais à própria sobrevivência do indivíduo, aí, então, justificar-se-á, como precedentemente já enfatizado - e até mesmo por razões fundadas em um imperativo éticojurídico -, a possibilidade de intervenção do Poder Judiciário, em ordem a viabilizar, a todos, o acesso aos bens cuja fruição lhes haja sido injustamente recusada pelo Estado.

Extremamente pertinentes, a tal propósito, as observações de ANDREAS JOACHIM KRELL ("Direitos Sociais e Controle Judicial no Brasil e na Alemanha", p. 22-23, 2002, Fabris):

"A constituição confere ao legislador uma margem substancial de autonomia na definição da forma e medida em que o direito social deve ser assegurado, o chamado 'livre espaço de conformação' (...). Num sistema político pluralista, as normas constitucionais sobre direitos sociais devem ser abertas para receber diversas concretizações consoante as alternativas periodicamente escolhidas pelo eleitorado. A apreciação dos fatores econômicos para uma tomada de decisão quanto às possibilidades e aos meios de efetivação desses direitos cabe, principalmente, aos governos e parlamentos.

Em princípio, o Poder Judiciário não deve intervir em esfera reservada a outro Poder para substituí-lo em juízos de conveniência e oportunidade, querendo controlar as opções legislativas de organização e prestação, a não ser, excepcionalmente, quando haja uma violação evidente e arbitrária, pelo legislador, da incumbência constitucional.

No entanto, parece-nos cada vez mais necessária a revisão do vetusto dogma da Separação dos Poderes em relação ao controle dos gastos públicos e da prestação dos serviços básicos no Estado Social, visto que os Poderes Legislativo e Executivo no Brasil se mostraram incapazes de garantir um cumprimento racional dos respectivos preceitos constitucionais.

A eficácia dos Direitos Fundamentais Sociais a prestações materiais depende, naturalmente, dos recursos públicos disponíveis; normalmente, há uma delegação constitucional para o legislador concretizar o conteúdo desses direitos. Muitos autores entendem que seria ilegítima a conformação desse conteúdo pelo Poder Judiciário, por atentar contra o princípio da Separação dos Poderes (...).

Muitos autores e juízes não aceitam, até hoje, uma obrigação do Estado de prover diretamente uma prestação a cada pessoa necessitada de alguma atividade de atendimento médico, ensino, de moradia ou alimentação. Nem a doutrina nem a jurisprudência têm percebido o alcance das normas constitucionais programáticas sobre direitos sociais, nem lhes dado aplicação adequada como princípios-condição da justiça social.

A negação de qualquer tipo de obrigação a ser cumprida na base dos Direitos Fundamentais Sociais tem como consequiência a renúncia de reconhecê-los como verdadeiros direitos. (...) Em geral, está crescendo o grupo daqueles que consideram os princípios constitucionais e as normas sobre direitos sociais como fonte de direitos e obrigações e admitem a intervenção do Judiciário em caso de omissões inconstitucionais." (grifei)

Todas as considerações que venho de fazer justificam-se, plenamente, quanto à sua pertinência, em face da própria natureza constitucional da 
controvérsia jurídica ora suscitada nesta sede processual, consistente na impugnação a ato emanado do Senhor Presidente da República, de que poderia resultar grave comprometimento, na área da saúde pública, da execução de política governamental decorrente de decisão vinculante do Congresso Nacional, consubstanciada na Emenda Constitucional $\mathrm{n}^{\circ}$ 29/2000.

Ocorre, no entanto, como precedentemente já enfatizado no início desta decisão, que se registrou, na espécie, situação configuradora de prejudicialidade da presente argüição de descumprimento de preceito fundamental.

A inviabilidade da presente argüição de descumprimento, em decorrência da razão ora mencionada, impõe uma observação final: no desempenho dos poderes processuais de que dispõe, assiste, ao Ministro-Relator, competência plena para exercer, monocraticamente, o controle das ações, pedidos ou recursos dirigidos ao Supremo Tribunal Federal, legitimandose, em conseqüência, os atos decisórios que, nessa condição, venha a praticar.

Cumpre acentuar, por oportuno, que o Pleno do Supremo Tribunal Federal reconheceu a inteira validade constitucional da norma legal que inclui, na esfera de atribuições do Relator, a competência para negar trânsito, em decisão monocrática, a recursos, pedidos ou ações, quando incabíveis, estranhos à competência desta Corte, intempestivos, sem objeto ou que veiculem pretensão incompatível com a jurisprudência predominante do Tribunal (RTJ 139/53 - RTJ 168/174-175).

Nem se alegue que esse preceito legal implicaria transgressão ao princípio da colegialidade, eis que o postulado em questão sempre restará preservado ante a possibilidade de submissão da decisão singular ao controle recursal dos órgãos colegiados no âmbito do Supremo Tribunal Federal, consoante esta Corte tem reiteradamente proclamado (RTJ 181/1133-1134, Rel. Min. CARLOS VELLOSO - AI 159.892-AgR/SP, Rel. Min. CELSO DE MELLO, v.g.). 


\section{CONCLUSÕES}

\subsection{O direito brasileiro}

Podemos dizer que o direito brasileiro é texto. Ele aparece e se manifesta como texto prescritivo, ao contrário de uma novela ou de uma história, que constituem textos narrativos. Caracteriza-se como um conjunto de mensagens cuja função pragmática é dirigir, regular ou orientar as ações humanas. Nesse cenário, temos que o homicídio, como ação jurídica, por exemplo, só existe depois que o texto jurídico prescrever o que se deve entender por homicídio. A ação física de matar alguém existe independentemente do texto, mas a ação jurídica definida como homicídio só é possível em razão da preexistência do texto ${ }^{204}$. Logo, para uma ação ou fato qualquer pertencer ao Direito deverá ser qualificado juridicamente.

O direito é, assim, uma criação do homem montada por meio de palavras, mas não menos real do que as máquinas e os edifícios. Trata-se de um produto tipicamente humano, um artifício sem entidade corporal, como as formas geométricas ${ }^{205}$, qualificandose como um sistema de comunicação prescritivo, ordenador, cujas unidades de mensagem são as normas ${ }^{206}$ sistematizadas em um ordenamento identificado com os atributos de coerência, completude, claridade e não redundância.

Os direitos humanos sociais não inovam a regra geral. Constituem em um sistema prescritivo e ordenador, com princípios positivados na Constituição de 1988 e as regras em leis esparsas. Contudo, as unidades de mensagem transmitidas por esse sistema de princípios e regras se apresentam, muitas vezes, antagônicas.

Historicamente, os direitos humanos, são fruto de um combate ${ }^{207}$. Como assinala Bobbio, tiveram como primeiro adversário o poder religioso; depois o poder político, e, por fim, o poder econômico. ${ }^{208} \mathrm{Na}$ verdade, "a religião da fraternidade sempre se chocou com as ordens e valores deste mundo, e quanto mais coerentemente suas

\footnotetext{
${ }^{204}$ ROBLES, Gregório. Direito como texto: quatro estudos de teoria comunicacional do direito. Tradução de Roberto Barbosa Alves. Barueri: Manole, 2005. p. 28-29.

${ }^{205}$ Id. Ibid., p. 47.

${ }^{206}$ Id. Ibid., p. 87.

${ }^{207}$ LOCHAK, Danièle. op. cit.

${ }^{208}$ BOBBIO, Norberto. A era dos direitos, cit., p. 229.
} 
exigências foram levadas à prática, tanto mais agudo foi o choque". ${ }^{209}$ Assim, os direitos sociais são sempre conflituosos, desenhados entre relações de forças que parecem aleatórias, entre trevas e luz.

A ordem constitucional brasileira, virtualizando um Estado de bem-estar social, criou a legislação que agasalha os direitos humanos sociais através de barganhas e negociações, formando uma legislação estilo colcha de retalhos capaz de atender interesses adversos: sistema capitalista e Estado Social, que precisam coexistir. O capitalismo contemporâneo não pode existir sem o Estado bem-estar social, mas também não pode tolerar a sua expansão contínua. Por outro lado, nenhum Estado intervencionista possui poder bastante para domesticar o programa do sistema capitalista e nem o Estado de bemestar social pode dele prescindir. Dessa forma, a legislação que o abriga, tenta apaziguar antagonismos permanentes.

Podemos dizer que os direitos humanos sociais não se manifestam de forma simples, nem são prontamente manuseáveis, mas encontram-se estruturados sob a forma de banco de dados, em formato de rede, gerando infinitas informações, de difícil percepção, todas elas disponíveis instantânea e concomitantemente ${ }^{210}$. Positivados como colcha de retalhos, geram muitos sujeitos de direito e poucos sujeitos de obrigações, e não se pode apontar alguém totalmente responsável por seu cumprimento ou descumprimento.

Trata-se de um estilo de legislação que concede o direito com uma mão e o retira com a outra, emitindo inúmeras mensagens em sentido diversos e ao mesmo tempo, a fim de esconder quem são os reais participantes da rede de comunicação, bem como as relações de força que estabelecem. Esse tipo de legislação se adapta, com facilidade, ao Estado burocrático ou ao denominado "governo de ninguém"211, com o qual o Estado brasileiro guarda semelhanças. A chave da burocracia é transformar a solução em um problema e, para cumprir essa tarefa, as pessoas vão se desumanizando, convertendo-se em meras engrenagens.

Caracterizam-se os direitos humanos sociais como comandos dirigidos a uma prestação positiva do Estado. Contudo, além de apresentarem, por sua natureza linguística, sentido plurívoco, não são imediatamente realizáveis sem a atuação de um

\footnotetext{
${ }^{209}$ WEBER, Max. Economia e sociedade: fundamentos da sociologia compreensiva. Tradução de Regis Barbosa e Karen Elsabe Barbosa. 4. ed. Brasília: Ed. da UnB, 2000. v. 1, p. 379.

${ }^{210}$ OST, François, op. cit.

${ }^{211}$ Cf. ARENDT, Hannah. Eichmann em Jerusalém: um relato sobre a banalidade do mal, cit.
} 
intérprete, que deve promover a identificação dos meios possíveis à consecução das finalidades estabelecidas. ${ }^{212}$

No caso brasileiro, o intérprete competente para arbitrar o sentido da norma plurívoca, com vistas à aplicação e a concretização dos direitos humanos sociais, é o Judiciário. Por essa razão, entendíamos, no início de nosso trabalho, que a fixação de regras precisas de interpretação poderia conceder ao catálogo de direitos humanos sociais os atributos da simplicidade e fácil manuseabilidade.

Acreditávamos que a dificuldade para a concretização dos direitos humanos pelo Judiciário estaria sediada na ausência de regras específicas de interpretação, como as que existem no direito penal, direito tributário, etc., em virtude do caráter vago de suas formulações, bem como de sua subordinação às possibilidades orçamentárias do Estado poderiam funcionar como normas de segurança.

Realmente, o direito penal apresenta regras próprias de interpretação, objetivando proteger o indivíduo do Estado, assim como existem as do direito do trabalho para proteger o trabalhador, as do Código de Defesa do Consumidor para proteger o consumidor e as do direito tributário para proteger, de forma ambivalente, o Estado e o contribuinte.

Contudo, a análise dos casos selecionados possibilitou a conclusão de que não é a ausência de regras específicas de interpretação a razão da deficiência na concretização dos direitos humanos, da qual a necessidade de positivação de comandos específicos seria consequência decorrente, mas sim as premissas escolhidas pelo magistrado como ponto de partida de seu raciocínio.

Além desse fato, o lucro de positivar uma regra de interpretação não passa só por certa racionalização formal, mas implica, concomitantemente, em uma simplificação radical do material jurídico, característica estranha aos direitos humanos sociais. Assim, concluímos que a positivação de mais uma regra só aumentaria a entropia do sistema jurídico estudado e não traria a função simplificadora que se pretendia emprestar a ela no início de nossos trabalhos.

\footnotetext{
${ }^{212}$ FERRAZ JUNIOR, Tércio Sampaio. Interpretação e estudos da Constituição de 1988, cit., p. 11-19.
} 


\subsection{Os juízes}

Os magistrados são hoje os intérpretes autorizados do Direito e das aspirações de justiça. Ao Poder Judiciário é atribuído o Poder e o Dever ${ }^{213}$ de fixar o sentido de uma norma jurídica e aplicá-la ao caso concreto de forma efetiva.

No caso brasileiro, o arbitramento do sentido de uma norma e sua aplicação coativa caberá a um magistrado, legalmente investido no cargo, e sorteado, de forma aleatória, pelo programa de um computador. Podemos dizer que a direção da norma, fixada por esse magistrado sorteado pelo programa do computador ou por algum Regimento Interno do Poder Judiciário, vai exercer, simbolicamente, uma violência, substituindo o papel da força e da violência concreta pela violência do direito, domesticada e aceita pela sociedade. Nesse sentido, podemos concluir que a positividade de uma norma, assim como a positividade de uma interpretação estão ligadas sempre a uma graduação de poder. Direito e Poder são as duas faces da mesma moeda.

Sucede que, no Brasil, qualificado como Estado de Direito, não existem juízes de coisas externas ao reino da $l^{2} i^{214}$. A imperatividade do Direito impõe-se ao julgador para preservação dos valores da segurança e da certeza, componentes relevantes do viver social. ${ }^{215}$ Assim, as valorações do magistrado passam a pertencer ao mundo do Direito não pelo fato de serem boas, sábias ou justas, mas simplesmente por derivarem de regras válidas do sistema jurídico ${ }^{.216}$

Embora a Constituição de 1988, na qual se encontram positivados os direitos humanos sociais, seja prolixa e traga em seu bojo a consagração de interesses díspares, e ainda que exista certa vagueza em alguns termos ou expressões linguísticas, as normas constitucionais que os garantem encontram-se expressos em um texto claro ${ }^{217}$, inseridos em um contexto axiológico que precisa ser identificado e assegurado pelo magistrado, a quem cabe decidir a controvérsia de forma pacífica, com a máxima realização possível do Direito.

\footnotetext{
${ }^{213} \mathrm{~V}$. nota 21.

${ }^{214}$ ARENDT, Hannah. Eichmann em Jerusalém: um relato sobre a banalidade do mal, cit., p. 276.

${ }^{215}$ REALE, Miguel. Estudos de filosofia e ciência do direito, cit., p. 134.

${ }^{216}$ BARBOSA, Alaor. op. cit.

${ }^{217}$ NEVES, António Castanheira. op. cit., p. 11-44.
} 
No que diz respeito aos direitos humanos, podemos dizer que a entropia do sistema normativo, como relatado, faz com que o sentido da mensagem, impregnada de informações propagadas ao mesmo tempo, circule cheio de ruídos pelo ordenamento jurídico e, nesse contexto, o magistrado-intérprete não consiga decifrá-la e processá-la rapidamente.

Para cumprir difícil tarefa, o magistrado deveria voar, ao mesmo tempo, como Hermes, mediador universal, grande comunicador, psicopompo, através do ordenamento jurídico e das expectativas sociais em conflito, ocupando o vazio entre elas, assegurando o trânsito de umas às outras.Sempre em movimento, Hermes pode estar, ao mesmo tempo no céu, sobre a terra e nos infernos. Deus dos mercadores, preside os intercâmbios; conecta os vivos e os mortos; deus dos navegantes, supera travessias desconhecidas. Rápido. Desportivo.

Ocorre que existem diferenças entre os magistrados brasileiros e Hermes. Ele era o arauto dos deuses do Olimpo; o mais habilidoso dos filhos de Zeus. Conhecia a lei da circulação dos discursos. Versátil, astuto, veloz. Sempre muito animado, gostava de pregar peça nos outros. Furtou a aljava de Eros, o tridente de Posêidon, a lança de Ares e as tenazes de Hefesto. Sumiu com o cetro de ouro de Zeus. Quando adulto, tornou-se bem comportado e ganhou a confiança de Zeus, tornando-se mensageiro do Olimpo. Muito persuasivo, era o deus da eloquência. ${ }^{218}$ Não bastassem todas essas aptidões, ainda teve muita sorte, pois foi o único dos filhos de Zeus, que não era de Hera, do qual ela gostou, porque ficou impressionada com a sua inteligência.

Os magistrados brasileiros, no entanto, não são filhos de Zeus ou deuses do Olimpo, mas sim filhos da era tecnológica, das pílulas milagrosas ${ }^{219}$. Confiam, em sua condição de homo faber $^{220}$, no saber tecnológico, na instrumentalização do mundo, nas

\footnotetext{
${ }^{218}$ FERON, José. As mais belas lendas da mitologia. Tradução de Monica Stahel. São Paulo: Martins Fontes, 2000. p. 172-174.

${ }^{219}$ SANTOS, Mario Ferreira dos. op. cit., p. 27.

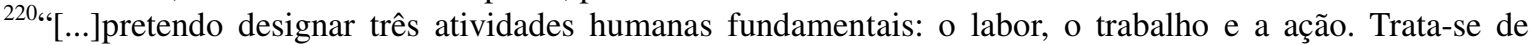
atividades fundamentais porque a cada uma delas corresponde uma das condições básicas mediante as quais a vida foi dada ao homem na Terra. O labor é a atividade que corresponde ao processo biológico do corpo humano, cujos crescimentos espontâneo, metabolismo e eventual declínio têm a ver com as necessidades vitais produzidas e introduzidas pelo labor no processo da vida. A condição humana do labor é a própria vida.O trabalho é a atividade que corresponde ao artificialismo da existência humana, existência esta não necessariamente contida no eterno ciclo vital da espécie, e cuja mortalidade não é compensada por este último. O trabalho produz um mundo artificial de coisas, nitidamente diferente de qualquer ambiente natural. Dentro de suas fronteiras habita cada vida individual, embora esse mundo se destine a sobreviver e a transcender todas as vidas individuais. A condição humana do trabalho é a mundanidade. A ação, única atividade que se exerce diretamente entre os homens sem a mediação das coisas ou da matéria, corresponde
} 
ferramentas e na produtividade do fazedor de objetos artificiais. Acreditam no caráter global da categoria de meios e fins e têm a convicção de que qualquer assunto pode ser resolvido e qualquer motivação humana, reduzida no princípio da utilidade. Nesse contexto, o conhecimento deve ser apresentar como de fácil apropriação, marcado sempre por uma influência econômica de custo-benefício. Em face do frenético ritmo da vida moderna, não dispõe do tempo de que dispunham os antigos para dedicarem-se a um estudo mais apurado dos métodos de raciocinar e refletir.

Nesse cenário, a função judicante vem se tornando cada vez mais burocrática, transformando os juízes em meros agentes do poder público, engrenagens necessária à produção de decisões, desumanizando-os ${ }^{221}$. Poucos magistrados apresentam a versatilidade, a criatividade e a improvisação de Hermes.

A análise dos casos concretos demonstrou que há magistrados que se apresentam como burocratas e fetichistas da jurisprudência, ajoelhando-se diante dos repertórios jurisprudenciais como se fossem livros sagrados de alguma religião cabalística $^{222}$. Contra a evidência do erro, antepõem-se, enfileirados cronologicamente, uma dúzia ou mais de acórdãos ${ }^{223}$. Há os teóricos, que aplicam um direito cerebrino e inumano, como ciência de lógica pura, divorciado da realidade humana. Há os apriorísticos, que constroem, em seu espírito, uma parede de apriorismos e preconceitos jurídicos. Há os que só se preocupam com a repercussão de seus atos e se inspiram no servilismo em face dos governantes ou da opinião pública. Há os que são motivados pela covardia, pelas paixões de momento ${ }^{224}$. Há os que se assemelham ao juiz Hércules de Dworkin; juiz racional, que leva os direitos fundamentais a sério, que domina o império do Direito e consegue encontrar, em todas as ocasiões, a resposta correta. Há os que entendem que as regras gerais e normativas são simples possibilidades jurídicas, não obrigatórias, podendo dar-lhes consistência, ou não, em suas decisões particulares em face do caso

à condição humana da pluralidade, ao fato de que homens, e não o Homem, vivem na Terra e habitam o mundo. Todos os aspectos da condição humana têm alguma relação com a política; mas esta pluralidade é especificamente $a$ condição - não apenas a conditio sine qua non, mas a conditio per quam -de toda vida política. (ARENDT, Hannah. A condição humana, cit., p. 318).

${ }^{221}$ ARENDT, Hannah. Eichmann em Jerusalém: um relato sobre a banalidade do mal, cit., p. 312, 313: "Quando Hitler disse que viria o dia em que na Alemanha se consideraria uma 'desgraça' ser jurista, ele estava falando com absoluta coerência de seu sonho de uma burocracia perfeita."

${ }^{222}$ HUNGRIA, Nelson. op. cit., v. 1, t. 1, p. 60-66.

${ }^{223}$ Id. Ibid.

${ }^{224}$ Id. Ibid. 
concreto. Há os bem intencionados, que procuram seguir pelos caminhos mais seguros com o objetivo de achar as melhores soluções. ${ }^{225}$

Contudo, diferentemente de Hermes, impregnando-se de doutrina e jurisprudência, a maior parte dos juízes se despersonaliza, impregnando-se de apriorismos, fecha os olhos para a vida; à força de querer se apresentar só desta ou daquela forma, perde a espontaneidade, a crença em si mesmo e a coragem de pensar por conta própria ${ }^{226}$. E mais: despreza o dom da improvisação.

Podemos dizer que os magistrados brasileiros, uns mais e outros menos, apresentam algumas dessas características isoladas ou combinadas e, manejando-as da forma que sabem, lidam com os conflitos que se lhes apresentem.

\subsection{O ambiente}

A interpretação do Direito, com vistas à fixação do sentido da norma e sua aplicação pelo magistrado, aparece em meio a um procedimento processual, em um jogo dialético e público, oportunidade em que precisa ser assegurado o lugar da controvérsia, da contestação, da defesa, da dissidência, a fim de que possa haver, em primeiro lugar, a compreensão do fato e do Direito.

Muito bem. Podemos dizer que a dialética é a arte de esclarecer, descobrir a verdade através das idéias. E dizemos esclarecer, porque a alétheia, a verdade dos gregos, que não se confunde com o nosso conceito de verdade, significava a iluminação, o clareamento, o iluminar que está em trevas. E como o espírito (nous) tem a razão (logos), era através desta (diá), que a luz poderia surgir, dissipando trevas.

A dialética coloca as partes em posições diferentes, em pontos opostos, trabalhando entre a luz e as trevas, entre opiniões boas e más, sopesando valores e opiniões, no correr de um diálogo, em que as partes enfrentam opiniões diversas para, por meio delas, esclarecer. A Dialética é, assim, a arte de esclarecer por meio de idéias ${ }^{227}$.

No curso desse processo, obrigatoriamente dialético, aflui o que poderíamos chamar de uma rodada hermenêutica. E é, justamente, nessa rodada que deve ocorrer a

\footnotetext{
${ }^{225}$ SANTOS, Mario Ferreira dos. op. cit., p. 17.

${ }^{226}$ HUNGRIA, Nelson. op. cit., v. 1, t. 1, 60-66.

${ }^{227}$ SANTOS, Mario Ferreira dos. op. cit., p. 27.
} 
compreensão da norma jurídica com vistas ao arbitramento de seu sentido, bem como à compreensão e fixação do fato e de sua qualificação jurídica. Como adverte Gadamer, a arte de interpretar envolve compreensão, que só pode sobrevir quando nos propomos, não apenas a ouvir, mas, realmente, a escutar um ao outro, porque texto é linguagem e linguagem é um "nós" e não um "eu” singular. ${ }^{228}$

Direito é linguagem, e a sua interpetação não se subordina ao despotismo do caminho de mão única de uma só verdade ${ }^{229}$. Como anota Wittgenstein, não há língua privativa. Qualquer um que fale uma língua que ninguém mais fale, não está realmente falando porque linguagem não é um processo designado por um sujeito individualmente. Linguagem é um nós. Isso significa que todos precisamos ultrapassar nossos limites de compreensão para compreender. Conviver em uma comunidade é conviver junto em uma mesma linguagem, e a linguagem existe somente no diálogo. ${ }^{230}$ Especialmente por esta razão, a Comissão e a Corte Europeia de Direitos Humanos têm privilegiado, sistematicamente, entre todos os direitos fundamentais do Tratado dos quais têm custódia, o sexto, que se ocupa das garantias do processo equitativo, única forma de preservação de um jogo realmente dialético. Nesse sentido, também a nossa Constituição positivou o princípio do devido processo legal, da paridade de armas, indispensável à concreta atuação do contraditório e à própria imparcialidade do juiz. ${ }^{231}$

Concluímos que o procedimento estabelecido no curso de uma relação processual equitativa corresponde à instituição da virtude da prudência: tempo e espaço para reflexão, para a fixação de um "nós".

\footnotetext{
${ }^{228}$ GADAMER, Hans-Georg. Gadamer in conversation: reflections and commentary, cit., p. 39.

${ }^{229}$ ARENDT, Hannah. The recovery of the public world. Edited by Melvyn A. Hill. New York: St. Martin's Press, 1979. p. 317.

${ }^{230}$ GADAMER, Hans-Georg. Gadamer in conversation: reflections and commentary, cit., p. 56 " There is no private language. Whoever speaks a language that nobody else understands is not really speaking. Language is not something assigned by individual human subjects. Language is a we, in that we are assigned our place in relation to each other, and in which the individual has no fixed borders. This means, however, that we all must overstep our own personal boarders/limits of understanding in order to understand. This is what happens in the living exchange of conversation. All living together in a community is living together in language, and language exists only in conversation".

${ }^{231}$ GRINOVER, Ada Pellegrini. op. cit., p. 15.
} 


\title{
5.4. A compreensão do direito
}

\author{
Perguntaram, um dia, a Uwais, o Sufi ${ }^{232}$ : \\ "Que inspiração lhe trouxe a Graça?". \\ E eis o que respondeu: \\ "Cada manhã, ao despertar, me sinto \\ como alguém que não tem certeza alguma de chegar vivo à tarde”. \\ Perguntaram-lhe, ainda: \\ "Mas, afinal, não sabem disso todos?". \\ E ele, de novo: "Saber sabem-no todos, certamente, \\ mas são poucos os que o sentem!”. \\ Ninguém jamais se embebedou apenas do \\ conhecimento intelectual da palavra VINHO. ${ }^{233}$
}

O juiz deve ouvir e sentir o Direito para compreendê-lo. No entanto, essa não é uma tarefa que se aprende ou que se ensine com facilidade. Exige propriocepção ${ }^{234}$, muito exercício e experiência.

John Searle, filósofo norte-americano, argumenta, com precisão, que a simples execução de um programa correto não gera compreensão. Vamos trazer o exemplo do Quarto Chinês, argumento hipotético criado por ele, para ilustrar a questão ${ }^{235}$.

Imaginemos um sistema de informática montado da seguinte maneira:

1. CPU, unidade central de processamento: o juiz;

2. Software, inteligência artificial: legislação, repertórios de jurisprudência e livros de doutrina;

O juiz, unidade central de processamento, está em seu gabinete, com a porta fechada, mas com uma pequena passagem para o exterior. Por essa abertura, entram os casos concretos a serem decididos, aparentemente indecifráveis.

\footnotetext{
${ }^{232}$ Designação dada no Ocidente ao rei da Pérsia.

${ }^{233}$ MELLO, Anthony. op. cit.

234،"Proprioception: The ability to sense stimuli arising within the body. Even if you are blindfolded, you know through proprioception if your arm is above your head or hanging by your side. The word "proprioception" was coined in 1906 by the English neurophysiologist Charles Sherrington who received the Nobel Prize for Physiology or Medicine in 1932 for research on the function of the neuron and study of reflex action." (MEDICAL Dictionary. Disponível em: $<$ http://www.medterms.com/script/main/art.asp?articlekey=6393>. Acesso em: 19 jul. 2009).

${ }^{235}$ Cf. SEARLE, John. Minds, brains, and programs. Behavioral and Brain Sciences, n. 3, p. 417-442, 1980.
} 
O juiz encontra, nas pilhas jurisprudência, nos livros de doutrina e nos Vademecum, os símbolos correspondentes indecifráveis correspondentes e, decifrando-os, decide os casos concretos. Do exterior, percebemos um sistema que está recebendo a entrada de fatos e gerando respostas jurídicas- decisões judiciais, que são, sem dúvida inteligentes.

Mas o juiz não compreende os fatos. Os livros de regras e de doutrina não alcançam os fatos e sua complexidade. Então, não está acontecendo nenhuma compreensão do Direito e dos fatos, embora o programa esteja sendo corretamente executado. Dessa forma, podemos concluir que a simples execução do programa correto, sem percepção ou “propriocepção" não gera compreensão.

Como falava Nelson Hungria, "O juiz deve ter alguma coisa de pelicano. A vida é a variedade infinita e nunca lhe assentam com irrepreensível justeza as "roupas feitas" da lei e os figurinos da doutrina. Se o juiz não dá de si, para dizer o direito em face da diversidade de cada caso, a sua justiça será a do leito do Procusto: ao invés de medir-se com os fatos, estes é que terão de medir-se com ela., 236

Ocorre que os magistrados não devem ser; como quer Nelson Hungria. Eles são o que são e, cada um a sua forma, deverá decidir os casos concretos a eles endereçados. É importante perceber, na análise dessa matéria, que um caso mais delicado não será, obrigatoriamente, endereçado a um juiz mais sensível, experiente ou com maior compreensão do Direito. Além da Constituição Federal, há leis e atos administrativos internos do Poder Judiciário fixando, de forma expressa, a competência dos magistrados, de sorte que os casos concretos são encaminhados de forma aleatória, pouco importando o grau de experiência, de sensibilidade ou de compreensão do magistrado acerca desta ou daquela matéria.

\subsection{Análise dos casos concretos}

Embora a ninguém surpreenda a supremacia da Constituição, o fato é que a convivência efetiva da normativa constitucional é algo cuja tecnologia parece estar em construção, porque percebemos que o magistrado nem sempre fixa os princípios

\footnotetext{
${ }^{236}$ HUNGRIA, Nelson. op. cit., v. 1, t. 1, p. 63.
} 
constitucionais como princípio de seu raciocínio e o raciocínio como princípio de seu trabalho.

A análise dos casos concretos demonstra que os princípios constitucionais deixam de ser aplicados em primeiro lugar, figurando apenas de forma residual na interpretação da norma. Observamos, de forma simplificada, a existência de dois tipos básicos de raciocínio: aquele cuja premissa maior é o princípio constitucional e a premissa menor encontrada à luz desse princípio e aquele cuja premissa maior é a legislação infraconstitucional ou algum fato externo (clamor público, por exemplo) e a premissa menor é dele decorrente.

Parece que a própria incidência direta da Constituição sobre as relações Estado-particulares abre, operacionalmente, um campo fértil de dúvidas, quer pela ausência de tradição dos magistrados no manejo das normas constitucionais, quer porque todo princípio constitucional é um valor positivado pela sociedade e, como tal, precisa passar do mundo ideal para o mundo real pela ação do magistrado.

Sucede que se apreendemos o ser por meio da inteligência (mesa, cadeira, casa, etc.), apreendemos o valor (belo, ruim, bom, mau, dignidade da pessoa humana, presunção de inocência, etc.) por meio de uma particular forma de sentir espiritual; por essa razão, a aplicação do princípio é sempre mais difícil para o juiz. ${ }^{237}$

Fica, assim, uma sensação empírica, de que não obstante seu caráter dogmático, existe certa vacilação do magistrado em aplicar um princípio constitucional que ele já não tenha incorporado em sua cultura de alguma forma, principalmente em virtude do seu eventual impacto na solução do caso concreto. Como exemplo, podemos citar a garantia do direito à saúde em ações individuais e o deferimento do benefício assistencial em casos individuais em contraste com as ações coletivas.

Nesse contexto, ele recorre, habilmente, ao teor semântico aberto dos princípios constitucionais e à possibilidade de certa graduação na sua realização para afastar ou reduzir a força do princípio, vulnerando a certeza e a previsibilidade, como elementos-chave do sistema jurídico.

Observamos, contudo, a facilidade no manuseio do princípio da legalidade: o magistrado o aplica com segurança, não temendo o seu impacto na solução do caso concreto. Empiricamente, percebemos que esse princípio, por ser qualificado como

\footnotetext{
${ }^{237}$ HESSEN, Johannes. op. cit.
} 
invariante axiológica, já se encontra incorporado internamente no sentir do magistrado, de sorte que a ele se curva com facilidade. Como exemplo, poderemos citar o HC 34.987-RJ, e a Apelação Criminal 19059-SP.

Esse dado, encontrado quase que por acaso em nossos estudos, parece-nos extremamente importante: toda concepção do Direito implica, necessariamente, uma concepção de seus princípios e o sentido desses princípios reside, precisamente, na realização dos valores neles objetivados. Logo, os princípios constitucionais são valores positivados, que ingressam no ordenamento jurídico, mas nem por isso perdem a característica ínsita de valor, mas dado o seu caráter deontológico são de ser de aplicação obrigatória para o magistrado, que passa a flexibilizá-lo também em função da sua não internalização. Como exemplo, poderemos citar a ADIN 1232 (princípio da dignidade da pessoa humana), HC 56.975-PA (princípio da inocência), HC 783-427- DF (princípio da igualdade), HC 44.165-RS (presunção da inocência e dignidade da pessoa humana).

\section{6. $O$ valor}

O conceito de valor não pode rigorosamente definir-se. Pertence ao número daqueles conceitos supremos, como os de ser, existência, que não admitem definição. ${ }^{238}$

Quando pronunciamos a palavra valor, podemos com ela querer significar três coisas distintas: a vivência de um valor, a qualidade de uma coisa, ou a própria idéia de valor em si mesma. Cada uma delas apreende apenas uma faceta do fenômeno valor. Está também ínsito ao conceito de valor, o conceito de relação com um certo sujeito. ${ }^{239}$

Contudo, não se deve pensar, com essa relação, que no domínio dos valores possa ser o sujeito, isto é, o indivíduo valorante quem decidirá o que é valioso e não valioso, muito menos no Direito, em que determinados valores já foram positivados e são de aplicação obrigatória para o juiz. O sujeito não é a medida dos valores. Não se deve pensar que os valores e juízos de valor só valham para este ou para aquele sujeito ou indivíduo que tenham a percepção deles, e não para os outros. ${ }^{240}$ Eles valem e são

\footnotetext{
${ }^{238}$ HESSEN, Johannes. op. cit.

${ }^{239}$ Id. Ibid.

${ }^{240}$ Id. Ibid.
} 
obrigatórios para todos os magistrados, mas uns os manejam com mais facilidade do que outros em função da experiência e da vivência desses mesmos valores.

O mundo particular dos objetos ideais, como os valores, os objetos lógicos e a matemática, está sempre referido a um sujeito, isto é, existe pelo espírito e para o espírito. Podemos considerar certas idéias de valor, como a justiça, a beleza como essências ideais do ser, e compará-las com as grandezas matemáticas, porém não podemos esquecer que todo esse mundo de objetos ideais não existiria se não existisse o espírito. ${ }^{241}$

Os valores podem tornar-se realidade. Uma obra científica, uma obra de arte, uma ação moral representam realizações de valores. Toda cultura é isto; a Cultura humana é, na sua íntima essência, uma realização de valores. ${ }^{242}$

Examinemos mais de perto o fenômeno da realização de valores. Os valores começam por ser algo ideal, por pertencer a uma esfera de ser ideal e penetram, num certo momento, na esfera do real. Assim, um valor estético converte-se em existencial no quadro do pintor; o valor ético, na ação do homem virtuoso, e o princípio constitucional, na decisão do juiz. Os valores não possuem um ser independente, mas são de certo modo, trazidos, sustentados pelas coisas nas quais se realizam. As coisas são, então, portadoras de valores $^{243}$.

A evidência também demonstra que a ordem do valioso é uma ordem à parte, bem distinta da do ser. E a primeira coisa que salta à vista é esta: as coisas portadoras dos valores acham-se situadas na ordem temporal. São, portanto, mutáveis, transitórias, efêmeras. O homem bom pode mudar sua personalidade e transformar-se em uma pessoa má, o quadro pode ser destruído e as suas qualidades de beleza desaparecerem; no entanto, é curioso notar que, mesmo quando isso se dá, as modificações produzidas no suporte dos valores não afetam estes. Os valores não se alteram com a alteração dos objetos em que se manifestam. O valor da amizade não sofre quebra porque um amigo nos traiu. É por isso que os valores se nos dão como imutáveis e permanentes. ${ }^{244}$

Os valores admitem graus; são susceptíveis de mais ou menos. Por exemplo, o valor da beleza pode atingir na sua realização diversos graus, o mesmo acontecendo com um princípio constitucional. E não é só isso: a mesma ordem hierárquica se encontra na

\footnotetext{
${ }^{241}$ HESSEN, Johannes. op. cit.

${ }^{242}$ Id. Ibid.

${ }^{243}$ Id. Ibid.

${ }^{244}$ Id. Ibid.
} 
relação dos valores uns para com os outros. Há valores que são mais altos que os outros, como acontece com o princípio da dignidade humana. Essa estrutura hierárquica é desconhecida dentro da ordem do ser. Não podemos afirmar que qualquer ser possua mais ser que o outro, ou seja, mais real que o outro ${ }^{245}$.

\subsection{Expectativas sociais}

Percebemos que o Direito atual é o Direito do heterogêneo e do plural. A heterogeneidade está na Constituição, como resultado multiforme de tendências díspares; a heterogeneidade está nos valores, nem sempre conciliáveis, a exigir ponderação; a heterogeneidade está nas fontes normativas, a heterogeneidade está nos sujeitos de direito, que deixaram de ser uma figura uniforme para assumir a condição de uma pluralidade concreta: consumidor, possuidor, contratante, doente, idoso, estudante, criança - todos merecendo uma proteção diferenciada e a heterogeneidade está no perfil pessoal de cada magistrado, que figura como árbitro do sentido da norma.

Nesse contexto, a expectativa de nossa sociedade é que a decisão judicial funcione como elemento dinâmico e organizador de um sistema heterogêneo, em estado de entropia, dando início ao processo dinâmico de aplicação do Direito, retirando-o, como bálsamo, das brumas da confusão.

Organizemo-nos da melhor maneira, em conformidade com o que já temos. Nada de criar um Direito novo ou viajarmos até o Olimpo atrás de Hermes. Uma sociedade só descansa em paz quando assume as responsabilidades pelas quais, consensualmente, obrigou-se. E Hermes não estava aqui quando foi promulgada a Constituição de 1988. Nós assumimos essa responsabilidade coletivamente e devemos fazer nosso trabalho.

\subsection{Um pequeno ajuste}

O magistrado não precisa se transformar, da noite para o dia, em Hermes ou em um artista do Cirque Du Soleil, e praticar os malabarismos e as acrobacias que o

\footnotetext{
${ }^{245}$ HESSEN, Johannes. op. cit.
} 
ordenamento jurídico está exigindo. Vamos começar sugerindo um pequeno ajuste que ajude a organização do trabalho.

Como falamos no início, a intenção de nossos estudos é sugerir apenas uma pequena intervenção ou um pequeno ajuste nos limites que o tema permite. ${ }^{246}$

Para exemplificar a proposta, usemos uma metáfora. Vamos apenas nos sentar, como tantas vezes o fazemos, mas, com uma pequena adaptação. Não mais nos sentemos de qualquer jeito, mas em cima de nossos ísquios, de maneira a organizar a nossa coluna e desenvolver a propriocepção.

Tentemos abandonar a visão consumista de que tudo precisa de ser sempre descartado e renovado, de que devemos, sem cessar, jogar as coisas fora e adquirir outras tantas para nos aprimorarmos. Pequenos ajustes, na maioria das vezes, são suficientes. Retornemos à antiga prática de pensar e refletir.

Muito bem. Sabemos que face às múltiplas possibilidades interpretativas decorrentes das mensagens armazenadas no banco de dados de nosso ordenamento jurídico, deverá o magistrado procurar um sentido que prepondere, captando, nesse propósito, o sentido da lei.

Imaginando o sistema escalonado de nosso ordenamento jurídico escalonado (em formato de pirâmide), para usar o exemplo de Kelsen, temos a sensação que a visão de cima da pirâmide, no topo do ordenamento jurídico escalonado, vai privilegiar a figura do legislador, pondo sua vontade em relevo, traduzindo as exigências subjetivistas do Estado liberal ou Estado de Direito do século XIX.

A visão da base da pirâmide visualizará o juiz na posição de relevo, deslocando para ele a responsabilidade do legislador, ao traduzir as necessidades das atividades do Estado assistencial do século XX. Nessa perspectiva, é a decisão e não a lei que cria autoridade. $\mathrm{O}$ código, então, passa a ser substituído pela singularidade do caso concreto. Dir-se-á que não há mais Direito do que o jurisprudencial. ${ }^{247}$

Contudo, todas essas posições podem proporcionar um olhar míope tanto da perspectiva do Direito quanto da perspectiva do conflito, como qualquer posição extremada. A que prestigia só a vontade do legislador favoreceu certo autoritarismo, como

\footnotetext{
${ }^{246}$ BAGGINI, Julian. Making sense, philosophy behind the headlines. Oxford: Oxford University Press, 2002. p. 287.

${ }^{24}$ FERRAZ JUNIOR, Tércio Sampaio. Função social da dogmática jurídica. São Paulo: Max Limonad, 1998. p. 143.
} 
aconteceu na época do nazismo; a que prestigia só os fatos, favoreceu certo anarquismo $^{248}$ Porém, cabe aqui uma importante ressalva. $\mathrm{Na}$ fase juspositivista dos séculos XIX e XX, os princípios entravam nos Códigos como fonte subsidiária da inteireza dos textos legais e não eram encarados como superiores às leis, mas delas deduzidos para suprirem os vazios normativos que elas não puderam prever. $\mathrm{O}$ valor dos princípios estava no fato de derivarem das leis e não de um ideal de justiça. Atualmente, os princípios, positivados nos textos constitucionais, apresentam-se como normas jurídicas vinculantes, vigentes e eficazes e assentam os principais padrões pelos quais se investiga a compatibilidade da ordem jurídica à Constituição, pois dão o fundamento axiológico normativo do ordenamento jurídico. ${ }^{249}$ Nessa perspectiva, parece-nos que a aplicação dos princípios constitucionais, da forma como colocados na Constituição Federal, limita as valorações arbitrárias dos magistrados, levadas pela emoção e pela violência (princípio do devido processo legal, princípio da presunção da inocência, princípio da dignidade da pessoa humana, etc.), impondo a observação dos valores consensualmente aceitos pela sociedade.

Nesse contexto, o magistrado poderá continuar a sentar em cima da pirâmide, não mais para prestigiar a vontade do legislador, mas os valores da sociedade instrumentalizados em princípios constitucionais e perceber o ordenamento jurídico por meio desses valores, dado o seu caráter deontológico. E a partir desses princípios, deverá visualizar as leis aplicáveis, bem como a qualificação jurídica do fato. O princípio passará a ser a lente através da qual o magistrado enxergará o ordenamento jurídico e qualificará juridicamente o fato.

Contudo, como o juiz não é Hermes, o arauto dos Deuses, e tampouco um acrobata do Cirque du Soleil, mas apenas alguém dos tempos modernos, para bem cumprir essa tarefa precisa observar, com atenção, o jogo dialético que o próprio sistema jurídico estabelece, e no qual ele aparece como árbitro.

Recordemos, nesse passo, que o procedimento processual (jogo dialético) é justamente a institucionalização da prudência, um tempo para reflexão. E, no curso desse processo, obrigatoriamente dialético, ocorre uma rodada hermenêutica. E é, justamente, essa rodada dialética, que gerará a compreensão da norma jurídica com vistas ao

\footnotetext{
${ }^{248}$ FERRAZ JUNIOR, Tércio Sampaio. Função social da dogmática jurídica, cit.

${ }^{249}$ BARROSO, Luis Roberto; BARCELLOS, Ana Paula. op. cit.
} 
arbitramento de seu sentido, bem como à compreensão e fixação do fato e de sua qualificação jurídica.

Contudo, embora o raciocínio dialético leve à compreensão, não é sempre um raciocínio conclusivo, como deve ser a decisão judicial. Assim, sugerimos que os magistrados utilizem o antigo modo lógico-subsuntivo de pensar, tanto para fixar as premissas do raciocínio como para concluí-lo, até mesmo porque os juristas, como já observou alguém, "só se movem à vontade nos programas condicionais, mesmo quando repudiam o credo 'lógico-subsuntivo' do positivismo" 250 . Ademais, a análise dos casos concretos demonstrou que os magistrados já os utilizam de uma forma ou de outra. Esta proposta não implica na redução do processo decisório a um silogismo, mas sim na afirmação que ele é um instrumento útil para organização do pensamento.

São oito as regras do silogismo ${ }^{251}$ :

1- O silogismo tem três termos: o maior, o médio e o menor. Tal é necessário para fazer a comparação dos dois com um terceiro. $\mathrm{O}$ silogismo tem três termos: o maior, o médio e o menor. Esses termos são os que entram nos juízos ou proposições que constituem o silogismo. O predicado da conclusão recebe o nome de termo maior. $\mathrm{O}$ sujeito da conclusão é chamado de termo menor. O termo médio é o que estando presente nas duas premissas, falta na conclusão.

2- A conclusão nunca deve conter o termo médio.

3- O termo médio deve ser tomado, pelo menos uma vez, em toda a sua extensão. Sim, porque o termo médio serve para comparar os extremos, e, na conclusão, deve aparecer o resultado, ou seja, a relação dos extremos entre si.

4- Nenhum termo pode ser mais extenso nas conclusões do que na premissa.

5- Se as duas premissas são negativas, nada se pode concluir.

6- Duas premissas afirmativas não podem produzir uma conclusão negativa.

7- A conclusão segue sempre a parte mais fraca. Chama-se a mais fraca a premissa particular ou negativa.

\footnotetext{
${ }^{250}$ CANOTILHO, José Joaquim Gomes. Constituição dirigente e vinculação do legislador: contributo para a compreensão das normas constitucionais programáticas. Coimbra: Coimbra Ed., 1994. p. 367.

${ }^{251}$ SANTOS, Mario Ferreira dos. op. cit.
} 
8- Nada se conclui de duas premissas particulares.

Nesse sentido, sugerimos como método de raciocínio decisório ou como método de justificação da decisão judicial a sequência de raciocínio três silogismos, sempre considerando os princípios constitucionais evidência que dispensa justificação:

\section{SILOGISMO I:}

Considerando-se o princípio constitucional aplicado na maior graduação possível (premissa maior) e a legislação infraconstitucional (premissa menor), então definimos a norma aplicável (conclusão I).

\section{SILOGISMO II:}

Considerando-se o princípio constitucional aplicado na maior graduação possível (premissa maior) e o fato (premissa menor), então definimos a qualificação jurídica do fato (conclusão II).

\section{SILOGISMO III:}

Tendo-se definido a Norma aplicável [conclusão I] (premissa maior) e a qualificação jurídica do fato [conclusão II] (premissa menor), então justifica-se a decisão judicial (conclusão III) .

Como disse M. Scheler ${ }^{252}$, a filosofia tem pagado até hoje um largo tributo a um preconceito que se acha radicado numa antiga e muito conhecida maneira de pensar. Consiste este preconceito na tendência, em absoluto estranha à estrutura de nosso espírito, para separar totalmente a razão da sensibilidade. Deve haver sensibilidade na lógica, até mesmo para achar as premissas.

Podemos dizer que o processo decisório envolve um ato de apreensão, a formação de um juízo e depois um raciocínio. A definição clássica de raciocínio é dada por

\footnotetext{
${ }^{252}$ HESSEN, Johannes. op. cit., p. 149.
} 
Aristóteles. O raciocínio é um argumento em que, estabelecidas certas coisas, outras coisas diferentes se deduzem necessariamente das primeiras. O raciocínio é uma demonstração, quando as premissas das quais parte são verdadeiras e primeiras, ou quando o conhecimento que delas temos provém originariamente de premissas primeiras e verdadeiras: e, por outro lado, o raciocínio é dialético quando parte de opiniões geralmente aceitas. São verdadeiras e primeiras aquelas coisas nas quais acreditamos em virtude de nenhuma outra coisa que não elas próprias; pois, no tocante aos primeiros princípios da ciência, é descabido buscar mais além o porquê e as razões dos mesmos; cada um dos primeiros princípios deve impor a convicção da sua verdade um si mesmo e por si mesmo. São, por outro lado, opiniões geralmente aceitas aquelas que todo mundo admite, ou a maioria das pessoas, ou os filósofos - em outras palavras: todos, a maioria ou os mais notáveis e eminentes. ${ }^{253}$

A importância da aplicação do silogismo ao Direito surge apenas com a modernidade e o sucesso do positivismo científico, havendo sido seu uso defendido pelos iluministas do século XVIII, em face da preocupação com a justa e segura aplicação das normas $^{254}$. Na atualidade, apresenta-se necessário não só em face da preservação do valor segurança, como também de outros já positivados na Constituição Federal.

Que o silogismo não é a forma natural do nosso raciocinar e não compreende toda complexidade do processo decisório, nós bem o sabemos. Contudo, não podemos desprezá-lo por isso, porque ainda é um modo seguro de evitar erros. Se o magistrado raciocinar silogisticamente, facilmente verificará seus erros e suas virtudes. Raciocinar dessa maneira exige paciência, devoção, esmero e disciplina. É inegável que, no proceder do raciocínio, surgem inúmeras ocasiões em que o pensamento não só vacila como claudica, a ponto de erros se apresentarem como verdades definitivas. $\mathrm{O}$ aspecto subjetivo da evidência, que se firma na convicção, na adesão firme de nosso espírito sem vacilação, termina, em face do suceder dos fatos ou do próprio raciocínio, revelando que aquela verdade ocultava um grande erro. ${ }^{255}$

O silogismo é uma argumentação lógica. A Lógica é uma reunião coordenada das regras e normas alcançadas, justificadas pela experiência. Os estudos de lógica promovidos por Aristóteles tiveram grande poder de influência durante toda a Idade

\footnotetext{
${ }^{253}$ ARISTÓTELES. Tópicos, cit.

${ }^{254}$ PARINI, Pedro. op. cit.

${ }^{255}$ SANTOS, Mario Ferreira dos. op. cit.
} 
Média, cujo maior expoente é a Escolástica de Tomás de Aquino, que elegeu o direito como um dos objetos mais importantes de suas reflexões. A doutrina aristotélica dos silogismos foi, durante quase dois mil anos, a única fonte informadora da lógica formal. Toda essa perpetuação vem a justificar e valorizar o imenso trabalho que tiveram os grandes filósofos, ao longo dos séculos, para encontrar regras seguras que permitissem um raciocínio isento, tanto quanto possível, de erros. ${ }^{256}$ Acreditamos, assim, que um raciocínio lógico e cuidadoso, vocacionado à identificação das premissas corretas, seria um bom instrumento a serviço do magistrado, funcionando como uma prótese no auxílio da captação das mensagens da norma e na sua valoração.

Bertrand Russell refuta todas as teorias lógicas de Aristóteles falsas, exceto a dos silogismos. Para ele, o que poderia parecer um indício de consistência da lógica aristotélica, diante de seu sucesso por quase dois mil anos, é uma prova de que o momento em que surgem essas teorias seria o declínio da criatividade grega e, consequentemente, uma vitória do argumento de autoridade durante a Idade Média, o que traduziria um período de estagnação no desenvolvimento da lógica. ${ }^{257}$

Ao princípio fundamental do silogismo, princípio da não contradição, também poderia ser oposto o argumento de física quântica conhecido como o gato de Schrödinger, segundo o qual uma entidade poderia ser e não ser ao mesmo tempo. Todavia, esse experimento hipotético se aplica apenas ao mundo quântico e não ao universo macroscópico, onde o Direito se aplica.

Realmente, o silogismo é um raciocínio dedutivo, no qual se comparam dois extremos com um terceiro. Pode em parte ser reduzido ao axioma de que "duas coisas idênticas a uma terceira são idênticas entre si”. Funda-se no princípio da não contradição: “é impossível que uma coisa seja e não seja ao mesmo tempo".

Aristóteles definia-o como "o enunciado no qual, tendo-se proposto algumas coisas, decorre delas, necessariamente, outra coisa, pelo só fato de serem dadas". O silogismo não diz nada mais do que já foi dito, do que está contido numa das premissas, por isso representa uma ferramenta extremamente útil para o magistrado $\mathrm{O}$ silogismo é um raciocínio que vai do geral ao particular, portanto, o que está contido na conclusão já está na premissa. Não oferece nenhum valor inventivo, mas apenas expositivo. ${ }^{258}$

\footnotetext{
${ }^{256}$ SANTOS, Mario Ferreira dos. op. cit.

${ }^{257}$ RUSSELL, Bertrand. op. cit., p. 188-194.

${ }^{258}$ SANTOS, Mario Ferreira dos. op. cit., p. 193.
} 
No raciocínio silogístico, se as premissas são verdadeiras, então o será a conclusão, mas a lógica por si não pode estabelecer ou garantir a verdade das premissas a serem escolhidas pelo magistrado. Como dizia Kant, não há regras para se aprender a aplicar as regras corretamente. ${ }^{259}$ Todavia, se o magistrado escolher o princípio da dignidade humana como a premissa maior nas decisões envolvendo os direitos humanos sociais e analisar e qualificar o fato concreto à luz desse princípio ou desse valor em sua maior graduação, e, a partir daí, escolher a premissa menor, a conclusão, com certeza, atenderá tanto os valores que a Constituição quer assegurar como a expectativa social em conflito.

Ainda, a fixação do princípio constitucional como premissa maior tende a impedir que certos apriorismos ou certos preconceitos possam modelar a realidade mais a nosso sabor do que demonstrar a realidade independente de nós, impondo prudência ao magistrado. Distinguir quando a realidade é a projeção de nossa mente ou quando a realidade é testemunho de si própria é a tarefa mais difícil de ser realizada pelo juiz. Aliás, esse talvez seja o principal motivo pelo qual o valor a ser preservado é sempre aquele previsto na Constituição e não aquele individual ou particular do magistrado.

O raciocínio silogístico ajuda a disciplinar o pensamento e aproveita o padrão que já vem sendo adotado pelos magistrados. Esse trabalho exige esforço, paciência, devoção, esmero e rigorosa disciplina.

Um preconceito moderno é julgar que a Lógica é apenas uma arte prática e até arbitrária. Não há arbitrariedade na Lógica. As leis nela estabelecidas são captadas do rigor das conseqüências e decorrem do rigor dos processos lógicos. Por outro lado, a Lógica não é algo que se opõe à vida. O exame dialético mostra-nos que há uma logicidade na realidade, porque também a vida a revela, que é o nexo de idealidade que há em toda realidade. Outro argumento comum é dizer que ela é estéril. Seria o mesmo que afirmar a esterilidade da Matemática. A Lógica não é criadora enquanto se cinge a seu aspecto formal, que é apenas o instrumento da criação. Mas o exame dialético dos juízos e o desdobramento dos juízos que estavam virtualizados, comprovam que ela é criadora. ${ }^{260}$

Vivemos um tempo em que a burocratização do Poder Judiciário vem desumanizando os magistrados, transformando-os em engrenagens necessárias à produção de sentenças. Dessa forma, passam a perder o dom da prudência e da paciência para sentir

\footnotetext{
${ }^{259}$ GADAMER, Hans-Georg. Gadamer in conversation: reflections and commentary, cit., p. 42.

${ }^{260}$ SANTOS, Mario Ferreira dos. op. cit., p. 200-203.
} 
e compreender o Direito, bem como o dom da criatividade e da improvisação para bem aplicá-lo.

Nesse cenário, no qual figuram a polissemia do sistema jurídico de um lado e a heterogeneidade de seus partícipes, apresentamos o silogismo de princípios como um instrumento adequado, nos limites de intervenção e profundidade que o tema permite, para melhor concretização dos Direitos Humanos sociais. Esse pequeno ajuste aproveita o Direito que possuímos, os magistrados que temos e a técnica de raciocínio que eles já utilizam - de um modo ou de outro - além de constituir uma escolha consciente de espiritualizar o mundo e não mundanizar o espírito.

Com esse pequeno ajuste, teríamos a oportunidade de vivenciar a Constituição Federal, que contém imperfeições, mas apresenta o grande mérito de estar impregnada de valores e de direitos conquistados arduamente ao longo da História. 


\section{REFERÊNCIAS BIBLIOGRÁFICAS}

ALEXY, Robert. Palestra proferida na Fundação Casa de Rui Barbosa. Rio de Janeiro, 10.12.98.

A theory of constitucional rights. Translated by Julian Rivers. Oxford: Oxford University Press, 2004.

ARENDT, Hannah. A condição humana. 10. ed. Tradução de Roberto Raposo Rio de Janeiro: Forense, 2005.

Eichmann em Jerusalém: um relato sobre a banalidade do mal. São Paulo: Companhia das Letras, 2000.

As origens do totalitarismo. Tradução de Roberto Raposo. São Paulo: Companhia das Letras, 2007.

_. The recovery of the public world. Edited by Melvyn A. Hill. New York: St. Martin's Press, 1979.

ARISTÓTELES. Ética a Nicômaco. Trad. de Edson Bini. São Paulo: Edipro, 2002.

. Tópicos. São Paulo: Abril Cultural, 1978. Livro 1. (Os pensadores).

BAGGINI, Julian. Making sense, philosophy behind the headlines. Oxford: Oxford University Press, 2002.

BARBOSA, Alaor. Norberto Bobbio e o positivismo jurídico. Revista de Informação Legislativa, Brasília, ano 25, n. 97, jan./mar. 1988.

BARBOSA, Rui. Tribuna Parlamentar. Casa Rui Barbosa, 1956. v. 5.

BARROSO, Luis Roberto; BARCELLOS, Ana Paula. A nova interpretação constitucional: ponderação, argumentação e papel dos princípios. In: LEITE, George Salomão (Org.). Dos princípios constitucionais: considerações em torno das normas principiológicas da Constituição. São Paulo: Malheiros Ed., 2003. p. 101-135.

BEVILAQUA, Clovis. Criminologia e direito. Bahia: Fonseca Magalhães, 1896.

BOBBIO, Norberto. A era dos direitos. Trad. Regina Lyra. Rio de Janeiro: Campus, 1992. 
BOBBIO, Norberto. Teoria della scienza del diritto. Torino: G. Giappichelli, 1950.

CAMPILONGO, Celso Fernandes. Os desafios do Judiciário: um enquadramento teórico. In: FARIA, José Eduardo (Org.). Direitos humanos, direitos sociais e justiça. São Paulo: Malheiros Ed., 2005.

CANOTILHO, José Joaquim Gomes. Constituição dirigente e vinculação do legislador: contributo para a compreensão das normas constitucionais programáticas. Coimbra: Coimbra Ed., 1994.

Direito constitucional e teoria da Constituição. 2. ed. Coimbra: Almedina, 2001.

CASTRO FILHO, Osvaldo Alves de. A obrigatoriedade da decisão no direito: subsídios para a elaboração de uma teoria da decisão jurídica. Dissertação (Mestrado em Filosofia e Teoria Geral do Direito) - Faculdade de Direito, Universidade de São Paulo, São Paulo, 2007.

COMPARATO, Fabio Konder. A afirmação histórica dos direitos humanos. 3. ed. São Paulo: Brasiliense, 1989.

Juízes independentes ou funcionários públicos. Revista da Associação dos Magistrados Brasileiros, v. 2, n. 4, p. 89-93, jan./jun. 1998.

. Para viver a democracia. São Paulo: Brasiliense, 1989.

CUNHA, Paulo Ferreira da. Anti-Leviatã: direito, política e sagrado. Porto Alegre: Sergio Fabris, 2005.

DALLARI, Dalmo de Abreu. Segurança e direito. In: O renascer do direito: direito e vida social, aplicação do direito, direito e política. 2. ed. São Paulo: Saraiva, 1980. DWORKIN, Ronald. Law's empire. Harvard Cambridge, Massachussets: Harvard University Press, 1988.

ESPÍNDOLA, Ruy Samuel. Conceito de princípios constitucionais. 2. ed. São Paulo: Ed. Revista dos Tribunais, 2002.

FANTONI JÚNIOR, Neyton. Segurança jurídica e interpretação constitucional. Genesis: revista de direito do trabalho, Curitiba, n. 84, p. 809-884, dez. 1999. 
FARIA, José Eduardo. As transformações do Judiciário em face de suas responsabilidades sociais. In: (Org.) Direitos humanos, direitos sociais e justiça. São Paulo: Malheiros Ed., 2005.

FARRALI, Carla. A filosofia contemporânea do direito: temas e desafios. Tradução Candice Premaor Gullo. São Paulo: Martins Fontes, 2006.

FERON, José. As mais belas lendas da mitologia. Tradução de Monica Stahel. São Paulo: Martins Fontes, 2000.

FERRAZ JUNIOR, Tércio Sampaio. Função social da dogmática jurídica. São Paulo: Max Limonad, 1998. Interpretação e estudos da Constituição de 1988. São Paulo: Atlas, 1990. Introdução ao estudo do direito: técnica, decisão, dominação. 4. ed. São Paulo: Atlas, 2003.

GADAMER, Hans-Georg. Gadamer in conversation: reflections and commentary. Translated by Richard Palmer. New Haven: Yale University Press, 2001. . Verdade e método. Petrópolis: Vozes, 2002. v. 2.

GRÄZIN, Igor. Law is myth. International Journal for the Semiotics of Law, Holanda, v. 18, n. 1, p. 23-51, Mar. 2005.

GRINOVER, Ada Pellegrini. O processo constitucional em marcha. 1. ed. São Paulo: Max Limonad, 1985.

HABERMAS, Jürgen. A nova intransparência: a crise do estado do bem - estar social e o esgotamento das snergias utópicas.. São Paulo: Centro Brasiliense de Análise e Planejamento, 1987. (Novos Estudos, n. 18).

HESSEN, Johannes. Filosofia dos valores. Tradução do Professor L. Cabral de Moncada (Universidade de Coimbra). 2. ed. corr. Coimbra: Coimbra Ed., 1953.

HUNGRIA, Nelson. Comentários ao Código Penal. Rio de Janeiro: Edições Revista Forense, 1955. v. 1, t. 1.

KALINOWSKI, Georges. Philosophie et logique d'interprétation en droit. Archives de Philosophie du Droit, Paris, v. 17, p. 39-49, 1972. 
KELSEN, Hans. Teoria pura do direito. Tradução João Batista Machado. São Paulo: Martins Fontes, 2003.

LAFER, Celso. A Constituição de 1988 e as relações internacionais: reflexões sobre o art. $4^{\circ}$. In: A internacionalização dos direitos humanos: constituição, racismo e relações internacionais. Barueru, SP: Manole, 2005.

. Direito e poder: apontamentos sobre o tema na reflexão de Miguel Reale. Revista da Faculdade de Direito da Universidade de São Paulo, São Paulo, v. 76, p. 203-221, 1981.

A internacionalização dos direitos humanos: constituição, racismo e relações internacionais. Barueru, SP: Manole, 2005.

. A internacionalização dos direitos humanos: o desafio do direito a ter direitos. Revista do Tribunal Regional Federal da $3^{a}$ Região, n. 75, p. 37-54, jan./fev. 2006.

Norberto Bobbio, Teoria do Ordenamento Jurídico. Revista da Pós-Graduação da Faculdade de Direito da USP, São Paulo, v. 2, p. 129-133, 2000.

Parecer. Caso Ellwanger: anti-semitismo como crime da prática do racismo. In: - A internacionalização dos direitos humanos: constituição, racismo e relações internacionais. Barueru, SP: Manole, 2005

A política e condição humana. Posfácio. In: ARENDT, Hannah. A condição humana. 10. ed. Tradução de Roberto Raposo Rio de Janeiro: Forense, 2005.

A reconstrução dos direitos humanos: a contribuição de Hannah Arendt. Estudos Avançados, São Paulo, v. 11, n. 30, 1997. [Dossiê Direitos Humanos].

A reconstrução dos direitos humanos: um diálogo com o pensamento de Hannah Arendt. 4. ed. São Paulo: Companhia das Letras, 2001.

LOCHAK, Danièle. Les droits de l'homme. Paris: La Découverte: 2005.

MACCORMICK, Neil. Legal reasoning and legal theory. Oxford: Claredon Press, 1997.

MARTINS, Samir José Caetano. Neoconstitucionalismo e seus reflexos no dever de fundamentação das decisões judiciais no Brasil. Revista Dialética de Direito Processual, São Paulo, n. 44, p. 101-120, nov. 2006. 
MEDICAL

Dictionary.

Disponível

em:

<http://www.medterms.com/script/main/art.asp?articlekey=6393>. Acesso em: 19 jul. 2009.

MELLO, Anthony. O canto do pássaro. Tradução de Hebert Salvador de Lima. São Paulo: Edições Loyola, 1982.

MURICY, Marília. Racionalidade do direito, justiça e interpretação: diálogo entre a teoria pura e a concepção luhmanniana do direito como sistema autopoiético. In: BOUCAULT, Carlos E. de Abreu; RODRIGUEZ, José Rodrigo (Orgs.). Hermenêutica plural: possibilidades jusfilosóficas em contextos imperfeitos. São Paulo: Martins Fontes, 2002. p. 103-125.

NEVES, António Castanheira. O actual problema metodológico da interpretação jurídica. Coimbra: Coimbra Ed., 2003. v. 1.

NEVES, Marcelo. A constitucionalização simbólica. São Paulo: Acadêmica, 1994.

OST, François. Júpiter, Hércules, Hermes: três modelos de juez. Trad. Isabel Lifante Vidal. Doxa: Cuadernos de filosofía del derecho, n. 14, p. 169-194, 1993.

PARINI, Pedro. O raciocínio dedutivo como possível estrutura lógica da argumentação judicial: silogismo versus entimema a partir da contraposição entre as teorias de Neil MacCormick e Katharina Sobota. In: CONGRESSO DO CONSELHO NACIONAL DE PESQUISA E PÓS-GRADUAÇÃO EM DIREITO, 14., 2006, Fortaleza. Anais... Florianópolis: Fundação Boiteux, 2006.

PIOVESAN, Flávia. Direitos humanos e justiça internacional. São Paulo: Saraiva, 2006.

Direitos humanos e o princípio da dignidade da pessoa humana, dos princípios constitucionais considerações em torno das normas principiológicas da Constituição. São Paulo: Malheiros, 2003.

PRADO, Lídia Reis de Almeida. O juiz e a emoção: aspectos da lógica da decisão judicial. Campinas: Millenium, 2003.

REALE, Miguel. Estudos de filosofia e ciência do direito. São Paulo: Saraiva, 1968.

A teoria da interpretação segundo Túlio Ascarelli. Revista de Direito Mercantil, Industrial, Econômico e Financeiro, São Paulo, v. 19, n. 30, p.75-85, abr./jun. 1980. 
REALE, Miguel. Teoria tridimensional do direito, teoria da justiça, fontes e modelos do direito. Lisboa: Imprensa Nacional Casa da Moeda, 2003. (Estudos Gerais, Série Universitária).

ROBLES, Gregório. Direito como texto: quatro estudos de teoria comunicacional do direito. Tradução de Roberto Barbosa Alves. Barueri: Manole, 2005.

RUSSELL, Bertrand. History of western philosophy. London: Routledge, 1996.

SALGADO, Joaquim Carlos. Princípios hermenêuticos dos direitos fundamentais. In: MOREIRA, Luiz; MERLE, Jean-Cristophe (Orgs.). Direito e legitimidade. São Paulo: Landy, 2003. p. 195-211.

SANTOS, Mario Ferreira dos. Métodos lógicos e dialéticos. 3. ed. São Paulo: Logos, 1959. v. 1.

SARLET, Ingo Wolfgang. Dignidade da pessoa humana e direitos fundamentais na Constituição Federal de 1988. Porto Alegre: Livraria do Advogado, 2001.

As dimensões da dignidade da pessoa humana: construindo uma compreensão jurídico-constitucional necessária e possível. Revista Brasileira de Direito Constitucional, São Paulo, n. 9, p. 361-388, jan./jul. 2007.

SEARLE, John. Minds, brains, and programs. Behavioral and Brain Sciences, n. 3, p. 417 $442,1980$.

SOBOTA, Katharina. Não mencione a norma! Tradução João Maurício Adeodato. Anuário dos Cursos de Pós-Graduação em Direito, Recife, n. 7, p. 251-273, 1995.

WANG, Daniel Wei Liang. Escassez de recursos, custos dos direitos e reserva do possível na jurisprudência do Supremo Tribunal Federal. 2006. (Monografia) - Sociedade Brasileira de Direito Público, São Paulo, 2006.

WEBER, Max. Economia e sociedade: fundamentos da sociologia compreensiva. Tradução de Regis Barbosa e Karen Elsabe Barbosa. 4. ed. Brasília: Ed. da UnB, 2000. v. 1.

ZAGREBELSKY, Gustavo. El derecho dúctil: ley, derechos, justicia. Trad. de Marina Gascón. 7. ed. Madrid: Trotta, 2007. 